
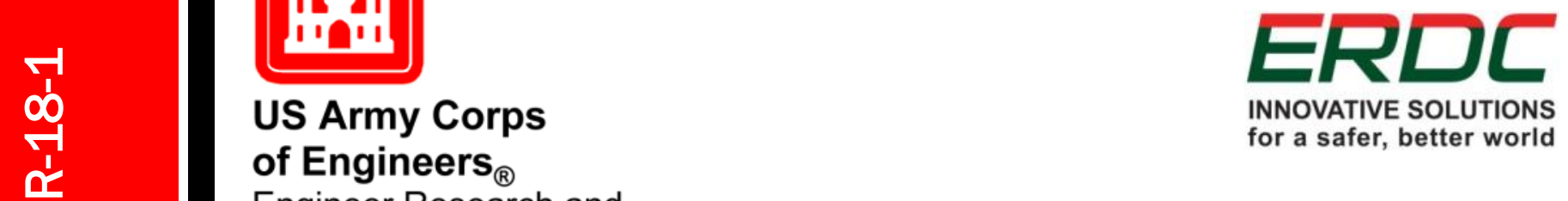

INNOVATIVE SOLUTIONS

for a safer, better world

Engineer Research and

Development Center

Center for the Advancement of Sustainability Innovations (CASI)

\title{
Sustainability-Related Publications Calendar Years 2016 - 2017
}

Franklin H. Holcomb, Patrick N. Deliman, and David B. Ringelberg

April 2018
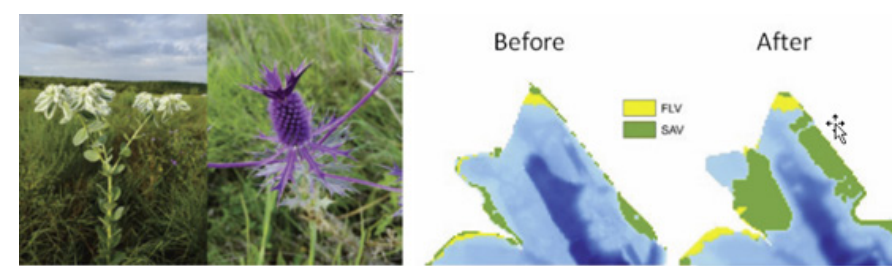

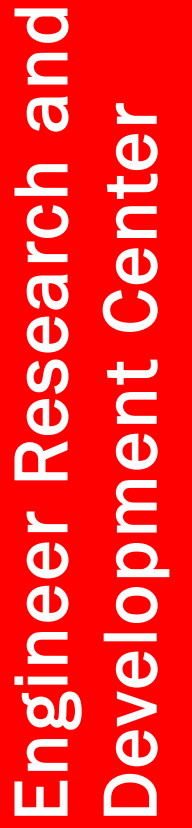
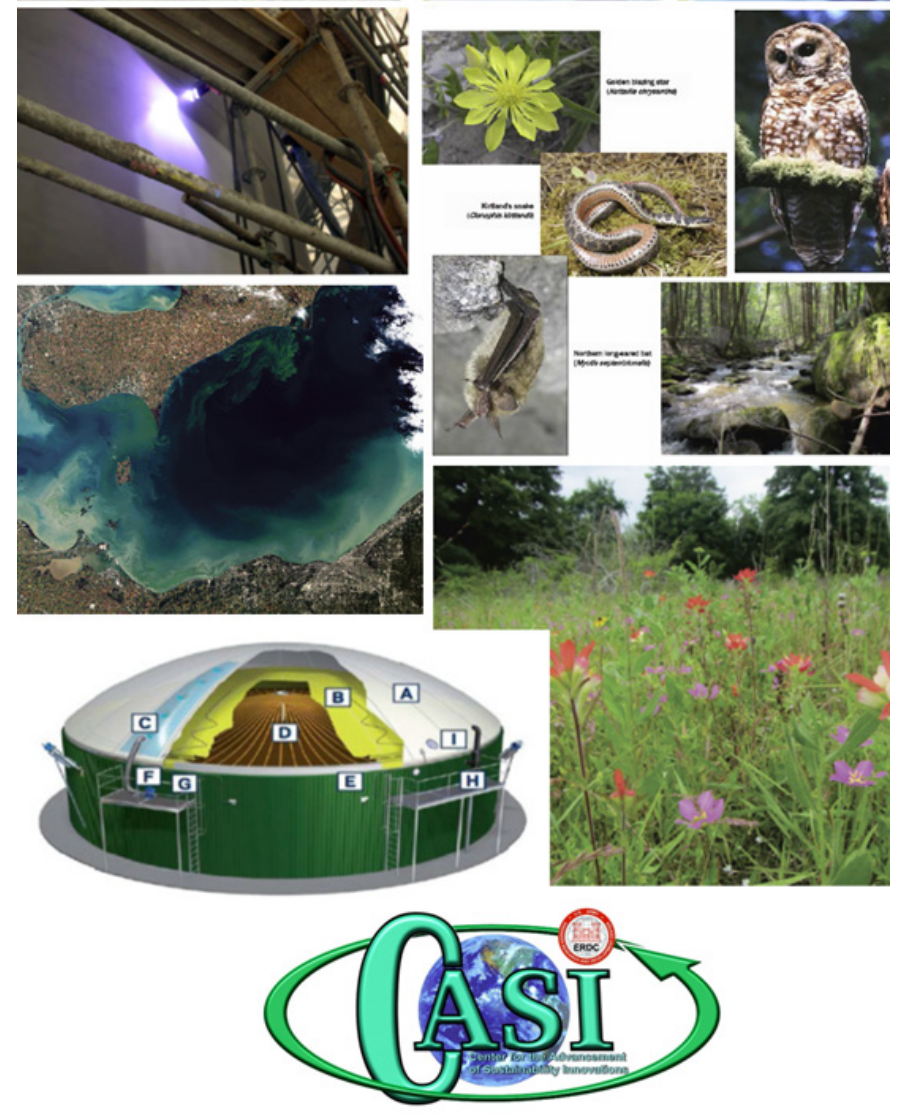

Approved for public release; distribution is unlimited. 
The U.S. Army Engineer Research and Development Center (ERDC) solves the nation's toughest engineering and environmental challenges. ERDC develops innovative solutions in civil and military engineering, geospatial sciences, water resources, and environmental sciences for the Army, the Department of Defense, civilian agencies, and our nation's public good. Find out more at www.erdc.usace.army.mil.

To search for other technical reports published by ERDC, visit the ERDC online library at http://acwc.sdp.sirsi.net/client/default. 


\section{Sustainability-Related Publications Calendar Years 2016 - 2017}

Franklin H. Holcomb

U.S. Army Engineer Research and Development Center (ERDC)

Construction Engineering Research Laboratory (CERL)

2902 Newmark Dr.

Champaign, IL 61824

Patrick N. Deliman

U.S. Army Engineer Research and Development Center (ERDC)

Environmental Laboratory (EL)

Waterways Experiment Station, 3909 Halls Ferry Road

Vicksburg, MS 39180-6199

David B. Ringelberg

U.S. Army Engineer Research and Development Center (ERDC)

Cold Regions Research and Engineering Laboratory (CRREL)

72 Lyme Road

Hanover, NH 03755-1290ress

Final Report

Approved for public release; distribution is unlimited.

Prepared for Center for the Advancement of Sustainability Innovations (CASI) 


\section{Abstract}

The Center for the Advancement of Sustainability Innovations (CASI) was established by the U.S. Army Engineer Research and Development Center (ERDC) as a new capability in 2006 hosted at the Construction Engineering Research Laboratory (CERL) in Champaign, IL. CASI was established with the goal of focusing the value of ERDC expertise, technologies, and partnerships toward helping the U.S. Army Corps of Engineers (USACE), the Army, and the Department of Defense (DoD) achieve more sustainable facilities and operations. CASI provides the military with capabilities that enhance national security by more effectively using limited resources and improving coordination and partnerships with host communities and stakeholders in the United States and around the globe. CASI teams strive to measure sustainability innovations against the Triple Bottom Line of mission, environment, and community. CASI focuses on cost savings, innovation, collaborative solutions, and continuous learning-which directly link sustainability to Army policy and guidance documents including Army Installations 2025; Installations, Energy and Environment Strategy 2025; Army Environment, Safety, \& Occupational Health Strategy 2025; and Energy Security and Sustainability $\left(\mathrm{ES}^{2}\right)$ Strategy. Note that this "summary of sustainability-related publications" incorporates descriptions of work related to the theme of sustainability conducted under many ERDC programs as well as CASI.

DISCLAIMER: The contents of this report are not to be used for advertising, publication, or promotional purposes. Citation of trade names does not constitute an official endorsement or approval of the use of such commercial products. All product names and trademarks cited are the property of their respective owners. The findings of this report are not to be construed as an official Department of the Army position unless so designated by other authorized documents. 


\section{Contents}

Abstract ii

Preface iv

1 Introduction $\quad 5$

2 Anticipating Emerging Issues 10

3 Climate-Driven Risks to Natural and Built Environments 15

4 Sustainable Installations - Net-Zero Planning 23

5 Sustainable Energy Solutions 24

6 Sustainable Water \& Waste Resources 27

7 Sustainable Facilities and Infrastructure $\quad 35$

8 Sustainable Contingency Basing 56

9 Sustainable Natural Infrastructure $\quad 61$

10 Green Remediation and Reuse 77

11 Acronyms and Abbreviations $\quad 89$

12 Included Documents 93

$\begin{array}{ll}\text { Report Documentation Page (SF 298) } & 96\end{array}$ 


\section{Preface}

This work was performed under the Center for the Advancement of Sustainability Innovations (CASI). CASI was established by the U.S. Army Engineer Research and Development Center (ERDC) as a new capability in 2006, hosted at the ERDC Construction Engineering Research Laboratory (CERL) in Champaign, IL. CASI's mission is to focus ERDC expertise, technologies and partnerships toward helping the U.S. Army Corps of Engineers (USACE), the Army, and the Department of Defense (DoD) achieve more sustainable missions, facilities, and operations. The technical monitor and Associate Director of CASI was Franklin H. Holcomb. Dr. Patrick Deliman of the ERDC Environmental Laboratory (EL) and David Ringelberg of the ERDC Cold Regions Research and Engineering Laboratory (CRREL) were Advisory Board members of CASI.

At the time of publication, Alan Anderson (CEERD-CZT) was the CERL Technical Director for Military Ranges and Lands and Dr. Patrick N. Deliman (CEERD-EVE) was the EL Technical Director for Environmental Modeling and Assessment. David B. Ringelberg is a Research Microbiologist and Associate Technical Director, Environmental Quality and Installations, Office of the Technical Director, CRREL (CEERD-RRN). The Interim Deputy Director of ERDC-CERL was Michelle Hanson and the Interim Director was Dr. Kirankumar Topudurti; the Deputy Director of ERDC-EL was Dr. Jack E. Davis and the Director was Dr. Beth C. Fleming; the Deputy Director of ERDC-CRREL was Dr. Joseph L. Corriveau and the Director was Dr. Lance D. Hansen.

COL Bryan S. Green was Commander of ERDC, and Dr. David W. Pittman was the Director. 


\section{Introduction}

\section{Background}

The Center for the Advancement of Sustainability Innovations (CASI) was established by the U.S. Army Engineer Research and Development Center (ERDC) as a new capability in 2006, hosted at the Construction Engineering Research Laboratory (CERL) in Champaign, IL. CASI's mission is to focus ERDC expertise, technologies and partnerships toward helping the U.S. Army Corps of Engineers (USACE), the Army, and the Department of Defense (DoD) achieve more sustainable missions, facilities, and operations. CASI provides the military with capabilities that enhance national security through more effective use of limited resources and improved coordination and partnerships with host communities and stakeholders in the United States and across the globe.

In all efforts, CASI teams strive to measure sustainability innovations against the Triple Bottom Line of mission, environment, and community. In addition, CASI focuses on cost savings, innovation, collaborative solutions, and continuous learning, all of which directly link sustainability to Army policy and guidance documents including Army Installations 2025; Installations, Energy and Environment Strategy 2025; Army Environment, Safety, \& Occupational Health Strategy 2025; and Energy Security and Sustainability (ES') Strategy (https://www.army.mil/asaiee\#torg-resources).

This 2016-2017 Sustainability-Related Publications is the ninth annual CASI publication. Previous annual publications, published from 2008-16, are referenced below, with links provided to the documents (all of which are also located on the CASI website under the "Library" section).

Sustainability-Related Publications Calendar Years 2015 - 2016, Franklin H. Holcomb, Patrick N. Deliman, and David B. Ringelberg, ERDC SR-17-2, June 2017, http://dx.doi.org/10.21079/11681/22666

Sustainability-Related Publications Calendar Years 2014-2015, Alan B. Anderson, Franklin H. Holcomb, Annette Stumpf, Elon Zeigler, Patrick N. Deliman, and Kevin Knuuti, ERDC/CERL TN-16-2, March 2016, http://acwc.sdp.sirsi.net/client/search/asset/1049647

CASI Work Plan Calendar Year 2014, Alan Anderson, Franklin Holcomb, Annette Stumpf, and Elon Zeigler, ERDC/CERL TN-14-1, June 2014, http://acwc.sdp.sirsi.net/client/en_U.S./search/asset/1036586 
CASI Work Plan Calendar Year 2013, William D. Goran, Michelle Hanson, Elon Zeigler, and Annette Stumpf, ERDC/CERL TN-13-1, http://acwc.sdp.sirsi.net/client/search/asset/1025640 https://eko.usace.army.mil/_secure/4BEEA029-E2E0-0960748272F8F7EF/ERDC-CERL_TN13-1.pdf

CASI Work Plan Calendar Year 2012, William D. Goran, Michelle Hanson, Elon Zeigler, and Annette Stumpf, ERDC/CERL TN-12-1, January 2012, https://eko.usace.army.mil/_secure/4BDCC685-B81D-1CD13D958CFDE2DB11C5/2012WorkPlan-13-Jan-FINAL-smallfile.pdf

Center for Advancement of Sustainability Innovations: 2011 Work Plan, William Goran, et al., ERDC/CERL TN-11-11, January 2011, https://eko.usace.army.mil/centers/casi/library/?syspage=Documents\&id=263037

Center for Advancement of Sustainability Innovations: 2010 Work Plan, William Goran, et al., ERDC/CERL TN-10-1, April 2010, at either: https://eko.usace.army.mil/_secure/4B7DD77A-C376-36A8A84FEC6F7A1DC3BE/FY_2010_CASI_Work_Plan.pdf https://eko.usace.army.mil/centers/casi/library/?syspage=Documents\&id=263155

CASI Work Plan Fiscal Year 2009, William Goran, Annette Stumpf, and Michelle Hanson, ERDC/CERL Special Report 08-21, November 2008, https://eko.usace.army.mil/_secure/4BA5065B-E946-50E120324297E3099A62/Work_PlanFINALMay1509_\%282\%29.pdf

Fiscal Year 2007 Annual Report, Center for the Advancement of Sustainability Innovations, William Goran, ERDC/CERL Technical Note (TN-08-02), May 2008, (CASI Work Plan for 2008), http://acwc.sdp.sirsi.net/client/search/asset/1002025

\section{Objective}

The purpose of this series of summary documents has been to:

- Provide a framework to capture diverse sustainability activities being conducted by ERDC

- Help various sponsors, partners and stakeholders understand the scope of sustainability activities and expertise that ERDC can offer

- Identify areas where activities can be leveraged for those with similar interests or ongoing investments

- Suggest potential research areas that have been conceived but not yet resourced by potential partners and sponsors

- Enhance dialog and teaming across the different technical focus areas

- Document ERDC sustainability activities.

Of special note is the inclusive nature of this "summary of sustainabilityrelated publications," which incorporates descriptions of work related to 
the theme of sustainability that was conducted under many ERDC programs as well as CASI.

\section{Approach}

\section{Technology Focus Areas}

One of the key values of CASI is to provide "systems level" expertise to address complex sustainability issues. Installations and communities engage across a wide range of economic, environmental, social, and mission issues that interact in multiple temporal and spatial dimensions. Most of the issues addressed in this document span multiple technology focus areas. The focus areas are simply useful "bins" for planning suites of projects and joining groups of experts. These technology focus areas also indicate the explicit topical areas where CASI has selected teams of experts from within and beyond ERDC. As the sustainability challenges of the U.S. military change, these technology focus areas will also change. Currently, the nine CASI technology focus areas are:

- Anticipating Emerging Issues

- Climate-Driven Risks to Natural and Built Environments

- Sustainable Installations - Net Zero Planning

- Sustainable Energy Solutions

- Sustainable Water \& Waste Resources

- Sustainable Facilities and Infrastructure

- Sustainable Contingency Basing

- Sustainable Natural Infrastructure

- Green Remediation and Reuse.

\section{Coordination and Outreach}

\section{Website}

The CASI website is supported by the Engineering Knowledge Online $\left(\mathrm{EKO}{ }^{\circledR}\right.$ ) portal: https://eko.usace.army.mil/centers/casi/

The website includes a calendar of events, information on each of the technology focus areas, a library with all available CASI documents and publications, and links to other related sites. Several CASI technology focus areas manage additional web resources supplementing the information on CASI's website, with links from the CASI website. 


\section{Marketing Materials}

The CASI brochure and poster are available for download on the CASI website. A CASI display supports marketing activities at conferences, job fairs, and other venues.

\section{Electronic Copies}

Electronic copies of the CASI annual publications are available at: https://eko.usace.army.mil/centers/casi/library/

\section{Partnerships}

CASI strives to bring the best team to any specific challenge and this often involves the creation of unique partnerships for each project. CASI has formal and informal partnership arrangements with many academic, industry, and government organizations. Many of the descriptions of these sustainability-related publications highlight these partner organizations.

\section{Projects Represented in This Publications Summary}

The summary is an important tool for CASI to share information and create dialog across multiple stakeholders and organizations. While CASI/Sustainability projects are usually funded by individual sponsors, most projects are also of interest to other sponsors. This summary allows for all sponsors to learn about and follow the progress of any project or area of interest, and where appropriate, to acquire access to project outcomes. In addition, a project sponsored by one organization may help create the dialog necessary to initiate a related or follow-on effort tailored to another organization.

This summary focuses on completed projects. Projects discussed in this report were finished during calendar years 2015-16. While each project is identified within a specific technology focus area, many of these projects are relevant across multiple technology focus areas. The immediate outcomes could be a service (e.g., a new web capability), a forum (e.g., the Interagency Climate Change Impacts and Adaptations forum sessions), a demonstration of a capability, and/or a publication. However, for many CASI/Sustainability initiatives, long-term outcomes are improved understanding of system relationships and tradeoffs, and/or the identification of new pathways to achieve more efficient and sustainable military operations. 


\section{CASI Leadership}
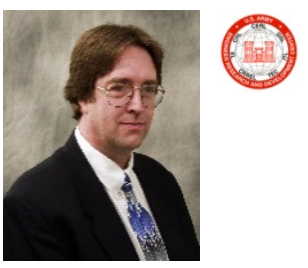

Alan B. Anderson CASI Director 217-373-7233

Alan.B.Anderson@usace.army.mil
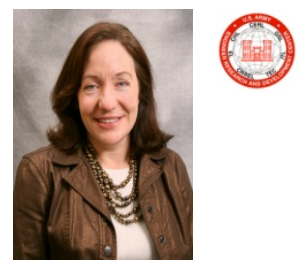

Annette L. Stumpf Installation Outreach

217-373-4492

Annette.L.Stumpf@usace.army.mil

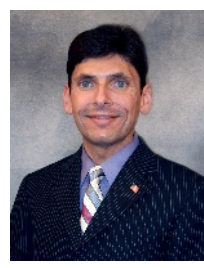

Franklin H. Holcomb CASI Associate Director 217-373-5864

Franklin.H.Holcomb@usace.army.mil

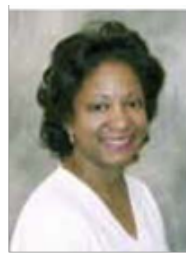

Elon P. Zeigler Knowledge Management Representative

217-373-7256

Elon.P.Zeigler@usace.army.mil

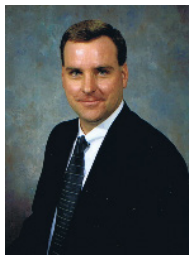

Patrick N. Deliman CASI Advisory Board 601-634-3623

Patrick.N.Deliman@usace.army.mil

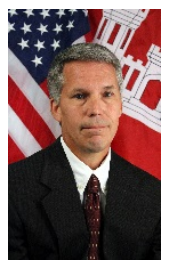

David B. Ringelberg CASI Advisory Board (603) 646-4744 David.B.Ringelberg@usace.army.mil 


\section{Anticipating Emerging Issues}

This focus area strives to achieve a threefold purpose, to: (1) engage stakeholders through forums, white papers, publications and other means about emerging issues of concern, (2) interpret how these emerging issues might impact defense activities and operations, and (3) initiate a dialog about potential courses of action to respond to these issues. The CASI White Paper series is one forum that accomplishes this purpose.

Giselle Rodriguez, Dominique Gilbert, LTC M. Zillur Rahman, Jorge Flores, Peter Stynoski, Cate Fox-Lent, and Igor Linkov. 2017. ERDC SR-17-1. Material Life Cycle Analysis for the Reduction of Waste Generation at Military Installations, http://dx.doi.org/10.21079/11681/22601

In 2011, the U.S. Army implemented the Net Zero Initiative, which includes Net Zero Energy, Net Zero Water and Net Zero Waste (NZW). A NZW installation is an installation that reduces, reuses, and recovers waste streams by converting them to resource value without using a landfill. To assist in that effort, this work reviewed the policies and initiatives aimed at reduction waste generation, discussed the challenges on the implementation of improvement efforts, and outlined existing research and operational needs to support more efficient operations and the achievement of Net Zero goals.

MacAllister, Irene E., Jinelle H. Sperry, and Pamela Bailey. 2016. ERDC TN-16-1. Identification of Insect-Plant Pollination Networks for a Midwest Installation: Fort McCoy, WI, http://acwc.sdp.sirsi.net/client/en_US/search/asset/1049246

Pollinating insects and pollinator dependent plants are critical components of functioning ecosystems, yet for many DoD installations, the identities and relationships between pollinators and plants are unknown. This study demonstrated methods for compiling and analyzing readily available information for insect pollinators and pollination dependent plants for a single installation, Fort McCoy, WI. Although installation documents identified a total of 1470 insect species and 972 plant species were identified on the installation, this work focused on species of conservation concern (nine pollinator insect species and three pollinator-associated plant species). Published information on insect pollinators and pollination dependent plants was then used to conduct a basic plant-pollinator network analyses using free analytical network software (software package R), which revealed that all the plant species of conservation concern are pollinated 
by several insect pollinator species. However, many pollinator insect species of conservation concern were associated with a limited number of host plant species. The results of this work suggest that analyses that rely on publicly available information provide a useful starting point in determining basic, binary plant-pollinator relationships. Field-collected data, e.g., frequency of pollinator-plant interactions, would be required for a more detailed, robust network analysis. Results of the insect pollinators bipartite mutualistic network analysis. Pollinators are indicated with brown boxes and plants species are in green.

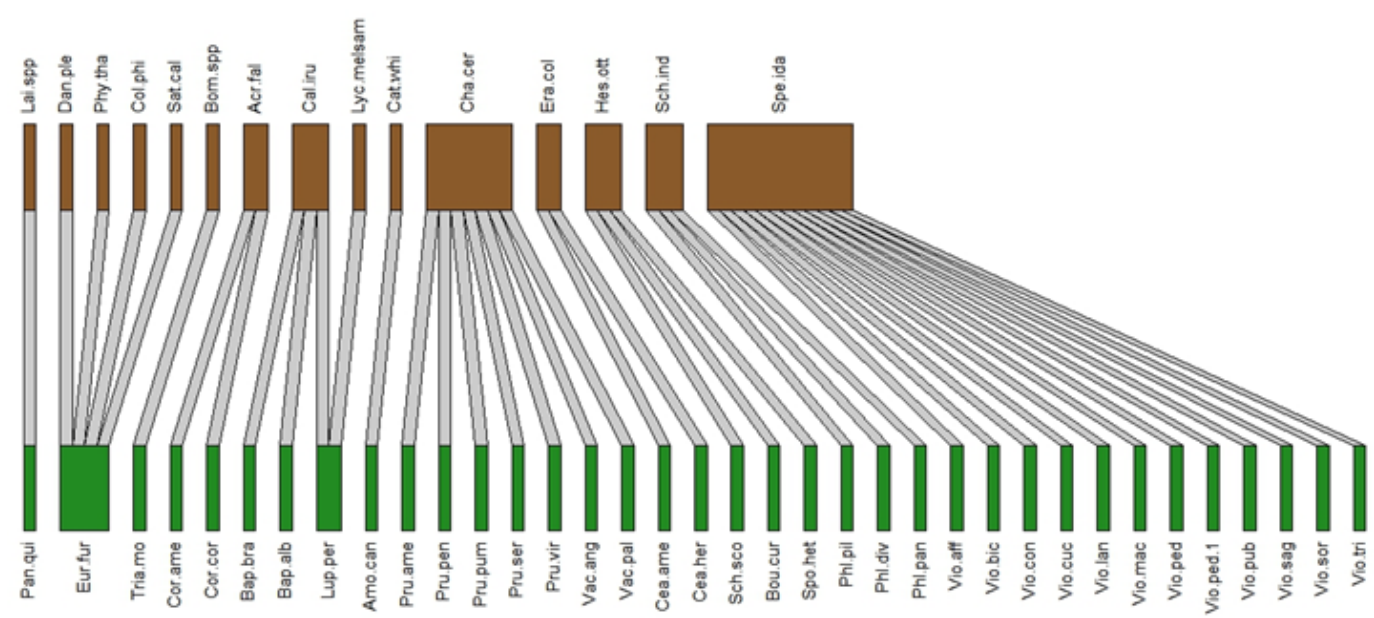

Ping Gong. 2017. ERDC/EL SR-17-2. Invasive Species Management on Military Lands: Clustered Regularly Interspaced Short Palindromic Repeat/CRISPR-associated protein 9 (CRISPR/Cas9)-based Gene Drives, http://dx.doi.org/10.21079/11681/22721

Applications of genetic engineering-based technologies to the control of invasive species are emerging as an important area of innovation. As a mechanism to spread the desired genes and associated traits into the target population, gene drive is recognized as a promising genetic biocontrol strategy to combat invasive species. Unlike existing technologies that depend on the cumbersome custom-making of new proteins for each deoxyribonucleic acid (DNA) target, the CRISPR system uses ribonucleic acid (RNA) as its DNA-homing mechanism, which makes it low cost, high efficiency, easy to implement, and dramatically shortens the design-build-test cycle for gene drive development. The CRISPR/Cas9 technology can alter multiple loci at the target gene that prevent mutations from blocking the spread of the drive. It can also be used to develop multiple types of gene drives such as precision, immunization, and reversal drives to precisely target a specific subpopulation, protect a population from any future gene 
drive "invasions", and overwrite previously released drives in case of unanticipated effects, respectively. Poised to become a self-sustaining, highly efficient, environmentally benign, and cost-effective alternative for invasive species control, CRISPR/Cas9-mediated gene drives can sweep a "deleterious" gene through a population exponentially faster than the normal Mendelian in-heritance, and thus suppress or eradicate the target invasive species.

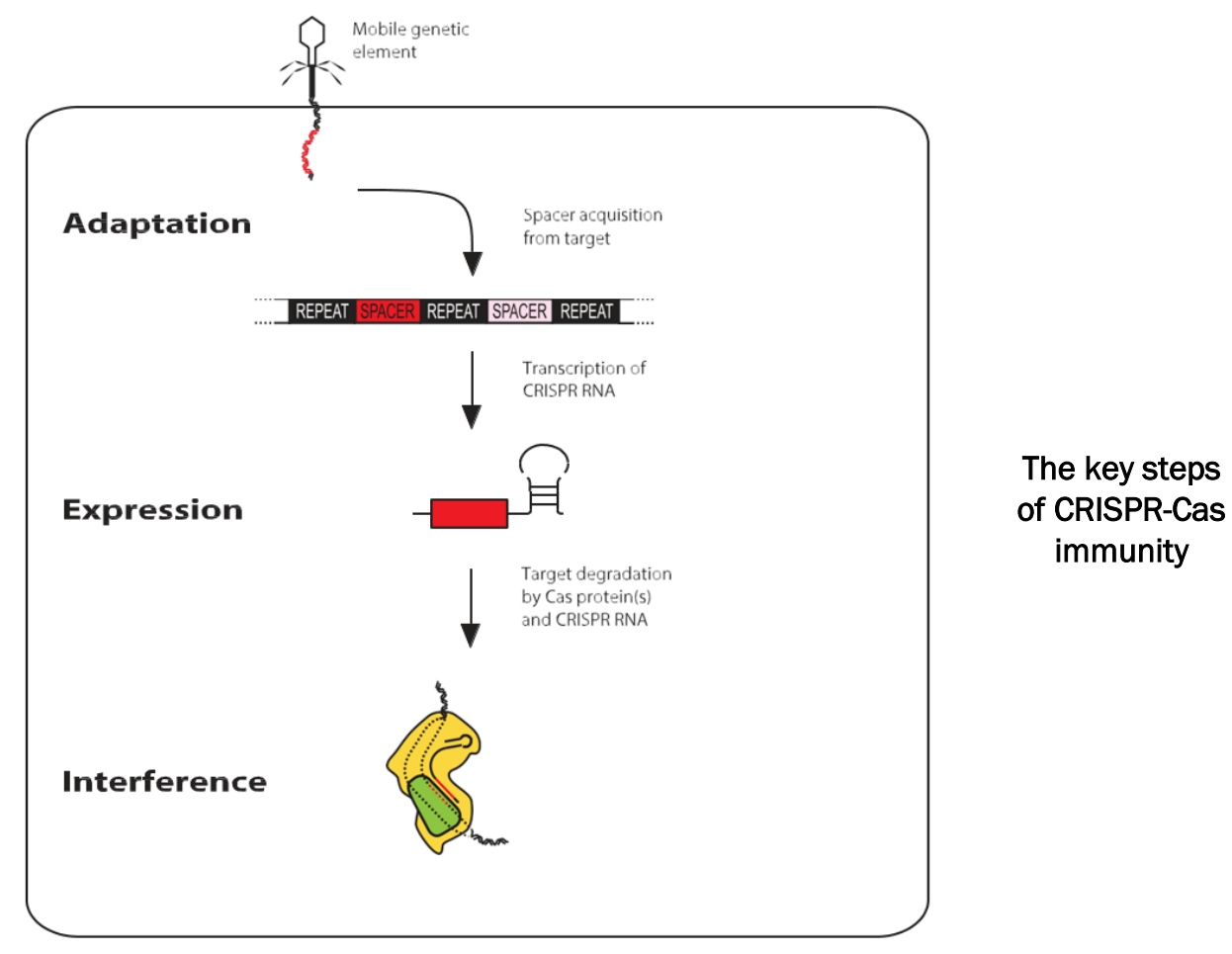

While relying on exactly the same copying/homing mechanism as naturally existing homing endonucleases, CRISPR/Cas9-mediated gene drives can sweep a "deleterious" gene through a population exponentially faster than normal Mendelian inheritance, thus suppressing or eradicating the target invasive species. CRISPR/Cas9-based gene drives are poised to become a self-sustaining, highly efficient, environmentally benign, and cost effective alternative for invasive species control. Biosafety, ecological risks, regulations, public perceptions, and limitations surrounding the development and release of CRISPR/Cas9-based gene drives are also discussed. 
Dawn A. Morrison, Colin D. Wood, Timothy K. Perkins, et al. 2016. ERDC/CERL SR-16-3. Extreme Environment Basing: Contingency Basing in Dense Urban and Megacity Environments, https://erdc-library.erdc.dren.mil/xmlui/bitstream/handle/11681/21471/ERDC-CERL\%20SR-163\%20Dist\%20A.pdf? sequence $=1$ \&isAllowed $=y$

The U.S. military may be required to operate in dense urban and megacity environments, which may pose significant challenges for contingency basing. This work reviews and analyzes the potential disconnect between existing doctrine, standard operating procedures, and the human geographic reality of dense urban environments and megacities as concerns contingency basing. The work: (1) characterizes 41 projected megacities using the Army Chief of Staff's Strategic Study Group's megacity typology, (2) performs crosswalk analysis between this characterization and existing contingency basing doctrine, (3) details doctrinal gaps, specifically those pertaining to site selection, logistics, and security, and (4) recommends future research to alleviate those gaps.

Dense urban environments, top-left, clockwise: favelas of Rio de Janeiro; traffic in Dhaka, Bangladesh; residential area of downtown Hong Kong; Slums surrounding the Mumbai International Airport.
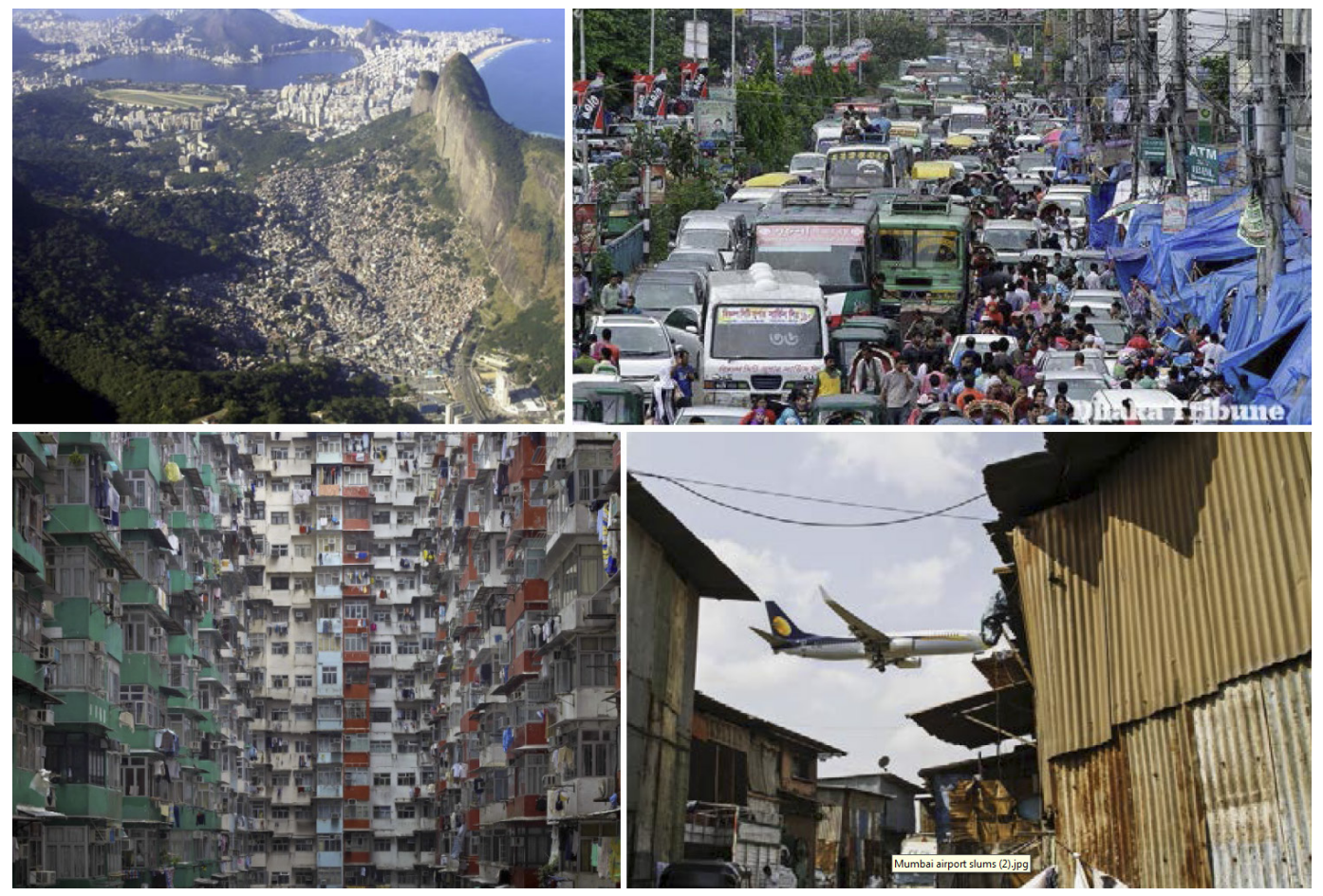
David Delaney, Patrick Guertin, Michael White, et al. 2016. ERDC-CERL TN-161. Assessment of Small Arms Munitions Impacts on Natural Infrastructure in Sensitive Downrange Areas on Military Installations, http://acwc.sdp.sirsi.net/client/en_US/search/asset/1048789

Large areas of high quality terrestrial natural infrastructure exist downrange of small arms training ranges on DoD installations. Live-fire training has caused concern to regulatory entities due to the potential impacts on natural resources, and to safety concerns expressed by adjoining land owners. This paper investigated whether there are reliable documented methods to quantify the number of bullets that escape the cantonment berm and ultimately fall down range via queries among Natural Resource peers and a technology review to document existing methods that address bullet fate on ranges.

Responses to the inquiries indicate that Natural Resource personnel on military facilities or other state or Federal agencies do not have adequate tools or guidance to address the potential issue of smalls arms munition impacts within sensitive downrange areas. It was recommended that military installations further examine acoustical techniques for quantifying bullet overshot and ricochets into sensitive wildlife areas. Acoustical techniques offer a viable method for quantifying bullet intrusions into downrange areas. However, a more comprehensive testing procedure must be tested to gauge the effectiveness of this technique at bermed and unbermed ranges under different field conditions.
Different types of tree damage caused by bullet strikes on Fort Benning and Fort Stewart, GA: small scars (A), large cambium cuts (B), bark bullet strikes (C), nodules (D), and broken branches, leader or stems (E).

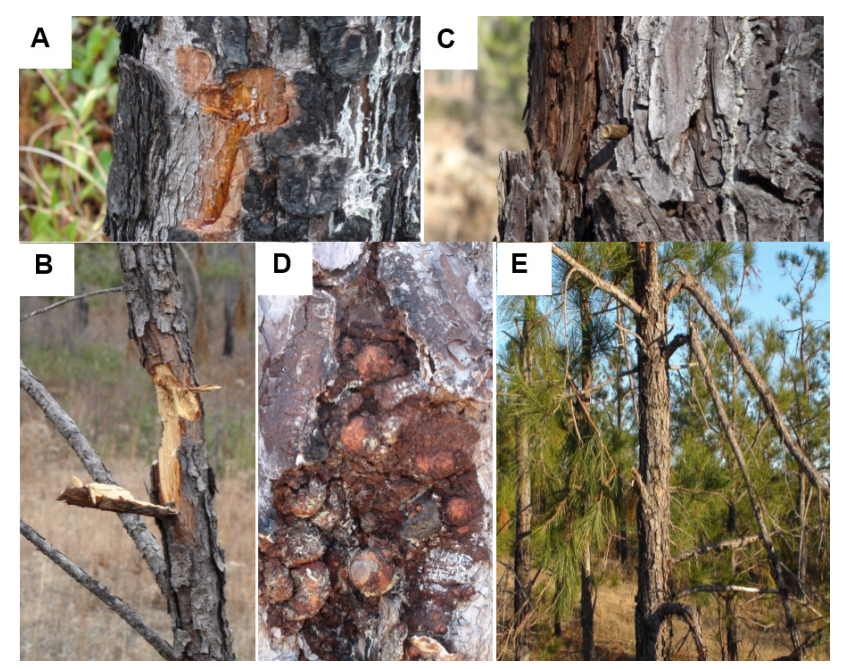




\section{Climate-Driven Risks to Natural and Built Environments}

Climate change is one future trend that will impact our national security. Rising global temperatures, changing precipitation patterns, climbing sea levels, and more extreme weather events will intensify the challenges of global instability, hunger, poverty, and conflict. Climate change is seen as a "threat multiplier" because it has the potential to exacerbate many of the challenges facing the Nation today - from infectious disease to terrorism. A changing climate will have real impacts on our military and on the way it executes its missions, on the way it is called upon to support civil authorities and to provide humanitarian assistance and disaster relief in the face of more frequent and more intense natural disasters.

This focus area addresses the challenges of changing climatic and related conditions. Challenges include those associated with facilities, lands, and operations, and the stressors, posed by changing climatic conditions, on regional and national stability across the globe. Activities in this focus area involve several partnerships with other agencies and nations.

Matthew G. Hohmann. 2017. ERDC/CERL TR-17-25. Evaluation of Methods for Assessing Vulnerability of Army Installations to Impacts of Climate Change on Listed and At-Risk Species, http://dx.doi.org/10.21079/11681/22772

Environmental factors have received only limited attention as part of past Base Realignment and Closure (BRAC) decision-making processes, and climate-change impacts have not yet been considered. During BRAC 2005, the Army considered listed and at-risk species as part of its environmental- criterion analysis. These species affect BRAC analyses given that their status can lead to restrictions on training land use, and that such restrictions are likely to increase under future rules addressing climate change. The objectives of this work were to identify prospective approaches for assessing the vulnerability of installations to climate-change impacts on listed and at-risk species, and to evaluate their suitability for informing BRAC-related evaluations. Three recently developed methods for assessing the vulnerability of Army installations to impacts of climate change on

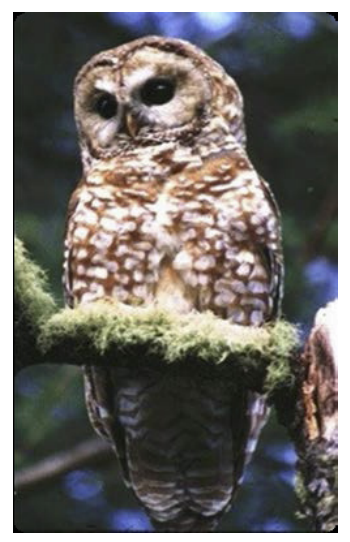


listed and at-risk species were evaluated using the SMART (Specific, Measurable, Attainable, Realistic, and Timely) decision analysis framework. Each method was rated against the SMART criteria and an aggregate score was provided. The assessment approach having the maximum aggregate score was recommended as likely suitable for informing future BRAC and restationing evaluations. It characterizes installation and regional climate change vulnerability by integrating multiple factors related to exposure, sensitivity, adaptive capacity, and number of listed and at-risk species.

Matthew G. Hohmann. 2017. ERDC/CERL TR-17-22. Climate Change VuInerability of Army Installations Attributable to Listed and At-Risk Species, http://dx.doi.org/10.21079/11681/23957

Climate change is an important emerging concern for DoD and the Army. Key among the issues is climate change-driven increases in the number of species listed under the U.S. Endangered Species Act (ESA) and stress to Federally listed species already listed, because both pose additional management requirements and challenges, as well as potential restrictions on training land use. This work developed an approach for characterizing this component of installation cli-mate change vulnerability that integrates multiple factors related to expo-sure, sensitivity, adaptive capacity, and number of listed and at-risk species. The approach was applied to Army installations in the Continental United States that have Integrated Training Area Management (ITAM) programs. Additionally, the assessment was used to rank installations across the Army based on the aggregate vulnerabilities of species. The approach to vulnerability assessment demonstrated here is suitable for evaluating whether climate change-driven impacts to listed and at-risk species is likely to affect installation resilience.

Matthew G. Hohmann. 2017. ERDC/CERL TR-17-21. Multiscale Assessment of Listed and At-Risk Species' Climate Change Vulnerabilities, http://dx.doi.org/10.21079/11681/23814

Climate change is of concern to the U.S. Department of Defense because climate change-driven increases in the number of species Federally listed under the U.S. Endangered Species Act (ESA) and stress to listed species can lead to additional requirements and potential restrictions on training land use. A first step in guiding management strategies to promote climate change adaptation is to assess species' vulnerabilities. However, vulnerability assessments conducted at a single scale or for arbitrary regions offer limited information to guide management decisions. This work developed 
and demonstrated an approach for multiscale species vulnerability assessments that integrates weighted estimates of range-wide and local vulnerability, and vulnerability on Federal land, where species' occurrence often influences ESA listing decisions. The approach was applied to 16 plant and animal species on five regionally representative Army installations. The assessments were used to rank species based on their occurrence on multiple installations across the Army and to rank the five study installations based on aggregate species' vulnerabilities. This approach is suitable for integrating climate change considerations into installation Integrated Natural Resource Management Plans, for evaluating whether climate change-driven impacts to listed species will affect installation resilience, and for identifying potential conservation partners among Federal land managers.

\section{Scott A. Tweddale. 2017. ERDC/CERL TN-17-2. Use of Heating and Cooling Degree Days to Project Relative Changes in Heating and Cooling Costs In Response to Climate Change on Selected Army Installations, http://dx.doi.org/10.21079/11681/26648}

This work demonstrated a method to calculate heating and cooling degree days for future time periods based on projected mean temperatures from Global Circulation Models (GCMs). This method provides a rudimentary capability to estimate relative increases/decreases in heating and cooling costs on military installations. Projected mean monthly climate data (1/8-degree BCSDCMIP $5{ }^{*}$ Climate Monthly Projections) for each of nine representative GCMs and for emission scenarios RCP2.6 and RCP8.5 were calculated Continental United States (CONUS) wide for four different epochs. Using the R statistical package, an automated method for calcu-

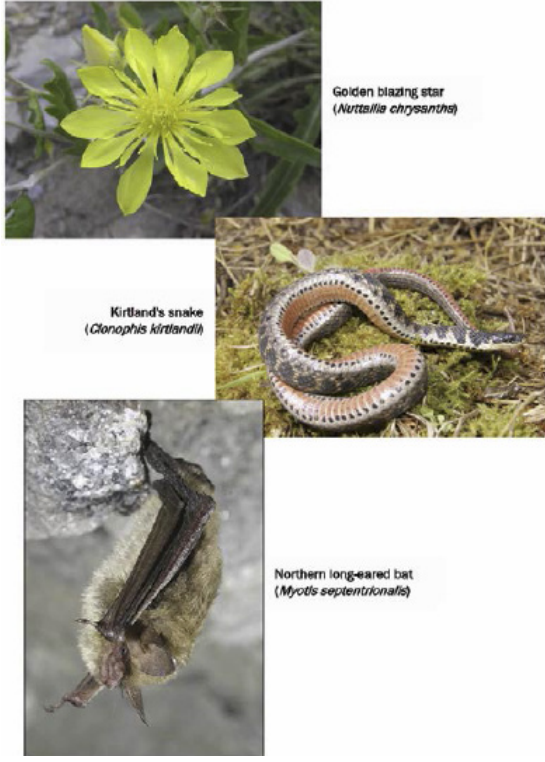

Representative species from Fort Carson, $\mathrm{CO}$ and Camp Atterbury, IN, which have the highest estimated climate change exposure among installations estimated to have high climate change vulnerability. lating mean monthly temperature for the four different epochs for each GCM and representative concentration pathway (RCP) emission scenario was demonstrated for an installation case study (Fort Benning, GA). Mean

* Bias-Corrected Statistical Downscaling-Coupled Model Intercomparison Project Phase 5 
monthly temperature data were then used as input to heating and cooling degree day calculations and summed to calculate an annual estimate of total heating and cooling degree days for each GCM, RCP, and epoch at Fort Benning, GA. The methods demonstrated could be applied CONUS-wide to estimate projected increases or decreases in heating and cooling degree days for any given location, including any DoD training installation.

Wade Wall. 2016. ERDC TR-16-1. Effects of Climate Change and Urban Development on Army Training Capabilities: Firing Ranges and Maneuver Areas, http://acwc.sdp.sirsi.net/client/en_US/search/asset/1054587

Army stationing analyses have historically been conducted under the assumption that most conditions at and around installations will generally remain static. Previous optimal stationing analyses have resulted in substantial costs associated with moving units, constructing buildings and roads, and local investments in the development of off-post housing, shopping facilities, eating, and other businesses that provide quality of life for soldiers and their families. In reality, the capacity of the natural, social, and built infrastructure changes over time,

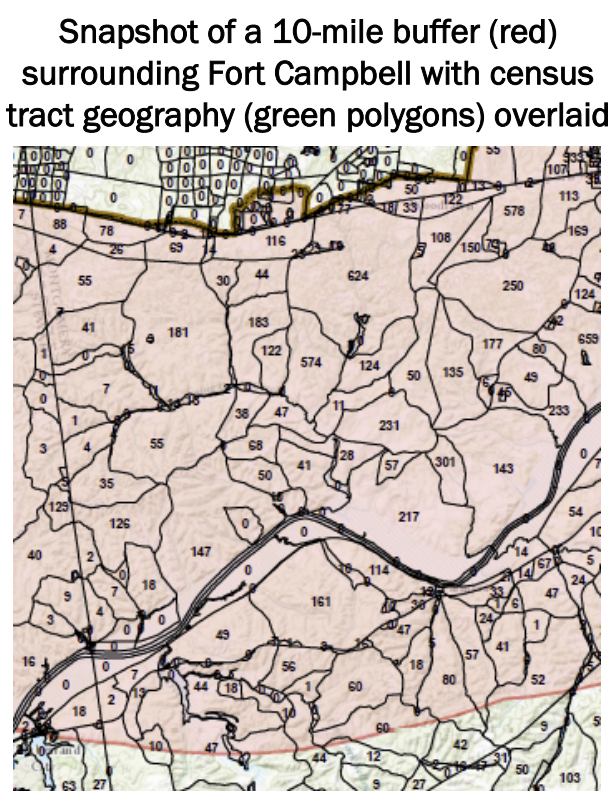
and, this non-stationarity should be considered in stationing analyses to: (1) avoid premature abandonment of expensive buildings and associated infrastructure, and (2) avoid costly realignments to locations where capacity is being adversely affected by change. This work documents efforts completed in Fiscal Year 2014 (FY14) that began to investigate how potential changes associated with climate and urban development might affect the ability of Army installations to continue to conduct training on firing ranges and in maneuver areas.

Michelle Swearingen. 2016. ERDC/CERL TR-16-29. Effects of Climate Change, Urban Development, and Threatened and Endangered Species Management on Army Training Capabilities: Firing Ranges, http://acwc.sdp.sirsi.net/client/en_US/search/asset/1054587

Army stationing analyses have historically been conducted under the assumption that conditions at and around installations will remain static. In 
reality, the natural, social, and built infrastructure changes over time, and this non-stationarity should be considered in stationing analyses to ensure continuation of each installation's mission. This work documents efforts completed in FY15 that addressed the temporal aspects of population growth and its potential for negatively impacting an installation's training areas, and the potential impact of currently listed and species at risk of being listed to the endangered species list. A modified method for estimating population impact and a new method for estimating the impact of listed and at-risk species are described.

Juliana M. Wilhoit, Grace M. Díaz-Estrada, James P. Miller, et al. 2016. ERDC/CERL TR-16-32. Water Stress Projection Modeling, http://hdl.handle.net/11681/20661

U.S. Army stationing is a constant multiscale process. Large scale stationing, which is identified with strategic realignments, requires

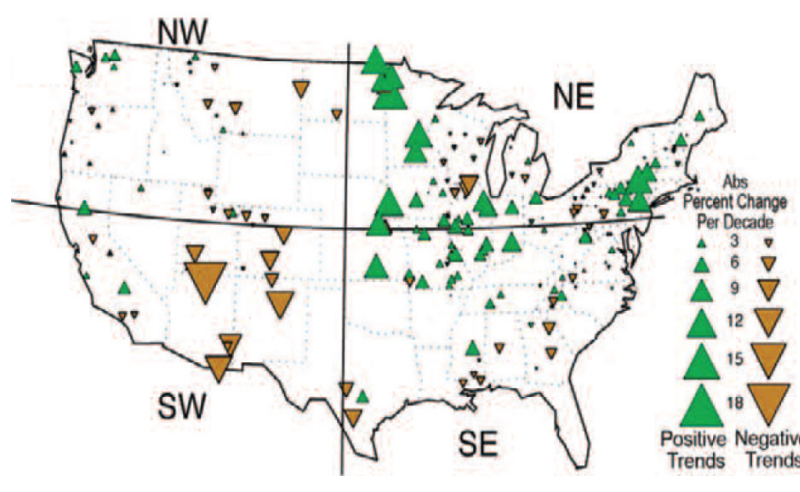
Magnitude of annual floods from the 1920s to 2008 shown with magnitude (size) and direction (color). some level of modeling to determine whether the movement of tactical equipment and large numbers of personnel is both economical and continues to meet future long-term strategic requirements. This work explored how climate change implications on water resources may affect military installations in the future, and used that information to outline WAter Stress Projection (WASP) [model] model, which serves as a decision support system tool that integrates water stressors resulting from global climate change and regional growth to assess the availability of water to an installation in the future. WASP is a tool that provides a scalable solution to incorporate water into the U.S. Army stationing process and to generate a maximum number of personnel at an installation, which can be used as an Optimal Stationing of Army Forces (OSAF) constraint. To test the impact of climate change on the U.S. Army, the model was applied to five case study installations located across the continental United States in a variety of climate zones. 
John W. Weatherly and Mattson A. Rosenbaum. ERDC/CRREL TR-17-17. Use of Heat- and Fire-Risk Indices to Project Local Climate Impacts on Selected Army Installations, http://dx.doi.org/10.21079/11681/26650

Climate change is expected to produce increasing impacts on training and infrastructure on Army installations in the coming decades. Planning to enable Army installations to adapt to the changing climate can be supported by suitable estimates of climate impacts over timeframes suitable for strategic plans. This work computed the impacts of future climate change on available training days for seven sample Army installations using projections of temperature and precipitation from global climate models. The number of days with heat-related training restrictions and fire risk from live-fire training were calculated using observed weather station data and climate model projections for several future climate scenarios. For these installations, increased temperatures in time periods centered on 2030, 2050, and 2090 result in a greater number of days with heat categories above 84 and $90{ }^{\circ} \mathrm{F}\left(28.9\right.$ and $\left.32 .{ }^{\circ} \mathrm{C}\right)$ and with high fire risk. The climate impact on heat-affected training days is greater in the U.S. Southeast, where high humidity also contributes most to the heat index. The impact on the fire risk for training is greater in the U.S. Southwest, where the low precipitation and high temperatures contribute to the high drought index. Future work will include additional installations and climate variables.

Michelle E. Swearingen, Andrew Fulton, Wade Wall, et al. 2016. ERDC TR-16-1. Effects of Climate Change and Urban Development on Army Training Capabilities: Firing Ranges and Maneuver Areas, http://hdl.handle.net/11681/20656

Army stationing analyses have historically been conducted under the assumption that most conditions at and around installations will generally remain static. Previous optimal stationing analyses have resulted in substantial costs associated with moving units, constructing buildings and roads, and local in-

Ten-mile buffer with census tracts overlaid.

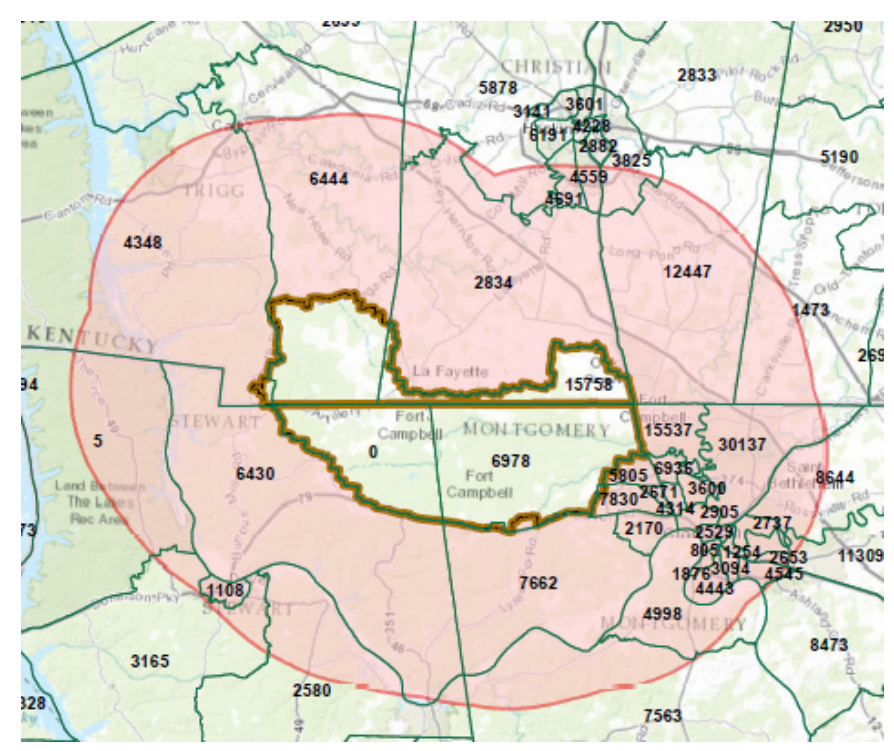


vestments in the development of off-post housing, shopping facilities, eating, and other businesses that provide quality of life for soldiers and their families. In reality, the capacity of the natural, social, and built infrastructure changes over time, and this non-stationarity should be considered in stationing analyses to: (1) avoid premature abandonment of expensive buildings and associated infrastructure, and (2) avoid costly realignments to locations where capacity is being adversely affected by change. This report documents efforts completed in FY14 that began to investigate how potential changes associated with climate and urban development might affect the ability of Army installations to continue to conduct training on firing ranges and in maneuver areas.

Juliana Wilhoit, Scott Tweddale, Matt Hohmann, et al. ERDC/CERL TR-16-29. Effects of Climate Change, Urban Development, and Threatened and Endangered Species Management on Army Training Capabilities, http://hdl.handle.net/11681/20653

Army stationing analyses have historically been conducted under the assumption that conditions at and around installations will remain static. In reality, the natural, social, and built infrastructure changes over time, and this nonstationarity should be considered in stationing analyses to ensure continuation of each installation's mission. This work documents efforts completed in FY 15 that addressed the temporal aspects of population growth and its potential for negatively impacting an installation's training areas, and the potential impact of currently listed and species at risk of being listed to the endangered species list. A modified method for estimating population impact and a new method for estimating the impact of listed and at-risk species are described.
Map of urban development in relation to distance from ranges at Fort A.P. Hill.

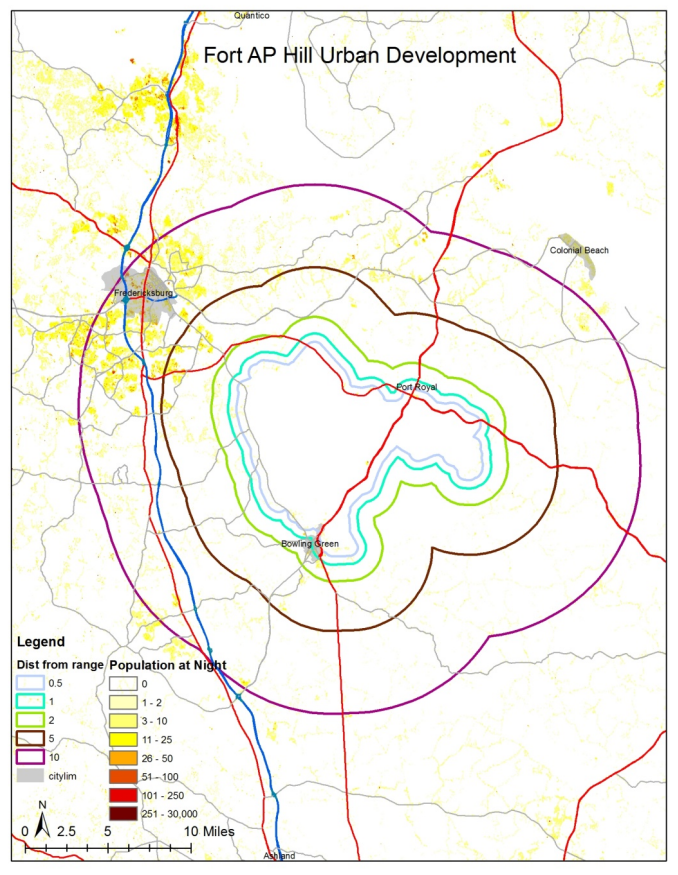


James D. Westervelt and Grace M. Díaz-estrada. ERDC/CERL SR-16-1. BlackSwan Event Assessment for Fort Leonard Wood, Missouri, http://acwc.sdp.sirsi.net/client/en_US/search/asset/1049146

Emergency preparation typically involves evaluating disaster potential and consequences, followed by disaster preparedness. Potentials are informed by history, with the easy human belief that one must obviously prepare for the past. However, a class of disasters involve events that may not have been anticipated, but in hindsight appear to be obviously overlooked. This report attempts to identify such "black-swan" events, i.e., potential disasters in the Fort Leonard Wood area that might well attract more attention in future planning exercises. 


\section{Sustainable Installations - Net-Zero Planning}

Net Zero is a strategy that strives to bring the overall consumption of resources on installations down to an effective rate of zero. The Army's vision is to appropriately manage our natural resources with a goal of achieving Net Zero Installations. Today, the Army faces significant threats to our energy and water supply requirements both at home and abroad. Addressing energy security and sustainability is operationally necessary, financially prudent, and mission essential. The Net Zero concept encompasses not only energy, but water and waste as well. The Army is investing in its installations to improve efficiencies in energy, water and waste for the benefit of the current and future force, and of the Nation.

Elisabeth Jenicek. 2016. ERDC/CERL TR-16-28. Fort Leonard Wood Net Zero Water Program: Project Documentation for Fiscal Year 2015, Distribution D.

The Army Corps of Engineers (ERDCCERL) and Fort Leonard Wood are in the fifth year of planning and execution in support of installation sustainability. Net Zero Water support for Fort Leonard Wood in this planning effort focused on developing sustainability goals and objectives and defining a set of tasks to achieve them. A 1-day water workshop for installation staff devised a prioritized list of water topics to derive specific tasks to support water sustainability and reduce water consumption and cost to the installation. The 2015
Advanced meters have the ability to measure, record, and communicate data at regular intervals.

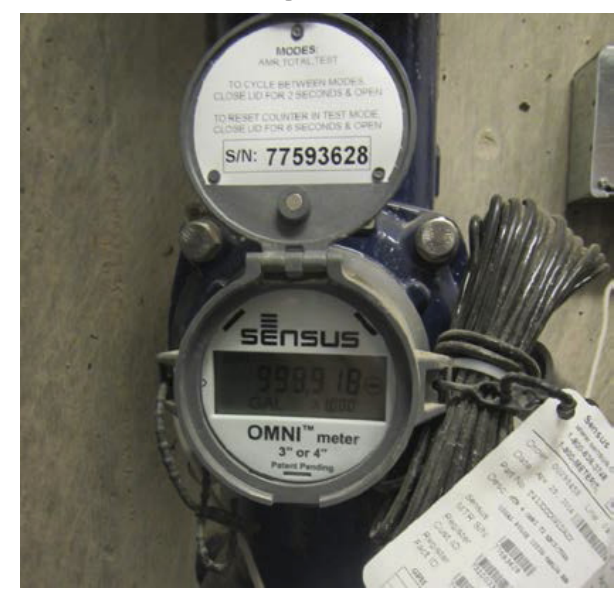
Net Zero Water effort updated the Buried No Longer analysis with local information, developed potable water leak detection recommendations, characterized high water use activities, calculated the energy cost of water, developed a strategic water-metering plan, and conducted a water analysis for 10 building types. Ongoing tasks from prior years included a water meter flow recorder analysis, stormwater planning for the Fort Leonard Wood Downtown project, water-metering recommendations, calculations of the real cost of water, and updates to the water technology retrofit guidelines. These tasks support efforts to reduce overall water use on the installation. 


\section{Sustainable Energy Solutions}

DoD has established challenging goals to increase energy efficiency and reduce greenhouse gas (GHG) emissions of their installations in all five services with an ultimate goal of Net Zero Energy (NZE) installations. From a military capability systems support perspective, power and energy are critical to sustainability. They are a consideration in many facets of military operations. The purpose of this technology focus area is to identify the sustainability needs associated with integration of power and energy into military missions.

\section{Scott Lux. 2016. ERDC/CERL TR-16-2. Demonstration of a Robust Sensor System for Remote Condition Monitoring of Heat-Distribution System Manholes: Final report on Project FO9-ARO3, http://acwc.sdp.sirsi.net/client/en_US/search/asset/1048650}

This project demonstrated a wireless remote-monitoring system for detecting and reporting steam leaks or flooding in underground heat-distribution system (HDS) manholes. The system immediately notifies maintenance personnel of critical conditions that could indicate expensive energy losses and potentially serious damage to the HDS. Demonstrated at Redstone Arsenal, $\mathrm{AL}$, the system used durable temperature and water-level sensors for operating in very high heat and humidity. Remote-monitoring nodes in-

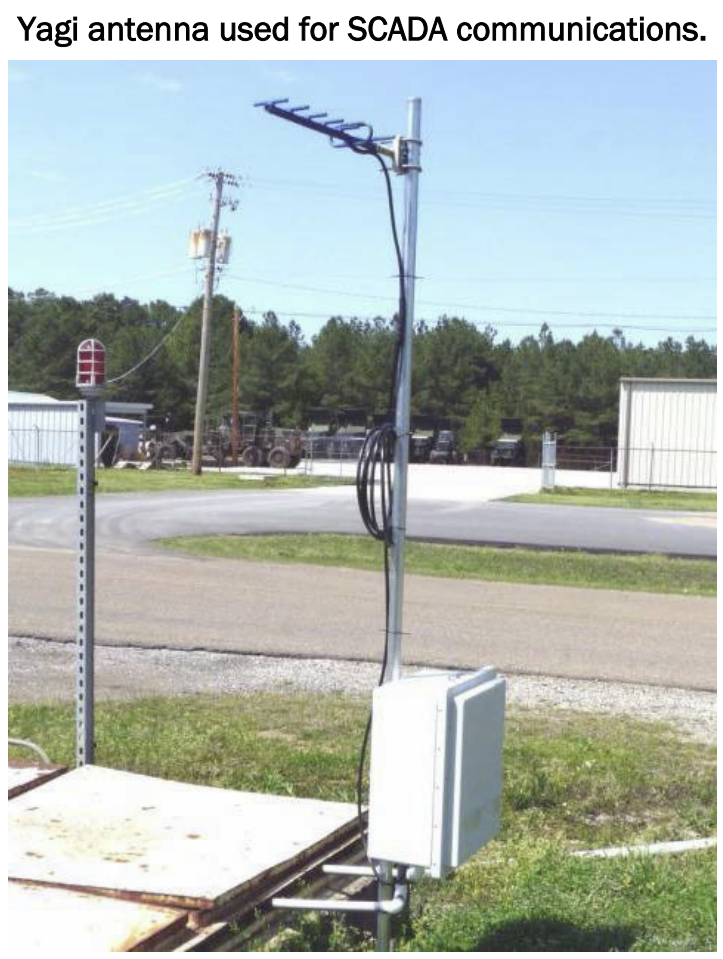
cluded remote transmitting units using one of two alternate wireless data technologies. Wireless $900 \mathrm{MHz}$ Ethernet service was installed and commissioned for eight manholes, linking them to the Redstone supervisory control and data acquisition (SCADA) system, but full integration with the SCADA system was not feasible given limitations on installation resources. Cellular data service was installed for six other manholes and commissioned successfully. Those nodes functioned for about 15 months to record 
ambient manhole conditions and email daily rollup data to the project point of contact (POC), verifying continuous operation. The functionality of the system design was validated, but important lessons were learned about electric service availability, line-of-sight antenna positioning for wireless Ethernet, and remote transmitting unit (RTU) installation. The return on investment for the cellular system was 94.6, potentially saving $\$ 534,000$ in maintenance over 30 years.

\section{Steven F. Daly. 2016. ERDC/CRREL TR-16-5. Characterization of the Lake Erie Ice Cover, http://acwc.sdp.sirsi.net/client/en_Us/search/asset/1054567}

The developing offshore wind energy industry in Northern Ohio is looking to place wind turbines in Lake Erie. The floating lake ice that forms in Lake Erie each winter is a very imBathymetry of Lake Erie.

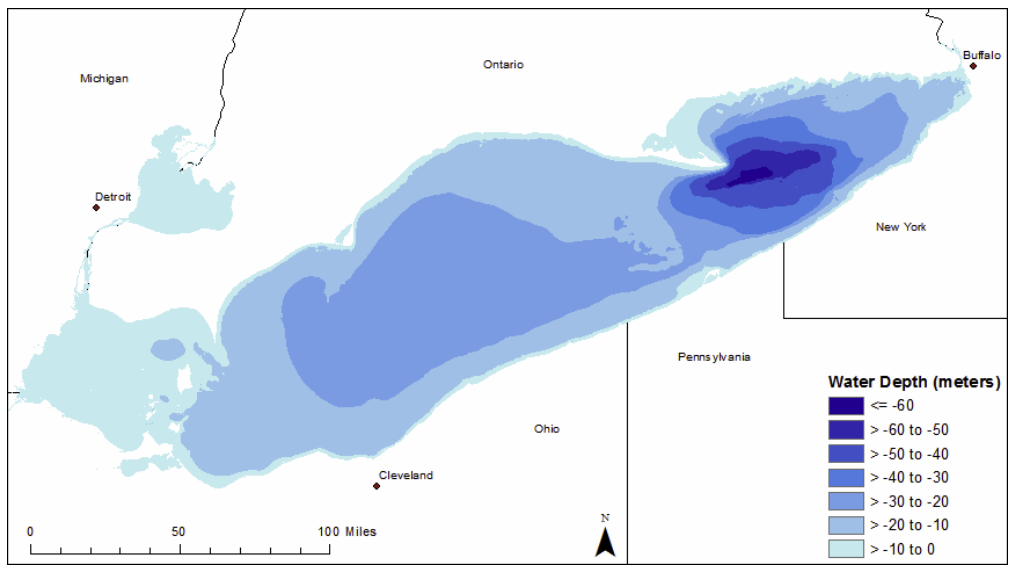

portant consideration for the design of the wind-turbine towers and for the foundations sited in the lake. This report uses historical meteorological and surface-ice-thickness observations, 41 years of ice chart information, and lake-bed surveys of ice scours to estimate the characteristics of the Lake Erie ice cover important to the design of offshore wind-turbine towers. These characteristics include the expected thickness of the ice cover due to thermal growth, the historical spatial and temporal distribution of the ice cover throughout the winter season; and the estimated consolidated layer thickness and maximum keel depths of ice ridges formed in the lake. The report also describes the results of an innovative satellite-based synthetic aperture radar survey that included multi-temporal acquisitions of the lake ice cover during the winter of 2014-15. A stationary linear feature was evident in a time series of three spatially overlapping images, suggesting a grounded ice ridge. At that time of this publication, this is the first satellite-based evidence of ice ridges in Lake Erie. 
James H. Lever. 2016. ERDC/CRREL SR-16-2. Economic Analysis of the Greenland Inland Traverse (GrIT),

http://acwc.sdp.sirsi.net/client/en_US/search/asset/1049988

The GrIT transports fuel and cargo over Ski-equipped LC-130 at Summit Station during cargo snow to resupply science stations on the Greenland ice sheet from Thule Air Base. GrIT offers an alternative to the traditional LC-130 airlift resupply from

Kangerlussuaq, Greenland. In this report, we assess the economics of GrIT relative to airlift resupply operations by comparing the costs of each mode to deliver the same fuel and cargo based on data from the 2012 and 2014 seasons. 


\section{Sustainable Water \& Waste Resources}

In recent years, military installations have been impacted by conditions of increasing demand and decreasing supply of high quality fresh water. Urban growth adjacent to installations has combined with prolonged regional droughts to place key military missions at risk due to limited availability of this vital resource. Regional competition for water threatens continued availability of adequate water both on post and in adjacent urban areas.

This focus area addresses access to, and the sustainable use of, water resources. Activities include understanding water resources status, quantities and qualities; conservation approaches and technologies; water reuse technologies and approaches; and other capabilities to improve and enhance the availability and quality of water as a sustainable resource.

Philip T. Gidley. 2017. ERDC/EL TR-17-19. Methy/mercury Screening Mode/s for Surface Water Habitat Restoration: A Case Study in Duluth-Superior Harbor, http://dx.doi.org/10.21079/11681/25606

The placement of dredged material for creating vegetated shallow water aquatic habitat is being assessed for changes in long-term bioavailability of mercury (Hg) to wildlife and humans. The three models used in this study (HERMES, WASP, and SERAFM) were applied in different ways to explore the possible strengths of each model, rather than to make direct comparisons between models. The HERMES model, which was most explicitly changed to account for aquatic plant growth, showed the greatest increases in sediment methylmercury ( $\mathrm{MeHg}$ ). The WASP model, which was most likely simulating a situation where dredged material is placed and aquatic plants do not grow, showed the least overall changes in surface water and sediment MeHg. The SERAFM model, which had the least "flushing" of the surface water in the restored scenario, showed the greatest increases in surface water $\mathrm{MeHg}$ (despite entered reductions in sediment $\mathrm{Hg}$ ). This study focused on the usefulness of each of the models separately for their ability to predict long-term MeHg changes in sediment, sediment porewater, surface water (including suspended particulates), and dissolved-in-surface water after the creation of shallow water habitat, relative to a "no-action" scenario at the site. 


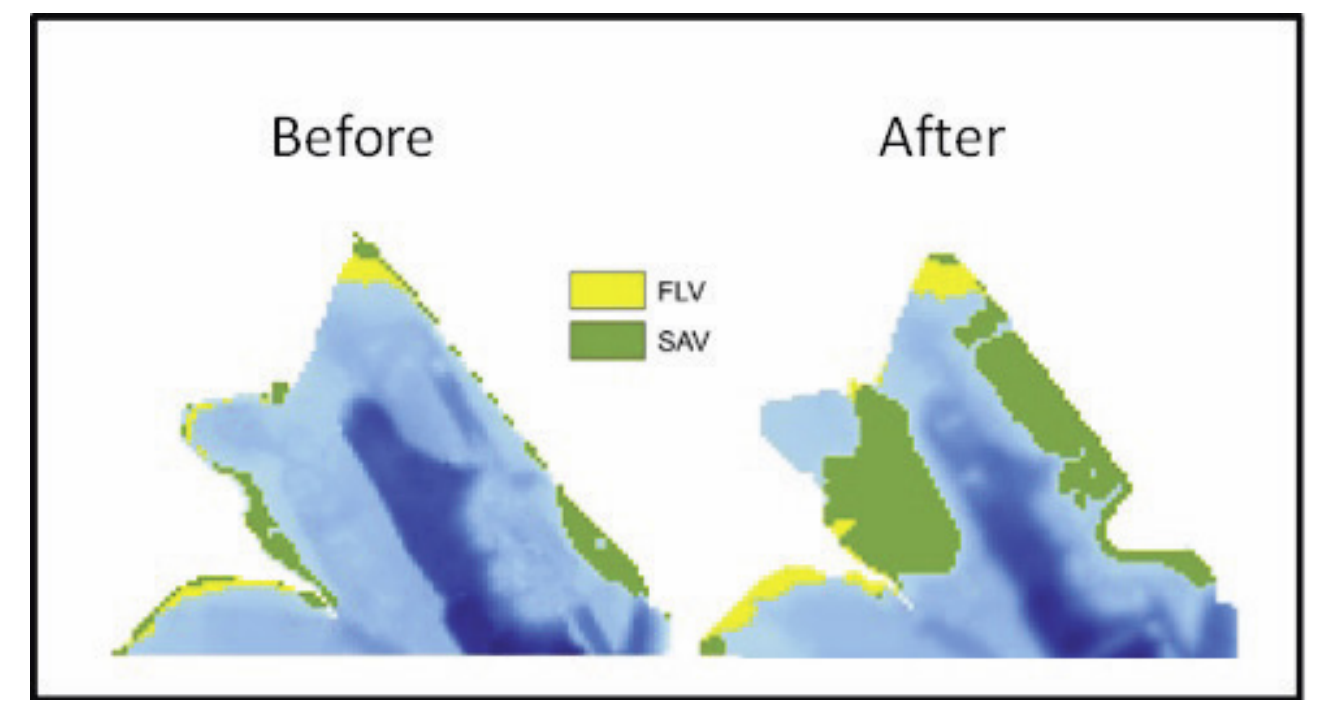

Rendition of 21st Ave before and after restoration. There will be an expected increase in submerged aquatic vegetation (SAV; green shading) and floating leaf vegetation (FLV; yellow shading) after implementation of the restoration design (images courtesy of Adam Wagner, Detroit District).

\section{Elizabeth A. Summers. 2017. ERDC/EL TR-17-01. Operational Draft Regional Guidebook for the Functional Assessment of High-Gradient Headwater Streams and Low-Gradient Perennial Streams in Appalachia, http://dx.doi.org/10.21079/11681/21462}

The (HGM) Approach is a method for developing functional indices and the protocols used to apply these indices to the assessment of ecosystem functions at a site-specific scale. This report uses the HGM Approach to develop a

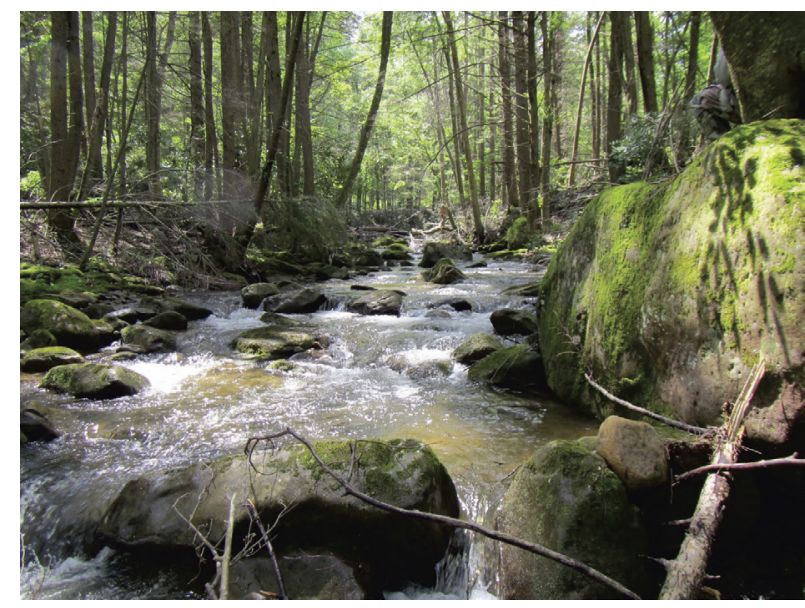

Regional Guidebook to:

(a) characterize high-gradient Representative perennial stream within (greater than four percent the reference channel slope) domain.

ephemeral and intermittent streams, known collectively as headwater streams, and wadeable, shadeable perennial streams with less than four percent slope, known as perennial streams, in the Appalachian region; (b) provide the rationale used to select functions for the headwater and perennial stream subclasses; (c) provide the rationale used to select assessment 
variables at the stream, riparian/buffer zone and watershed levels; (d) provide the rationale used to develop assessment equations; (e) provide data from reference streams and document their use in calibrating variables and assessment equations; and (f) outline the necessary protocols for applying the functional indices to the assessment of stream functions. The rapid assessments provided in this guidebook utilize structural components of streams and their watershed and can be used in conjunction with assessment of water quality and biotic communities if desired.

\section{Brook D. Herman. 2017. ERDC/EL TR-17-11. Review and Evaluation of Reservoir Management Strategies for Harmful Algal Blooms, http://dx.doi.org/10.21079/11681/22773}

The purpose of this report is to review and evaluate available information regarding reservoir operation strategies for management of harmful algal blooms (HABs). HABs can be problematic, creating eutrophication, and taste and odor issues. HABs also involve the release of toxins in the water column, which can cause sickness by ingestion and skin contact. This report presents the results of a review of journal articles, reports, published accounts of potential manage-

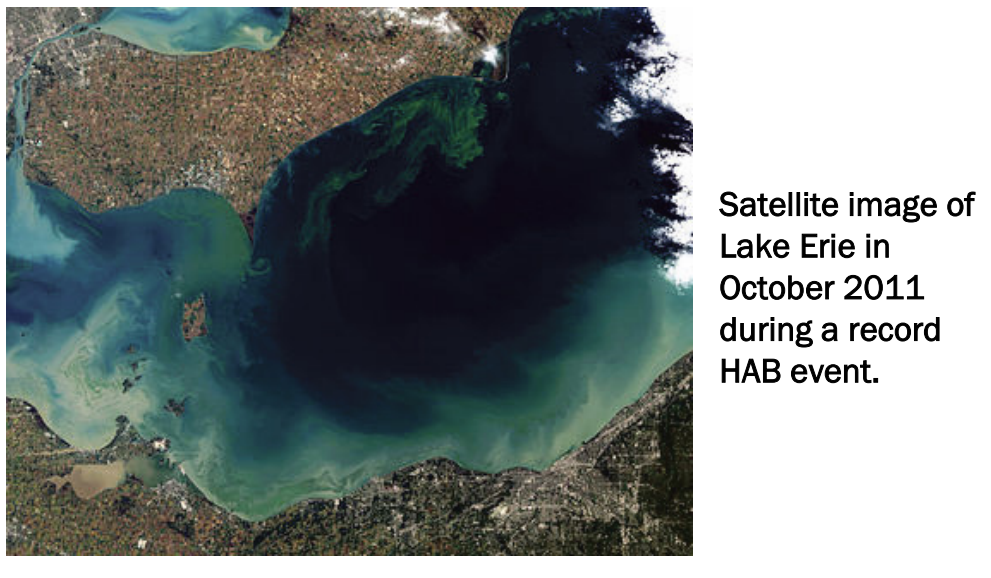
ment options, effectiveness of management, and potential impacts of management actions on lake/reservoir ecosystem processes and biota, and recommendations for future research. This report concluded there is a range of methods that can be applied to address HABs in reservoirs. The efficacy of these methods decreases in larger reservoirs. No one method individually solves all problems or is applicable in all cases, a combination of methods will likely be needed. More research is needed to effectively control and prevent HABs. 
Zhonglong Zhang. 2017. ERDC/EL TR-17-18. Hydrologic Engineering Center River Analysis System (HEC-RAS) Water Temperature Models Developed for the Missouri River Recovery Management Plan and Environmental Impact Statement, http://dx.doi.org/10.21079/11681/23707

This report describes the Hydrologic Engineering Center-River Analysis System (HEC-RAS) water temperature models developed for five Missouri river reaches (e.g., Fort Peck Dam to Garrison Dam; Garrison Dam to Oahe; Fort Randall Dam to Gavins Point Dam; Gavins Point Dam to Rulo, NE; and Rulo, NE to the mouth of the Missouri River). These models were developed based on calibrated HEC-RAS flow models that the Omaha and Kansas City Districts of the U.S. Army Corps of Engineers (USACE) provided. Of five HEC-RAS water temperature models, three models were run for an 18-year period (1995-2012) for six alternatives in support of developing the Missouri River Recovery Program (MRRP) management plan (ManPlan) and environmental impact statement (EIS). The HEC- RAS water temperature model results for each river reach and each alternative are presented in this report. Likewise, the sources of model uncertainty are discussed in this report as well.

Steven J. Currie. 2017. ERDC/EL SR-17-04. Utilizing Wetlands for Phosphorus Reduction in Great Lakes Watersheds: A Review of Available Literature Examining Soil Properties and Phosphorus Removal Efficiency, http://dx.doi.org/10.21079/11681/24838

Excess nutrient loading continues to impact water quality within the Great Lakes. The Great Lakes Restoration Initiative (GLRI) seeks to improve water quality through the reduction of phosphorus inputs from surrounding watersheds. Both natural and constructed wetland ecosystems display the capacity to reduce phosphorus inputs in a variety of agricultural and urban settings. However, maximizing the efficiency and benefits of wetlands for phosphorus reduction requires an understanding of nutrient cycles, soil-nutrient interactions, legacy phosphorus, and other factors. The current report synthesizes existing

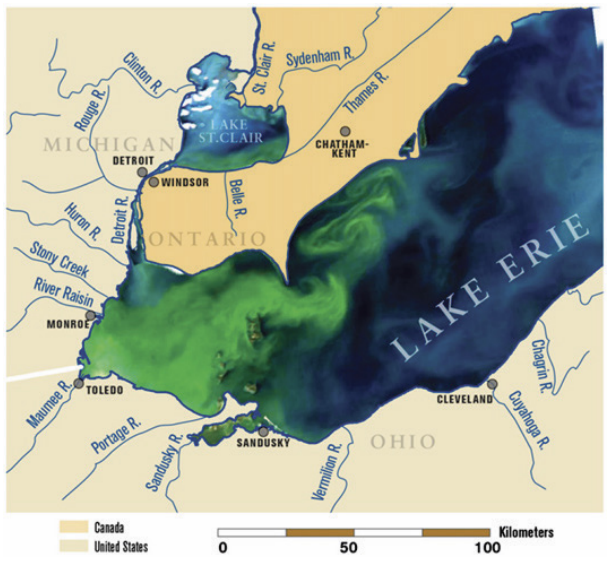

Excess $\mathrm{P}$ loading from surrounding watersheds results in poor water quality, including large algal blooms observed in Lake Erie (From Michalak et al. 2013). 
literature related to wetland phosphorus retention, depicts opportunities for improving water quality outcomes, and identifies opportunities for further research.

\section{Jacob F. Berkowitz. 2017. ERDC/EL TR-17-13. Evaluation of Wetland Hydrology in Formerly Irrigated Areas, http://dx.doi.org/10.21079/11681/22785}

The application of irrigation waters has the potential to alter soil morphology, patterns of hydrology, and the distribution of plant communities. As a result, the identification of wetlands in irrigated areas remains challenging. The following report is the first to evaluate the capacity of wetland hydrology to persist following the cessation of external water inputs for the purposes of wetland identification. Twelve of the thirteen study locations examined met the established criteria for wetland identification. The spatial extent of wetland hydrology was determined on-site and compared to

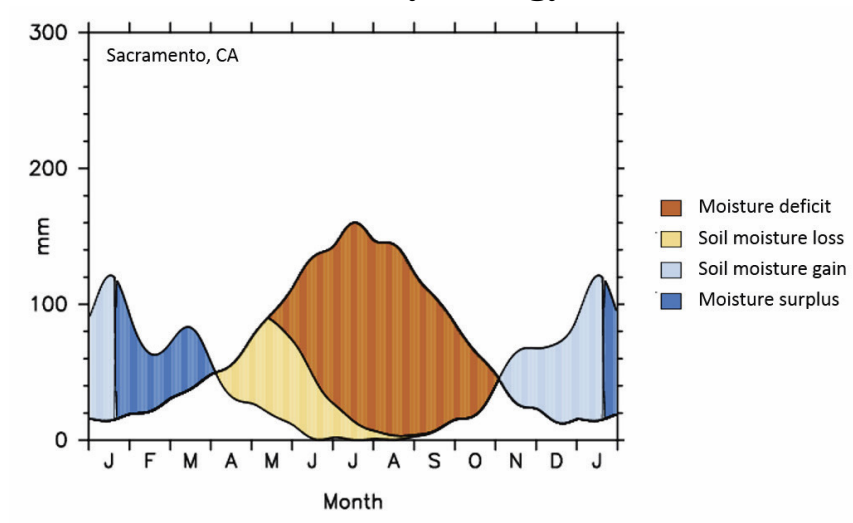

Water budget for Sacramento, CA (WebWIMP 2003). estimates based upon an analysis of aerial imagery. Findings suggest that aerial image interpretation provides a useful, but conservative approach to identifying areas of wetland hydrology in formerly irrigated areas. A framework is proposed to support wetland delin-

eations conducted in formerly irrigated areas incorporating off-site evaluations, site visits conducted during the regular wet portion of the year, and analysis of rainfall normality.

Jacob F. Berkowitz,. 2017. ERDC/EL TR-17-14. Operational Draft Regional Guidebook for the Rapid Assessment of Wetlands in the Region of Alaska, http://dx.doi.org/10.21079/11681/23955

This guidebook describes a rapid approach to assessing wetlands within the Arctic Foothills and Arctic Coastal Plain (North Slope) region of Alaska. This report utilized established approaches to (1) characterize regional wetlands, (2) provide the rationale used to determine assessment scores, (3) describe assessment variables utilized, (4) outline the developed assessment equations, and (5) provide a step-by-step protocol for applying results. 
The region's remote nature and short growing season limits the time period during which on-site data can be collected. As a result, the developed method allows for a tiered approach utilizing (1) an assessment based upon off-site data (remotely sensed or desktop resources) only or (2) an assessment using a combination of on-site (field data collection) and off-site data collection. On-site data collection may be required at the discretion of USACE. Several scenarios are presented to aid users in conducting the rapid wetland assessment.

\section{Curtis Fey. 2016. ERDC TR-16-17. Organic \\ Waste Diversion Guidance for U.S. Army Installations, http://acwc.sdp.sirsi.net/client/en_US/search/asset/1052266}

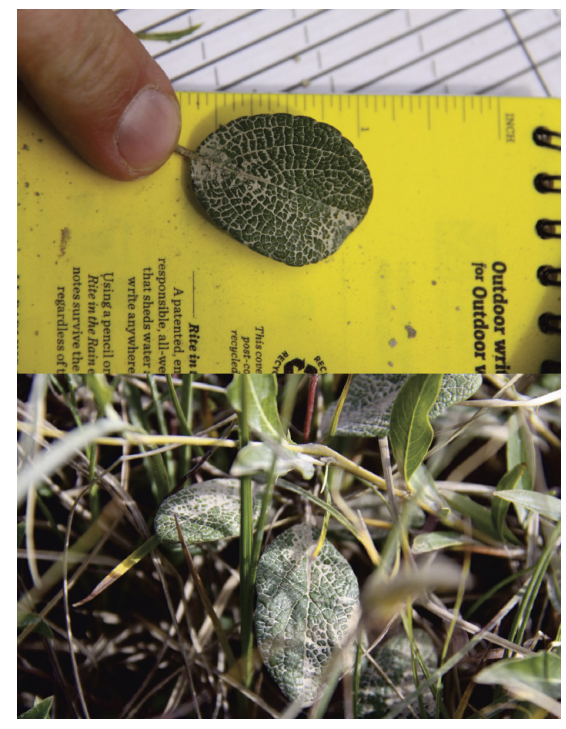

Example of dust accumulation on vegetation.

Methods of organic waste diversion currently being employed by U.S. Army installations were reviewed to provide recommendations and case studies as well as identify best practices. As part of the Army's Net Zero Installation Strategy, it is essential that installations reduce the amount of solid waste they send to landfills. Food and other organic waste, such as yard trimmings and wood residuals, are a major component of the solid waste

In-vessel food waste composting system.

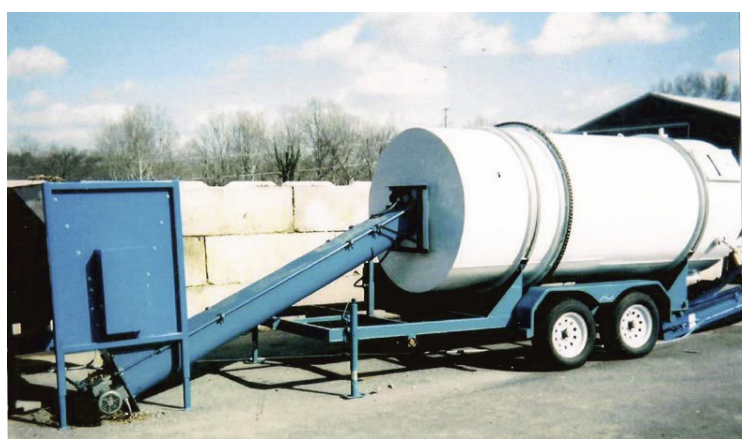
generated by installations that can be reduced, repurposed, or transformed. Both on- and off-post diversion alternatives are discussed, and case studies from U.S. military installations are provided as examples. Wherever possible, examples of documentation language (e.g., contract statements, Memorandums of Agreement [MOAs]/Memorandums of Understanding [MOUs]) are provided for contractor support of diversion activities. The report identifies mature and available small-scale organic waste management technologies, and the associated benefits, concerns, and conditions for their successful use on an installation are examined. An excel-based decision tree accompanies the report to provide guidance for 
selecting technologies or practices that suit an installation's specific capacities and preferences. The analysis provided is applicable to any Army installation or other sizable organization in the early stages of considering how to divert organic waste from a landfill.

Ryan Busby. 2016. ERDC/CERL TR-16-1. Demonstration of Combined Food and Landscape Waste Composting at Fort Leonard Wood, MO: Fort Leonard Wood Installation Strategic Sustainable Plan, http://acwc.sdp.sirsi.net/client/en_US/search/asset/1048226

While nearly 90\% of landscape wastes are recovered and processed into soil amendments and organic fertilizers using simple composting technologies, less than $3 \%$ of food wastes are recovered and recycled and the remainder are landfilled at considerable cost. Executive Order 13101 calls for DoD to incorporate waste prevention and recycling into their daily operations. Although most Army installations have effective landscape waste collection and recycling capabilities, they capture very little food waste for recycling. To initiate the incorporation of organic waste treatment technologies into daily activities at Army installations, this work investigated the logistical and economic feasibility of this technology and demonstrated food waste composting at Fort Leonard Wood, MO.

Jacob F. Berkowitz. 2016. ERDC/EL TR-16-6. Identifying Areas of Potential Wetland Hydrology in Irrigated Croplands Using Aerial Image Interpretation and Analysis of Rainfall Normality, http://acwc.sdp.sirsi.net/client/en_US/search/asset/1049990

The following report provides a framework for evaluating areas with potential wetland hydrology in irrigated and formerly irrigated croplands. The document is designed to provide insight into the complexity of identifying irrigated wetlands and to support current guidance. Additionally, the analysis conducted helps to identify and refine areas that can be targeted for future investigation, including the installation of onsite groundwater monitoring equipment. The information herein supports and supplements current approaches and

Highlighted area displays evidence of a shift in vegetation, indicating potential soil saturation.

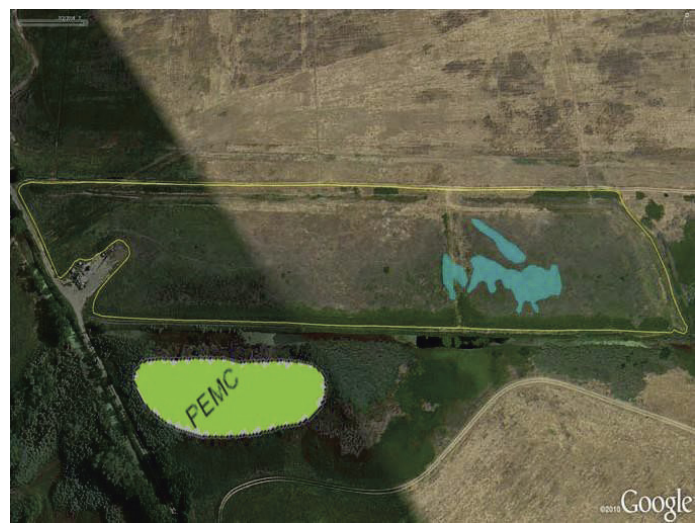


is not intended to replace or supersede current USACE national, division, or district level guidance for making wetland determinations in irrigated croplands. The procedures in this document should not be the sole basis for making wetland determinations for the purposes of the Clean Water Act; rather, these procedures are intended to supplement existing guidance and provide supporting information for making wetland determinations. 


\section{Sustainable Facilities and Infrastructure}

The purpose of this focus area is to help USACE, the Army, and DoD work toward achieving net zero and sustainable planning, design and development goals. The focus area team leaders are part of the Sustainable Design and Development Directory of Expertise (SDD DX) that the Corps established to provide support in developing criteria, research and development, design and construction support services, and training and advisory assistance. In this technology area, CASI also provides support and collaboration with the U.S. Green Building Council (USGBC) and other organizations involved in sustainable design and development (SDD).

Rebekah C. Wilson. 2017. ERDC/CERL TR-17-19. Demonstration of Antimicrobial Corrosion-Resisting Interior Coating Systems for Military Facilities in Warm, Humid Locations: Final Report on Project F10-AR04, http://dx,doi.org/10.21079/11681/22647

The placement of dredged material for creating vegetated shallow water aquatic habitat is being assessed for changes in long-term bioavailability of mercury (Hg) to wildlife and humans. The three models used in this study (HERMES, WASP, and SERAFM) were applied in different ways to explore the possible strengths of each model, rather than to make direct comparisons between models. The HERMES model, which was most explicitly changed to account for aquatic plant growth, showed the greatest increases in sediment methylmercury ( $\mathrm{MeHg}$ ). The WASP model, which was most likely simulating a situation where dredged material is placed and aquatic plants do not grow, showed the least overall changes in surface water and sediment MeHg. The SERAFM model, which had the least "flushing" of the surface water in the restored scenario, showed the greatest increases in surface water $\mathrm{MeHg}$ (despite entered reductions in sediment $\mathrm{Hg}$ ). This study focused on the usefulness of each of the models separately for their ability to predict long-term $\mathrm{MeHg}$ changes in sediment, sediment

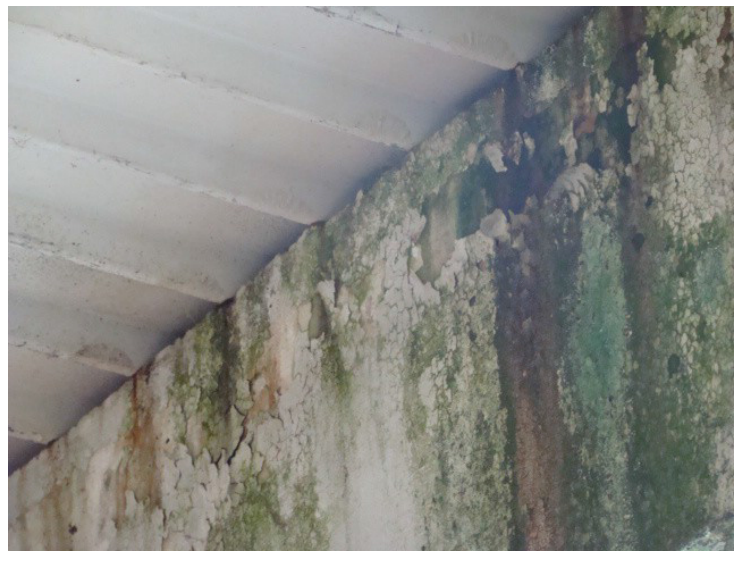

Mold in Fort Polk pumphouse with concrete block walls. 
porewater, surface water (including suspended particulates), and dissolved-in-surface water after the creation of shallow water habitat, relative to a "no-action" scenario at the site.

\section{Larry D. Stephenson. 2017. ERDC/CERL TR-17-30. Demonstration of Thermally Sprayed Metal and Polymer Coatings for Steel Structures at Fort Bragg, NC: Final Report on Project F07-AR10, http://dx.doi.org/10.21079/11681/24293}

The Department of Defense spends billions annually on corrosion-related maintenance. It has recently been estimated that at least 25 U.S. Army installations have severe corrosion problems with above-ground steel storage tanks. Coatings are widely recognized as a "first line of defense" for protecting these steel structures. Thus, the Office of the Secretary of Defense Corrosion Prevention and Control Program sponsored a project that

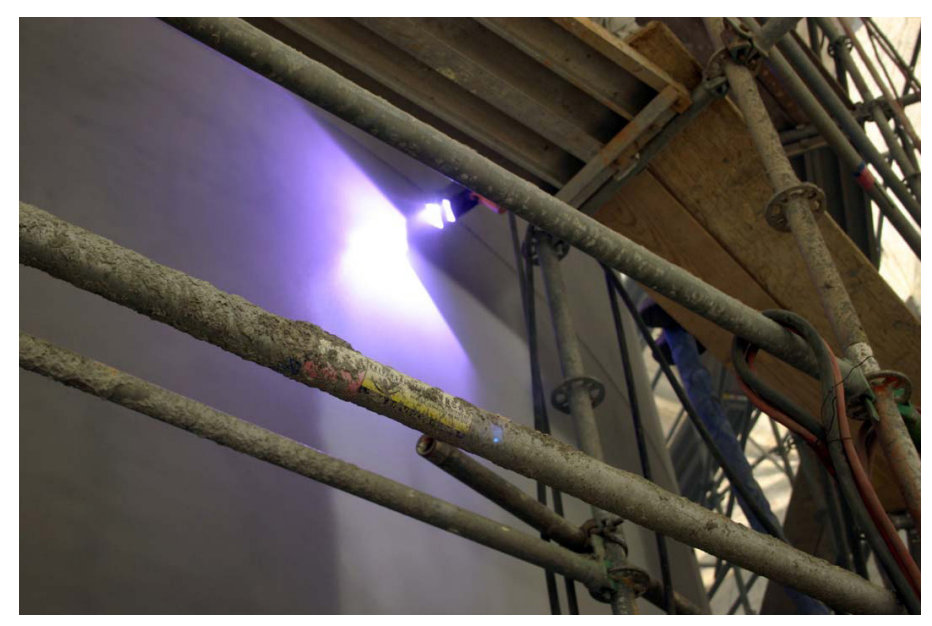

Thermal arc spray application of 85/15 alloy. demonstrated and evaluated new technology with two thermally sprayed coating systems for corrosion protection of steel structures in severely corrosive environments. The technologies included metallizing a steel tank with zinc-aluminum alloy and flame-spraying a polyolefin powder

coating on the legs of an elevated steel storage tank. This report documents the materials and application of the two coating systems and subsequent performance evaluations. Metallizing is more costly than traditional organic coatings and is often overlooked as an option. However, life-cycle costs in highly corrosive environments can actually be lower than using organic coating systems. As this project demonstrated, the flame-sprayed polyolefin coating is too costly for use on large steel structures. Guidance documents are identified to help make decisions on the use and procurement of metallizing coating systems. The project's return on investment was calculated to be 2.94 . 
Ryan R. Busby. 2017. ERDC/CERL TR-17-12. Estimating Resistance and Resilience of Military Lands Using Vegetation Indices, http://dx.doi.org/10.21079/11681/23953

Military training inevitably leads to land degradation; however, some ecosystems have higher resistance and resilience to training based on the functional traits of existing vegetation, making them preferred for longterm use. This work estimated resistance and resilience for the continental United States using dominant plant species for numerous plant communities, resistance and resilience values for plant functional groups, and national community vegetation maps. Two datasets were combined to obtain greater detail and values for all land area. Results indicate that graminoid communities have the highest resistance values, and shrublands the lowest; and that eastern deciduous forests and prairies have the highest resilience values, and evergreen forests and shrublands the lowest. This lists the resistance and resilience values of a selection of Army installations using both datasets and a new combined metric. This new method will help the Army determine the portfolio of installations that will best meet its future training land requirements.

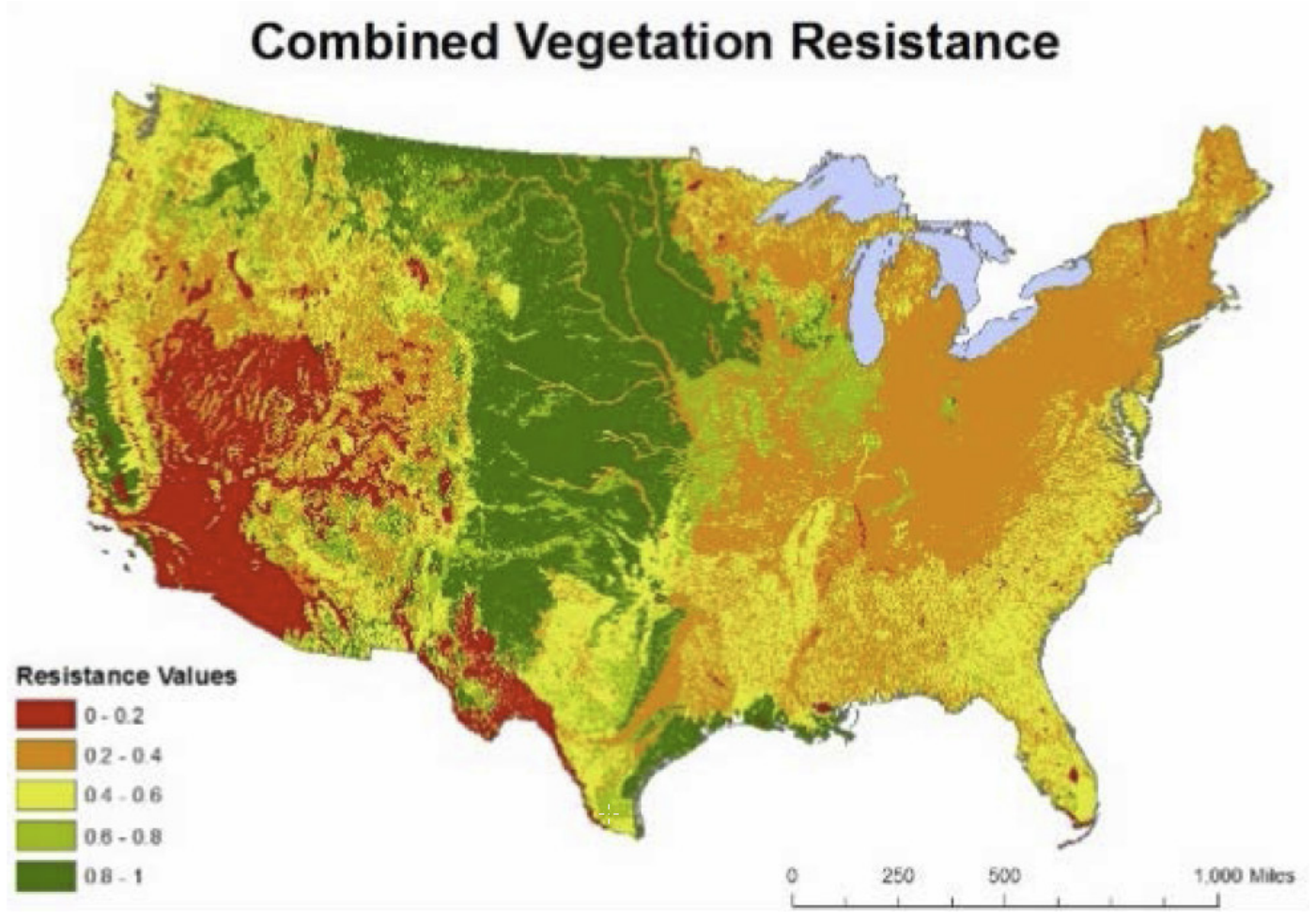

Combined Küchler and NatureServe Vegetation resistance and resilience maps. High values denote resistance to trampling and vehicular disturbance. 
Sean W. Morefield. 2017. ERDC/CERL TR-17-31. Development of a Predictive Corrosion Model Using Locality-Specific Corrosion Indices, http://dx.doi.org/10.21079/11681/24328

The U.S. Department of Defense has characterized the current approach to corrosion maintenance, which is based on simply finding and fixing damage before it becomes a concern, as inadequate to maintain mission-critical equipment and facilities to support stationing decisions. There is a need to go beyond corrosion prediction and management approaches to consider the impact of climate change on stationing decisions. To address this concern, there is a need to develop defensible, accurate approaches to project how certain installation metrics involving materials degradation are likely to change in the near future. The first step in creating a tool to meet this need is to determine how selected quantitative data, or chosen installation "metrics," will change over some specified period. This work developed and tested a corrosivity model capable of predicting corrosivity at specific sites.

\section{Stephen D. Cosper. 2017. ERDC/CERL TR-17-07. Feasibility Study of Food Waste Co-Digestion at U.S. Army Installations, http://dx.doi.org/10.21079/11681/21634}

Army Net Zero is a comprehensive approach to preserve natural resources by focusing on energy, water, and waste at Army installations. Army Directive 2014-02, "Net Zero Installations Policy" set policy and assigned responsibility to strive toward Net Zero at all Army installations, wherever fiscally responsible. As part of its greater vision of strategic sustainability, Fort Huachuca, Arizona, seeks to meet Army Net Zero objectives. The Wastewater Treatment Plant (WWTP) at Fort Huachuca is the focus of the net zero waste project discussed here. The U.S. Army Engineer Research and Development Center-Construction Engineering Research Laboratory (ERDC-CERL), with collaboration from the U.S. Environmental Protection Agency, designed a study to evaluate the feasibility of food waste co-digestion at Fort Huachuca. The study was designed to (1) reduce the amount of organic material going to landfill, (2) reduce greenhouse gas emissions, and (3) produce renewable energy. From this work, team members concluded that co-digestion of food and biosolids would be a win-win scenario for Fort Huachuca because it would help eliminate the largest part of the waste stream (food), reduce biosolids disposal costs, and generate power for operating the installation's WWTP. 


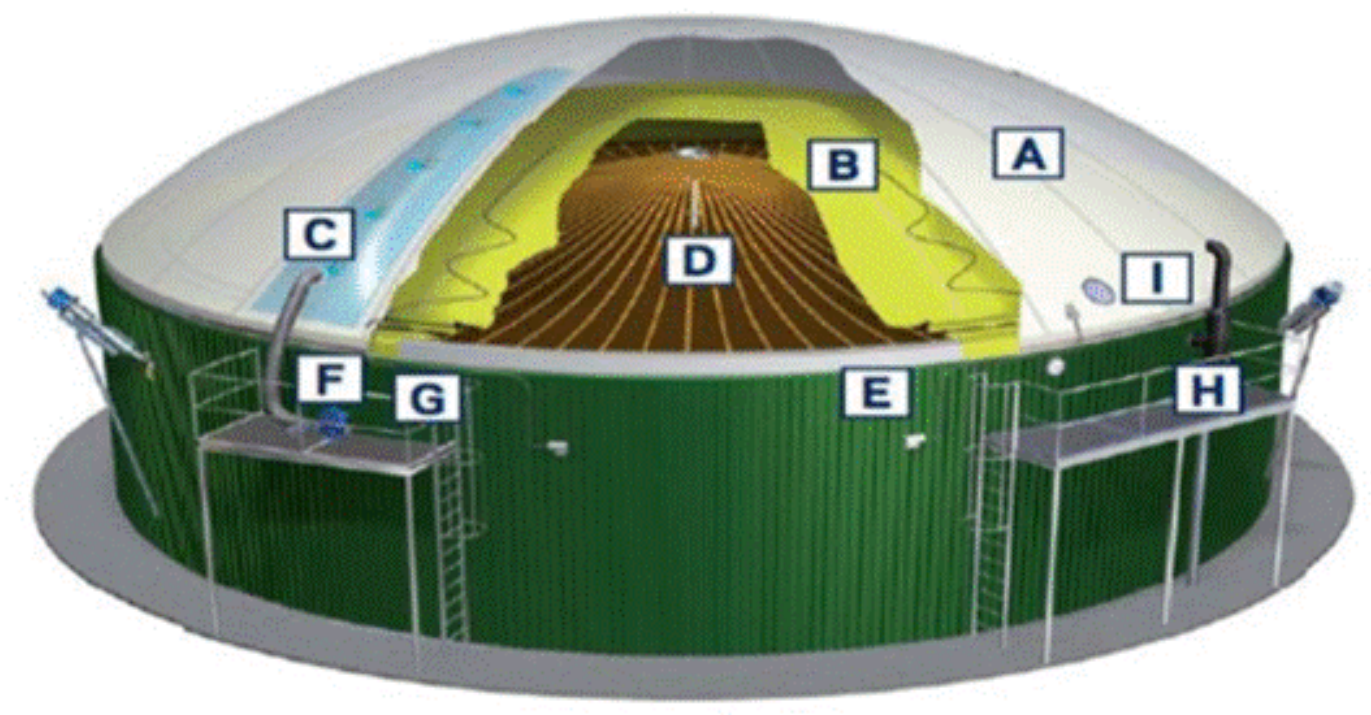

A Outer membrane B inner membrane C Air Flow System D Brace system E Anchor ring

F Air maintenance valve $\mathbf{G}$ Support air blower $\mathbf{H}$ Safety valve $\mathbf{I}$ Inspection window

Source: NaturalSystems Utilities, 2014

Dual-membrane digester, showing layering of membrane covers.

Kathleen Jones. 2016. ERDC/CRREL MP-16-1. Effect of Arctic Amplification on Design Snow Loads in Alaska: SERDP RC-2435, http://acwc.sdp.sirsi.net/client/en_US/search/asset/1051466

DoD seeks an improved understanding and capacity to respond to potential climate change impacts on built infrastructure in Alaska. Other studies have hypothesized that Arctic amplification, the rapid warming of the Arctic compared to the northern hemisphere, causes more persistent weather patterns at mid-latitudes, which increase the probaSnow Telemetry site at Little Chena Ridge, Fairbanks bility of extreme weather due to drought, flooding, cold spells, and heat waves. Annual maximum snow loads, resulting from the accumulation of snow throughout the winter season, may be strongly influenced by persistent weather patterns. We investigated County, AK.

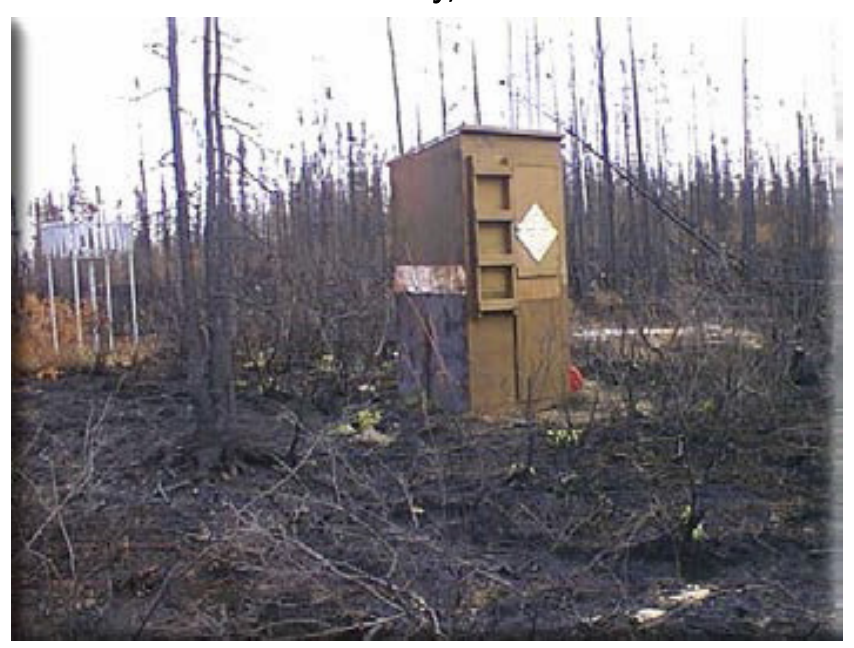


the effects of these persistent weather patterns on annual maximum snow loads and the resulting design snow loads for buildings.

\section{Lynette A. Barna. 2016. ERDC/CRREL TR-16-7. Assessment of Asphalt Concrete Reinforcement Grid in Flexible Pavements, http://acwc.sdp.sirsi.net/client/en_US/search/asset/1049726}

This report investigated the application of accepted methods of pavement structural evaluation to independently assess the potential structural benefit of asphalt geogrid reinforcement of an operational flexible highway pavement. The asphalt interlayer consisted of an elastomeric polymer coated fiberglass grid with an open configuration. The reinforcing grid was installed in the asphalt layer during construction of a maintenance overlay and has been subjected to trafficking for several years. Our structural evaluation included a geotechnical investigation and non-destructive testing using a falling weight deflectometer. Field testing was conducted when both air temperatures were above $50^{\circ} \mathrm{F}$ and no recent precipitation events had occurred. Standard testing methods were applied during the field data collection and back-calculation procedure. The back-calculation results showed no clear quantifiable benefit from including the reinforcing grid in the as-

Sample asphalt core used to determine the thickness and depth of the reinforcement grid in the test sections.

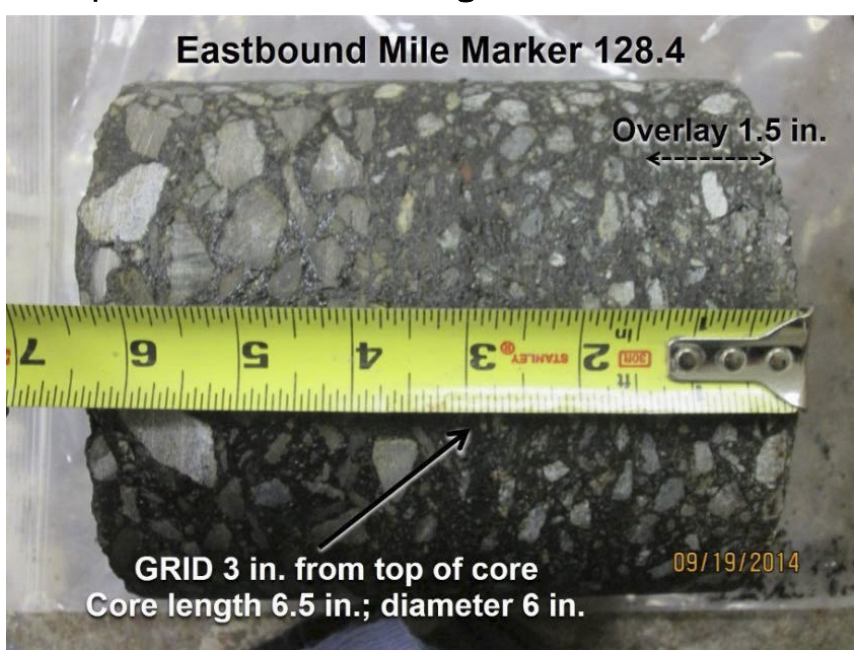

phalt layer, but this study developed a methodology to test and evaluate in situ flexible pavements with asphalt grid reinforcement. We recommend that a future structural evaluation be completed to monitor any changes in the pavement's performance. 
Terry D. Melendy. 2016. ERDC/CRREL TR-16-9. Summit Station Skiway Cost Analysis, http://acwc.sdp.sirsi.net/client/en_US/search/asset/1050687

Summit Station, Greenland, is home to a $5120.6 \times 61.0 \mathrm{~m}(16,800 \times 200$ $\mathrm{ft}$ ) skiway that acts as the lifeline for research conducted for the National Science Foundation. The LC-130 aircraft is the primary airframe depended on, each season delivering over 400,000 lb of cargo, personnel, and fuel to this remote location. A majority of the research activities takes place from mid-April to August while the station is open for the summer season. Over the past three seasons, the skiway's ability to handle this frequency of flights has increased with the implementation of new equipment and techniques, resulting in fewer jet-assisted takeoffs and longer periods of maximum allowable cargo loads. To explore further skiway improvement and cost saving techniques, this report reviews alternative maintenance and construction options based on other skiways located in Greenland and alternative available aircraft that currently operate in this region. Additionally, we were provided the entire season's total labor associated with the skiway operation and data for the cost associated with the skiway, which allowed us to quantify the current and available options. This is the first time that these metrics have been recorded and analyzed.

Each season, the skiway is constructed and maintained by a Pisten Bully $300 \mathrm{~W}$

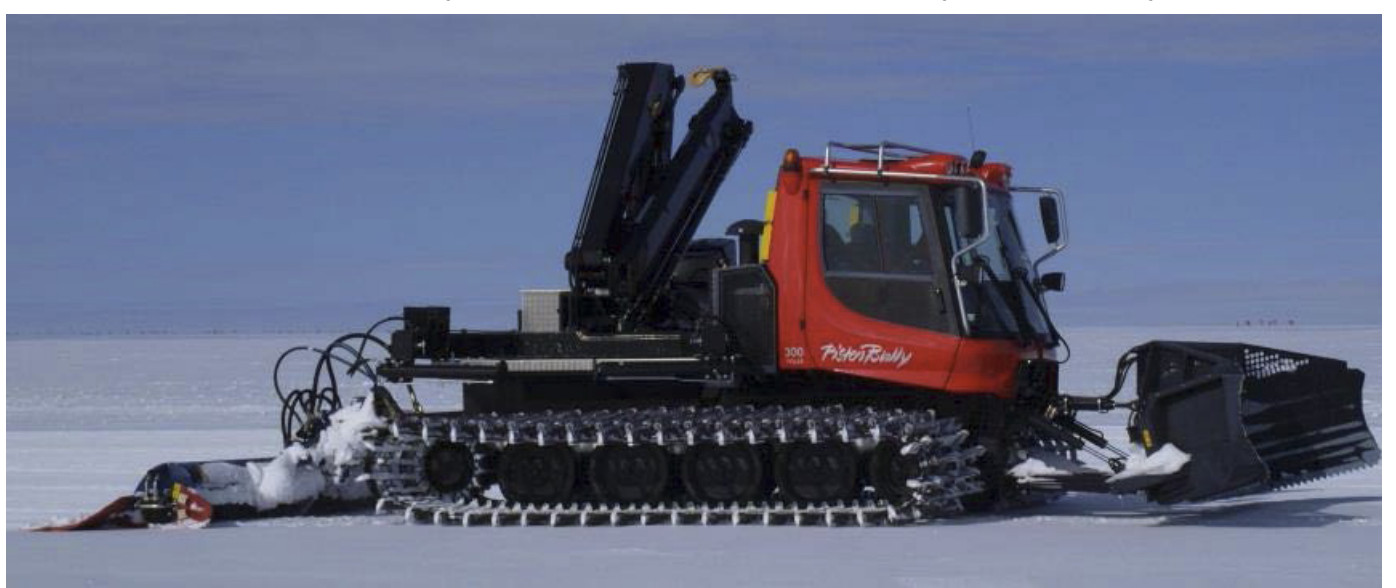


Steven A. Arcone. 2016. ERDC/CRREL TR-16-14. Ground-Penetrating-Radar Profiles of Interior Alaska Highways: Interpretation of Stratified Fill, Frost Depths, Water Table, and Thaw Settlement over Ice-Rich Permafrost, http://acwc.sdp.sirsi.net/client/en_US/search/asset/1050926

In early spring 2014, we recorded ground-penetrating-radar (GPR) profiles along several highways in interior Alaska to determine present and potential damaging thaw settlement, which could help site and design infrastructure in permafrost terrains. We used GPR pulses centered near 100,150, and $320 \mathrm{MHz}$. Comparative profiles of electrical resistivity, historical GPR profiles, and limited borehole information aided interpretations.

Beneath the Elliott Highway, Goldstream Road, and the Old Steese Highway, construction fill was recognized by its stratification; and frost depth and water table horizons were recognized by phase attributes of the reflected pulse, as dictated by dielectric permittivity contrasts, relative depths, and continuity. Undulating fill stratification indicated thaw settlement, caused by melting of buried ice. We interpreted various stratigraphic folds to represent cases of active, recent, remediated and historical settlement. A section along the Tok Cutoff Road revealed the top and bottom of massive ice within glacial moraine. Signal penetration was greatly reduced beneath the water table, and the permafrost table was not detected. This information is valuable for highway maintenance and new construction planning, especially in remote locations where information on permafrost and ice features are limited.
HF shows concentric harmonic folds; AHF shows anharmonic folds, which indicate long progressing settlement.

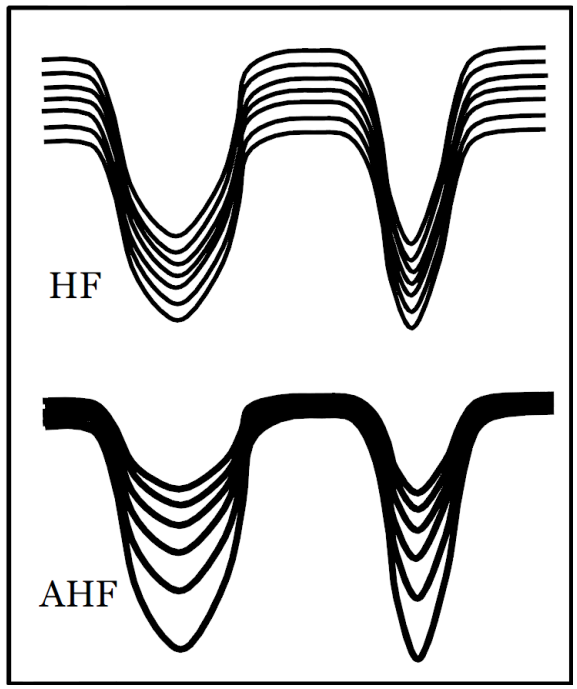


Adam Smith. 2016. ERDC/CERL CR-16-1. Matthew Jones House: Recommendations for Treatment, http://acwc.sdp.sirsi.net/client/en_US/search/asset/1049989

The Matthew Jones House (MJH) is located on Joint Base Langley-Eustis (Eustis) (JBLE-E), VA. The house is a Virginia Historic Landmark (121ooo6) and also listed on the National Register of Historic Places (\#69000342). All buildings, especially historic ones, require regular, planned, and appropriate maintenance and repair. After identifying a variety of issues with the house for JBLE-E, architectural historians at the U.S.

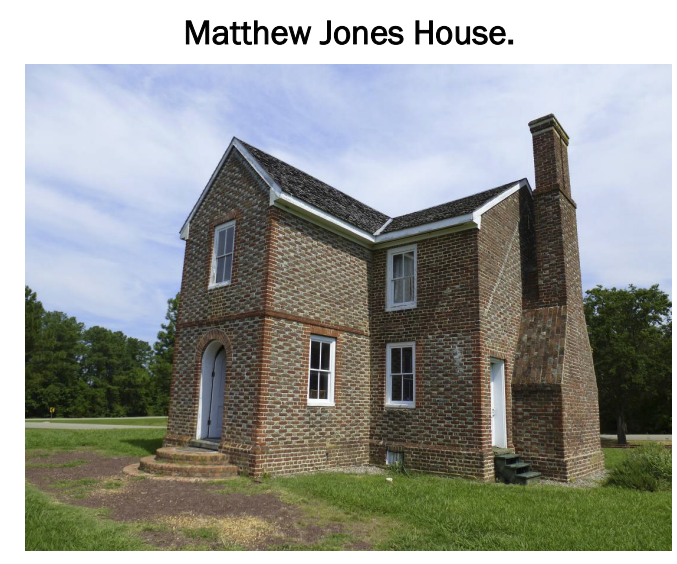
Army Engineer Research and Development Center-Construction Engineering Research Laboratory (ERDC-CERL) requested technical assistance from the National Center for Preservation Technology and Training (NCPTT) with analyzing existing materials, providing specifications for appropriate treatment materials, and making priority-level recommendations for MJH treatment by taking into account conditions and budget. The work's scope included the roofing, masonry, and Heating, Ventilating, and Air-Conditioning (HVAC) systems of the structure. This report summarizes the research and findings by the NCPTT. It also includes an engineer's report and other supplemental information. This work will continue to assist JBLE-E in maintaining this historic building.

\section{Glenn M. Suir. 2016. ERDC TR-16-15. Landscape Evolution of the Oil Spill Mitigation Sand Berm in the Chandeleur Islands, Louisiana, http://acwc.sdp.sirsi.net/client/en_US/search/asset/1051349}

The failure of the Macondo-252 well and explosion of the Deepwater Horizon oil rig resulted in the release of approximately 185 million gallons of crude oil into the Gulf of Mexico. As part of the emergency response plan, the Louisiana Office of Coastal Protection and Restoration proposed (and later constructed) sand barriers to reduce the amount of oil from reaching the Chandeleur Islands and inland wetlands, thereby protecting these sensitive ecosystem resources. This study provided general measures of the sand berms resilience, performance, and potential impacts to the Chandeleur Islands. Geographic Information System (GIS) and remote-sensing techniques were used to quantify changes in sand berm areal extent over 
time; provide shoreline, habitat, and landscape assessments of the Chandeleur Islands; and assess elevation changes and potential reworking of berm sediment into the island system. The sand berm provided short-term benefits and short-term advancement of the island's shoreline position, but the majority of those benefits were ephemeral since the berm experienced rapid degradation. The speed and degree of degradation were primarily the results of Tropical Storm Lee and Hurricane Isaac and of the construction of the berm in high-energy open water environments. Ultimately, the berm was unsuccessful in providing a barrier to retard oil from reaching the island or oil migrating into Chandeleur Sound and beyond.

Richard G. Lampo. 2016. ERDC/CERL CR-16-3. Field Testing and Summary Report for Road 5 (Morris Road) over Road 3 (Toftoy Throughway) at Redstone Arsenal, AL: Contractor's Supplemental Report for Project FO9AR16, http://acwc.sdp.sirsi.net/client/en_US/search/asset/1051686

Cyclic loading and weathering of reinforced concrete bridge decks causes corrosion of reinforcement steel, which leads to cracking, potholes, and other problems. Under the DoD Corrosion Prevention and Control Program, a deteriorated concrete bridge at Redstone Arsenal, AL, was selected to demonstrate and validate a glass-fiber reinforced polymer (GFRP) composite deck system that uses no reinforcement steel. Project results were published as ERDC/CERL TR-16-6 (August 2016). On completion of the new GFRP composite deck system, Bridge Diagnostics, Inc. was contracted to perform load testing to confirm that the bridge meets the structure's original 36-ton (HS-20) load rating and performance criteria for deflection and strain. This report documents the load test methods used by Bridge Diagnostics, Inc. (BDI) and the results. The test results indicate that the demonstrated GFRP composite deck system met the strength design specifications and passed the deflection criteria.

Typical strain gauge and linear varying differential transformer at midspan of fiber-reinforced polymer deck panel.

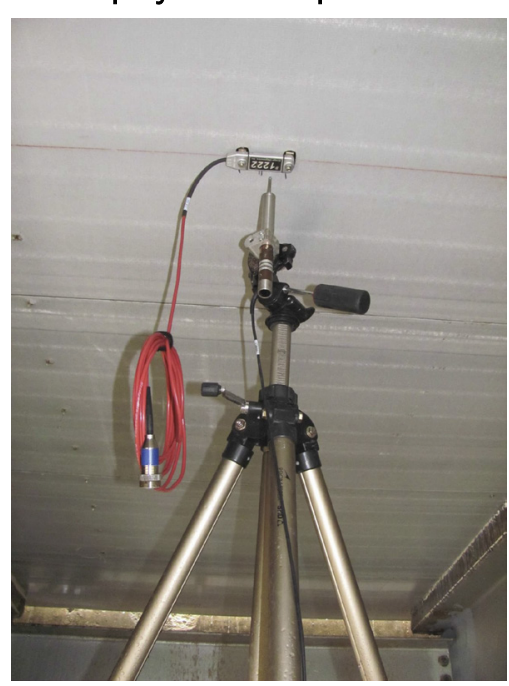


Steven Sweeney. 2016. ERDC/CERL CR-16-4. Field Testing and Load Rating Report for Bridge No. 4, Composite Grid Reinforcement of Concrete Deck, at Fort Knox, Kentucky: Contractor's Supplemental Report for Project F12-AR01, http://acwc.sdp.sirsi.net/client/en_US/search/asset/1051826

The Army has 1,500 vehicular bridges on its installations, with many experiencing high maintenance or replacement costs due to corrosion of the steel structure or of the reinforcing bar in the concrete deck. Under the DoD Corrosion Prevention and Control Program (Project F12-AR01), a span of Bridge No. 4 at Fort Knox, KY, was selected to demonstrate and validate a fiber-reinforced polymer (FRP) composite grid deck system, which does not use any reinTank crossing Bridge No. 4, Fort Knox, KY. forcement steel. The results of that project were published as ERDC/CERL TR-16-21 (September 2016). BDI, of Boulder, CO, was subcontracted to perform load testing and rating for the newly completed composite bridge deck system to confirm that the bridge span met its required load rating and performance criteria for deflection and strain. Structural testing of the bridge was performed at the end of construction and after 12 months of exposure. Results showed the bridge met all design specifications and load ratings.

Richard G. Lampo. 2016. ERDC/CERL CR-16-5. Field Testing and Load Rating Report for Bridge No. 4, Hybrid Composite Beam Span, at Fort Knox, Kentucky: Contractor's Supplemental Report for Project F12-AR15, http://acwc.sdp.sirsinet/client/en_US/search/asset/1051767

The Army has 1,500 vehicular bridges on its installations, with many experiencing high maintenance or replacement costs due to corrosion of the steel structure or of the reinforcing bar in the concrete deck. Under the DoD Corrosion Prevention and Control Program (Project F12-AR15), a span of Bridge No. 4 at Fort Knox, KY, was selected to demonstrate and validate a new corrosion-resistant hybrid composite bridge beam. 
Project results were published as ERDC/CERL TR-16-22 (September 2016). Bridge Diagnostics, Inc., Boulder, CO, was subcontracted to perform load testing and rating for the new bridge beam project to confirm that the replacement bridge span met its required load rating (HL-93) and performance criteria for deflection and strain. Results showed that the bridge met all design specifications and load ratings.

Susan Enscore, 2016. ERDC/CERL MP-16-1. Historic American Engineering Record (HAER) Level II Documentation of Launch Complexes 1/2, 3/4, 9/10, 14, and 34 at Cape Canaveral Air Force Station, Florida, http://acwc.sdp.sirsi.net/client/en_US/search/asset/1050427

This report presents HAER Level II documentation of Launch Complexes 1/2, 3/4, 9/10, 14, and 34, Cape Canaveral Air Force Station (CCAFS), FL. These facilities played an important role in the American missile and manned space programs that began largely as a result of the Cold War. As the arms race expanded in the 1950 s and 1960 s, missile systems with increasing range and destructive power were deployed on American and foreign soil. Bringing these systems to operational readiness required long, complicated testing programs and specialized facilities to support them. A national effort to put men on the moon also required specialized facilities at Cape Canaveral. These five complexes were constructed in the 1950 s and early 1960s. Launch Complexes $1 / 2,3 / 4$, and $9 / 10$ were used exclusively for rocket and missile testing, and Launch Complexes 14 and 34 also used for manned spaceflight. Launch Complexes 14 and 34 are part of the CCAFS National Historic Landmark District established in 1984.

Launching of Snark missile from Pad 2, March 3, 1960.

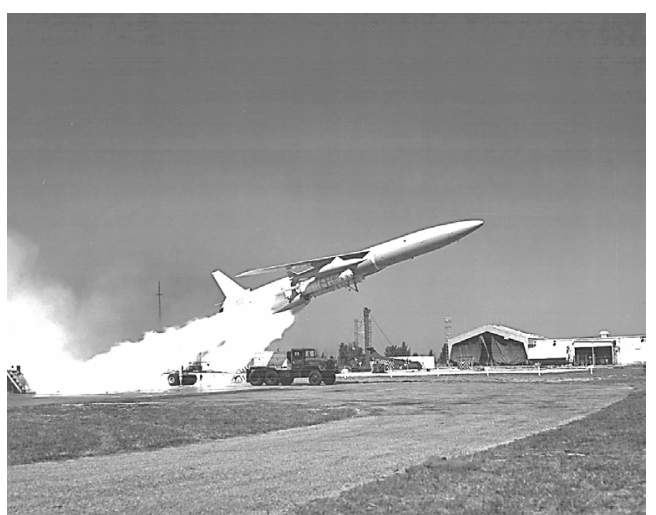


Sunny Adams. 2016. ERDC/CERL TR-16-4. Cultural Landscape Analysis of Existing Historic Districts: Picatinny Arsenal, New Jersey,

http://acwc.sdp.sirsi.net/client/en_US/search/asset/1050146

This study documents the cultural landscape at Picatinny Arsenal, focusing on five existing historic districts. This work looks at the historic development and discusses the existing conditions within each of the five districts. It analyzes the features within each district for their historic significance and integrity, and based on this analysis, makes treatment recom-

Bldg.117, former stables.

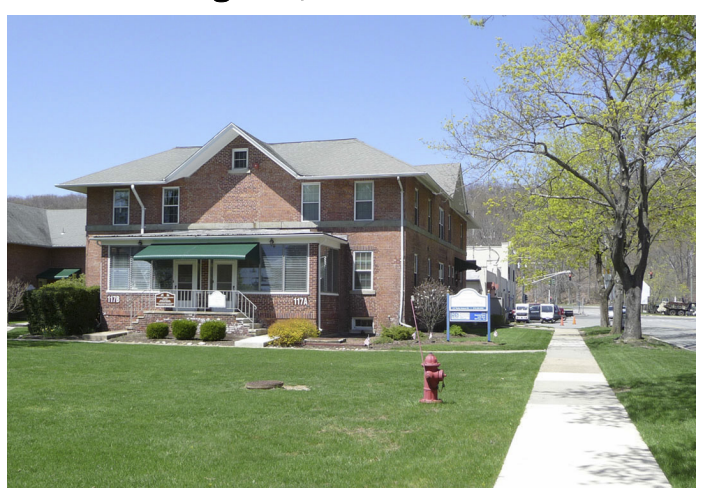

mendations. This document

meets the requirements for Federal agencies to address their cultural resources which are defined as any prehistoric or historic district, site, building, structure, or object. Especially relevant is Section 110 of the National Historic Preservation Act, which requires Federal agencies to inventory and evaluate their cultural resources.

Clint A. Wilson. 2016. ERDC/CERL TR-16-5. Demonstration of a Liquid-Applied Liner System for Corrosion Protection and Rehabilitation of Wastewater System Structures: Final Report on Project F11-AR24, http://acwc.sdp.sirsi.net/client/en_US/search/asset/1049266

Concrete and masonry structures in DoD wastewater collection and treatment systems severely corrode over time. Causes include biologically generated sulfuric acid, and are often related to microbially induced concrete corrosion (MICC). This report describes the demonstration of an emerging technology that uses a silicone-modified polyurea compound and closedcell foam to line deteriorating structures, creating a barrier that is highly resistant to corrosive effluents. At the demonstration site, Fort Bragg, NC, the patented "stress-skin liner" system was applied to one wastewater lift station and 11 manholes. The technology was applied by licensed contractors without problem, and visual inspection by a third-party

Finished (coated) manhole.

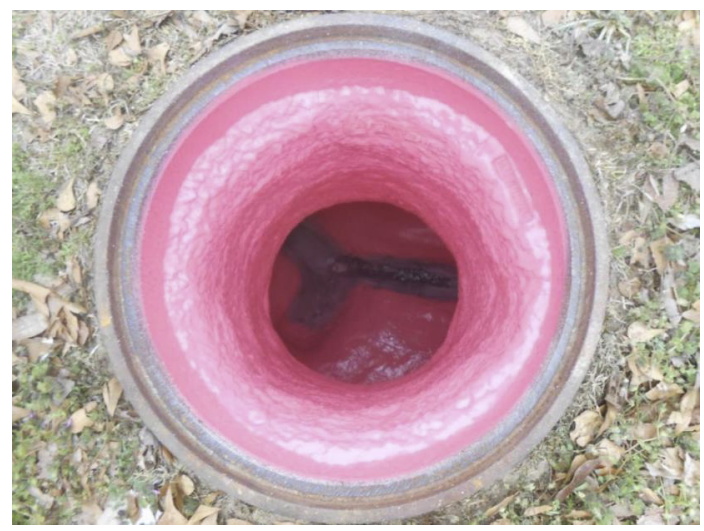


contractor confirmed that the quality and condition of the coatings was good. Because no destructive coating-adhesion testing was permitted inside the structures, concrete and masonry coupons were coated with polyurea and tested twice: once at time zero and once after 12 months. Initial coating adhesion was good, but adhesion after exposure was significantly reduced where coating edges were near to uncoated substrate that was continually wetted by sewage. Coating quality after 12 months was confirmed by visual inspection. The project return on investment (ROI) is 1.00; an alternate ROI calculated without research first costs is 5.5 .

Sunny E. Adams. 2016. ERDC/CERL TR-16-8. Character-Defining Features of Contributing Buildings and Structures in the Signal School Campus Historic District at Fort Gordon, Georgia, http://hdl.handle.net/11681/19824

This document is an architectural survey of character-defining features for the contributing features of the Signal School Campus Historic District located at Fort Gordon, GA. This survey satisfies Section 110 of the National Historic Preservation Act of 1966 as amended, and it was used to determine which elements of the buildings and structures of the historic district are character-defining features for the elements that are eligible for the National Register of Historic Places.

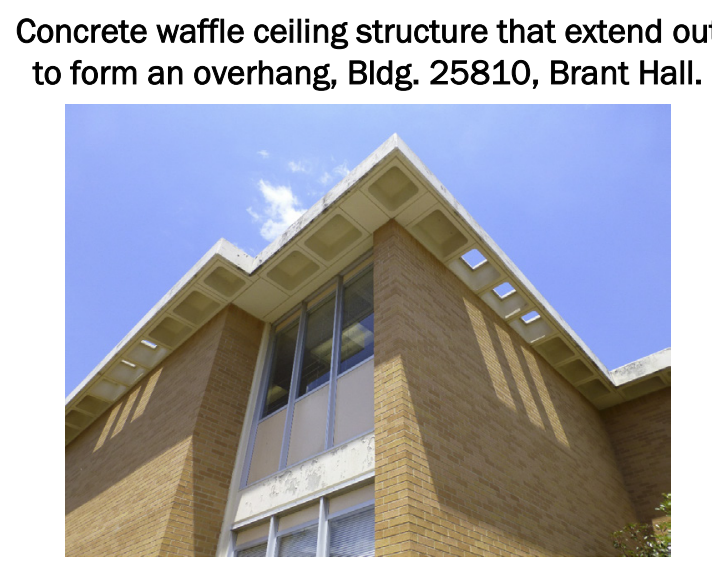

Michael Mclnerney. 2016. ERDC/CERL TR-16-10. Corrosion Control of Central Vehicle Wash Facility Pump Components Using Alternative Alloy Coatings: Final Report on Project F09-AR14, http://acwc.sdp.sirsinet/client/en_US/search/asset/1050670

Central Vehicle Wash Facilities (CVWFs) at military installations are essential for supporting the readiness of tactical vehicles. Steel washrack pumps are vulnerable to accelerated degradation where supply water is corrosive and infused with fines. Pump failure can occur with little warning, taking the CVWF out of service for unscheduled maintenance. This project tested two advanced coating materials on critical internal pump components to evaluate cost and performance. 
At the Fort Polk, LA, CVWF, inMilitary vehicle being cleaned at CVWF. ternal components of one new pump were coated with a thermally sprayed cobalt alloy, and matching components in another pump were coated chemically with an electroless nickel (EN) material. Both pumps were used for 15 months, then

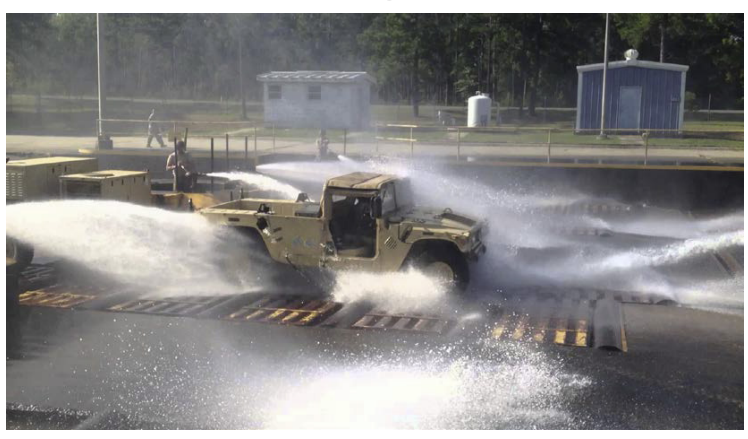
disassembled and inspected. No significant corrosion degradation of pump components was observed on either pump. However, pump components coated using the EN process performed slightly better than those coated using the thermally sprayed alloy. The EN coating produced more uniform results and was less expensive, so it may be preferred by Directorates of Public Works (DPWs). The ROI for the EN coating is 2.59. Both coatings are conservatively estimated to double pump service life when compared with the previous pumps, but the lack of service records precluded a firm, data-driven prediction.

\section{Adam Smith. 2016. ERDC/CERL TR-16-11. Architectural Survey of Laramie Armory, Wyoming Army National Guard, http://acwc.sdp.sirsi.net/client/en_US/search/asset/1050847}

This document is an architectural survey of the armory that is used by the Wyoming Army National Guard and located in Laramie, WY. The Armory was constructed in 1959, and the Field Maintenance Shop was built in 1961.

Laramie Armory, showing main entry with bright-aluminum, plate-glass doors with sidelights, transom, and a brick detail wall.

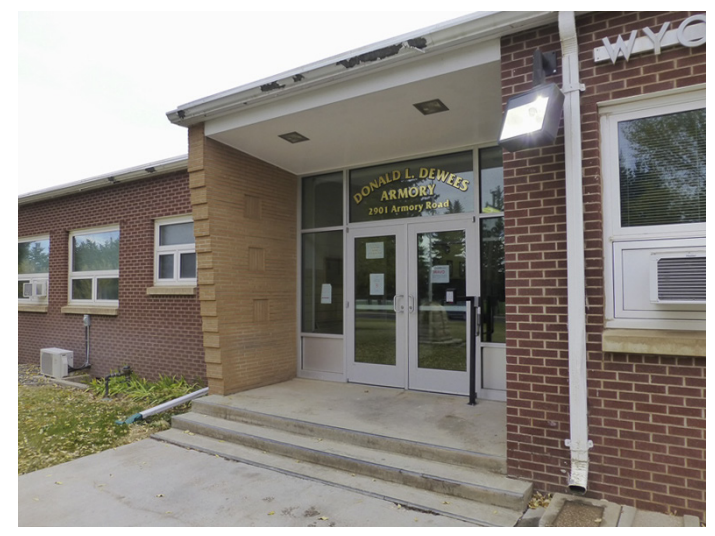

This survey satisfies Section 110 of the National Historic Preservation Act of 1966 as amended, and it was used to determine the eligibility of this armory for inclusion on the National Register of Historic Places (NRHP). This report recommends that the Laramie National Guard Armory is significant under NRHP criteria, and that it retains enough integrity to be individually eligible for the NRHP under Criteria A and C. 
Adam Smith. 2016. ERDC/CERL TR-16-12. NRHP Eligibility of the Fort Huachuca, Arizona, Elevated Water Tank (Facility 49001) and Reservoir (Facility 22020), http://acwc.sdp.sirsi.net/client/en_US/search/asset/1050908

This document is an assessment of NRHP eligibility of the Fort Huachuca, AZ, elevated water tank (Facility 49001) erected in 1941 and a reservoir (Facility 22020) constructed in 1959. The elevated water tank (Facility 4901) has remained generally unchanged except for different painting schemes. The demolition and reconstruction of the surrounding World War II temporary buildings makes this portion of the Fort Huachuca cantonment ineligible for the NRHP as a historic district. Although unchanged since its construction, the reservoir (Facility 22020) is not significant for construction technology. This survey

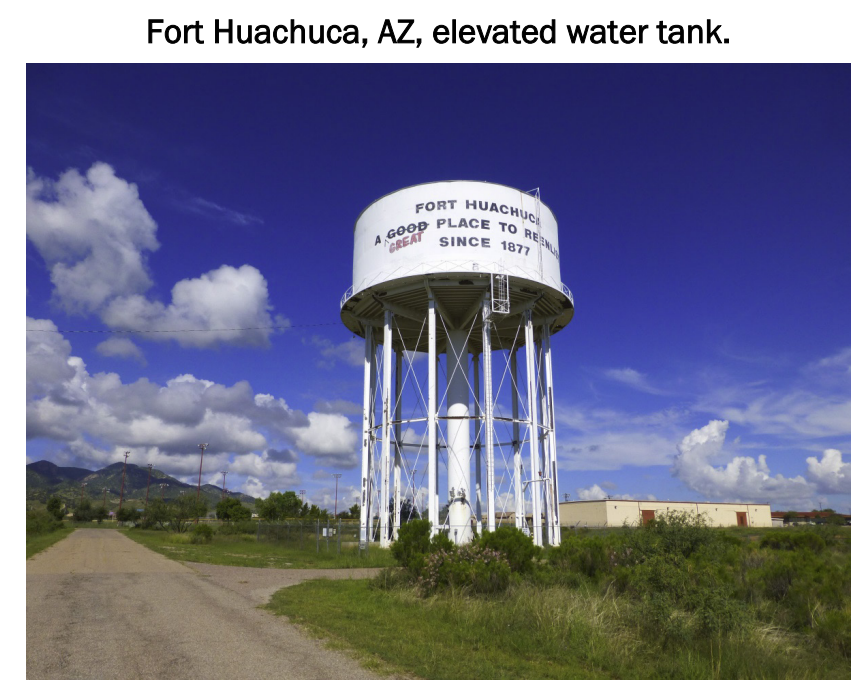
satisfies Section 110 of the National Historic Preservation Act of 1966 as amended, and was used to determine the eligibility of the elevated water tank under Section 106 of the National Historic Preservation Act of 1966 (NHPA) due to an undertaking, and the eligibility of the reservoir under Section 110 of the NHPA for inclusion on the NRHP. It is the recommendation of this report that the elevated water tank (Facility 49001) is not eligible to the NRHP since it is not individually significant and is not part of a larger historic district. The reservoir (Facility 22020) is individually not significant, and it is not part of a larger historic district.

Natalie R. Myers. 2016. ERDC/CERL TR-16-15. Assessing Socioeconomic Impacts of Cascading Infrastructure Disruptions Using the Capability Approach, http://acwc.sdp.sirsi.net/client/en_US/search/asset/1051046

U.S. Army doctrine requires that commanders understand, visualize, and describe the infrastructure component of the Joint Operating Environment to accomplish the Army's missions of protecting, restoring, and developing infrastructure. The functionality of modern cities relies heavily on interdependent infrastructure systems such as those for water, power, and 
transportation. Disruptions often propagate within and across physical infrastructure networks and result in catastrophic consequences. The reaction of communities to disasters may further transfer and aggravate the burden and facilitate cascading secondary disruptions.

Hence, a holistic analysis framework that integrates infrastructure interdependencies and community behaviors is needed to evaluate vulnerability to disruptions and to assess the impact of a disaster. The research for Human-Infrastructure System Assessment (HISA) for Military Operations adopts the Capability Approach (CA) to measure and predict the impact of potential infrastructural interdictions on the City of Maiduguri, Borno State, Nigeria. With the CA, 10 capabilities are identified to describe the wellbeing levels of Maiduguri. To quantify these 10

Capability of having access to electricity.

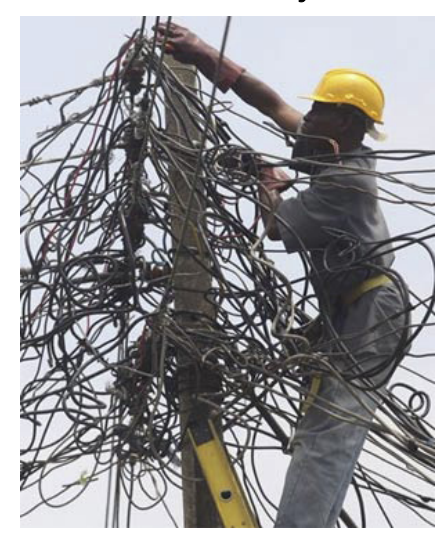
capabilities, 16 indicators were chosen to represent them. These indicator justifications provide the rationale for choosing the indicators for the corresponding capabilities and predictive modeling. Developing probabilistic predictive models of the indicators (or their indices) allows analysis of social well-being in relationship to cascading infrastructure failure.

Adam Smith. 2016. ERDC/CERL TR-16-17. Cultural Landscape Inventory for Picatinny Arsenal, New Jersey, http://acwc.sdp.sirsi.net/client/en_US/search/asset/1051607

This document presents a historic context, integrity analysis, and evaluation for the NRHP of the installation as a whole for Picatinny Arsenal, NJ. This work is a companion study to ERDC-CERL TR-16-4, which documented the cultural landscapes of the existing five historic districts. The report meets the requirements in NHPA for Federal agencies to address their cultural resources-defined as any prehistoric or historic district, site, building, structure, or object. Identification of

Bldg. 3250 (deemed eligible for the NRHP).

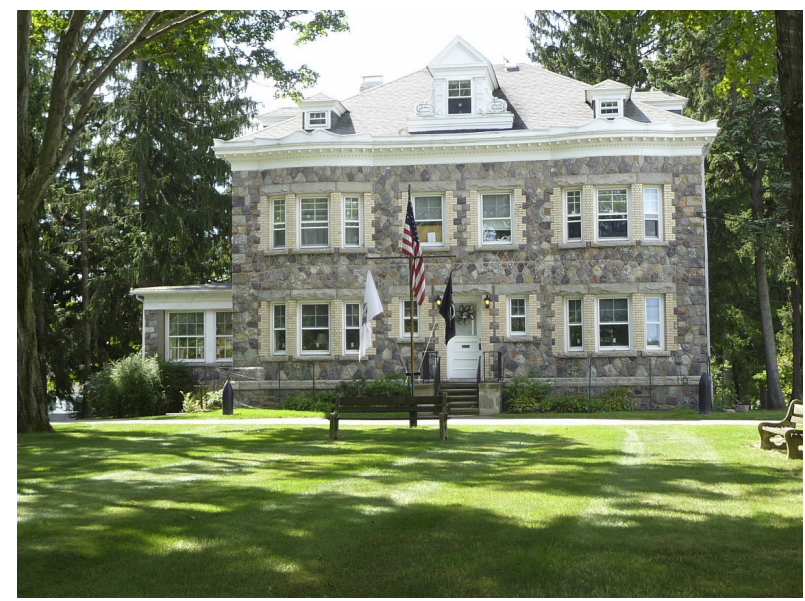


potentially significant properties is achieved only through a survey and evaluation to associate a property within a larger historic context.

Richard G. Lampo. 2016. ERDC/CERL TR-16-21. Demonstration and Validation of a Composite Grid Reinforcement System for Bridge Decks: Final Report on Project F12-ARO1, http://acwc.sdp.sirsi.net/client/en_Us/search/asset/1054386

The DoD maintains a large array of road networks that include vehicular bridges. Moving people, materials, and equipment is critical to the DoD mission. Many of these bridges are in dire need of major repairs or replacement due to corrosion and material degradation. The application of corrosion-resistant technology can extend the service life of bridges and reduce maintenance costs.

This DoD Corrosion PrevenSection of the 3-D Gridform reinforcement. tion and Control Program project demonstrated and validated the performance characteristics of the fiber FRP composite, three-dimensional Gridform product for reinforcing concrete bridge decks that was designed to solve many of the installation and life cycle problems associated with

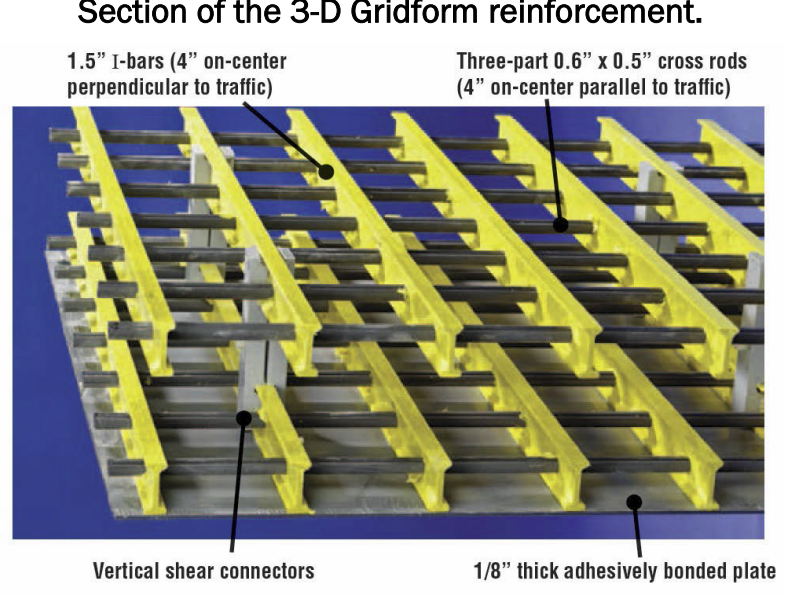
steel-reinforced bridge decks. The Gridform technology replaced the existing steel-reinforced concrete deck on one span of Bridge No. 4 at Fort Knox, KY. The newly replaced span's performance was compared to a second span that was newly replaced with a concrete deck using traditional steel rebar reinforcement. Structural testing and corrosion monitoring and analysis of the bridge was performed. Results show that using Gridform technology could provide needed load capacity and improved corrosion protection for DoD bridges, while maintaining structural capability. The technology's ROI is 10.31 .

Richard G. Lampo. 2016. ERDC/CERL TR-16-22. Demonstration of CorrosionResistant Hybrid Composite Bridge Beams for Structural Applications: Final Report on Project F12-AR15, http://acwc.sdp.sirsi.net/client/en_Us/search/asset/1054387

The Army has 1,500 vehicular bridges on its installations that can incur high maintenance costs and even early replacement as a result of corrosion 
of the steel support structures or the reinforcing bar in the concrete. The application of corrosion-resistant technology can extend the service life of bridges and reduce maintenance costs.

The Office of the Secretary of Defense Corrosion Prevention and Control Program project demonstrated and validated a corrosion-resistant hybrid composite beam (HCB) for the reconstruction of a one span of a traditional steel and concrete bridge at Fort Knox, KY. The HCBs were installed on half of the bridge, and conventional steel beams were installed on the other half. Structural analysis of the bridge was performed, and the span with HCBs was found to meet all design specifications and load ratings. This technology can increase the life cycle of bridge infrastructure when Ports for injecting self-consolidating concrete.

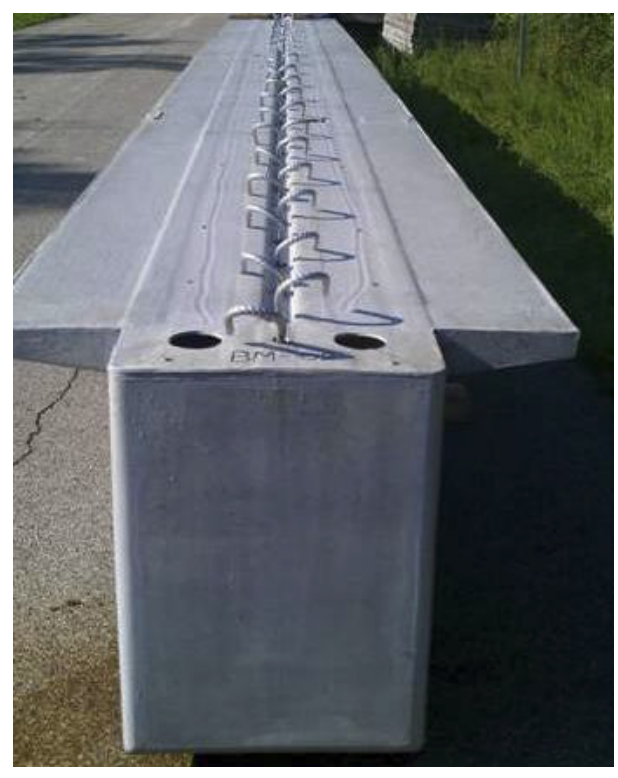
used in new construction and replacement by the Army and all other Federal agencies. The technology's ROI is 4.22 .

Mark S. Dorth. ERDC/EL CR-16-2. Modeling the Fate of Lead from Small Arms Firing Ranges, Fort Jackson, SC (Distribution F).

During studies associated with the Army's Operational Range Assessment Program (ORAP), Phase II, measured lead and copper concentrations in water and sediment exceeded the ecological protective action limit (PAL) at the entrance to Boyden Arbor Pond on Gills Creek. Boyden Arbor Pond is within, and adjacent to, the installation boundary of Fort Jackson. There is concern that these metals could become mobile and bioavailable to ecological receptors outside the installation boundary. The Small Arms Firing Ranges (SAFRs) within the Gills Creek watershed are the likely source of these metals. 
This study was conducted to evaluate the fate of lead residue that is deposited on the Fort Jackson SAFRs and to evaluate potential range management strategies for reducing lead concentrations in Boyden Arbor Pond. The Training Range Environmental Evaluation and Characterization System (TREECS $^{\mathrm{TM}}$ )

(http://el.erdc.usace.army.mil/treecs/) was used for this modeling. The model was calibrated against data col-

Gills Creek watershed.

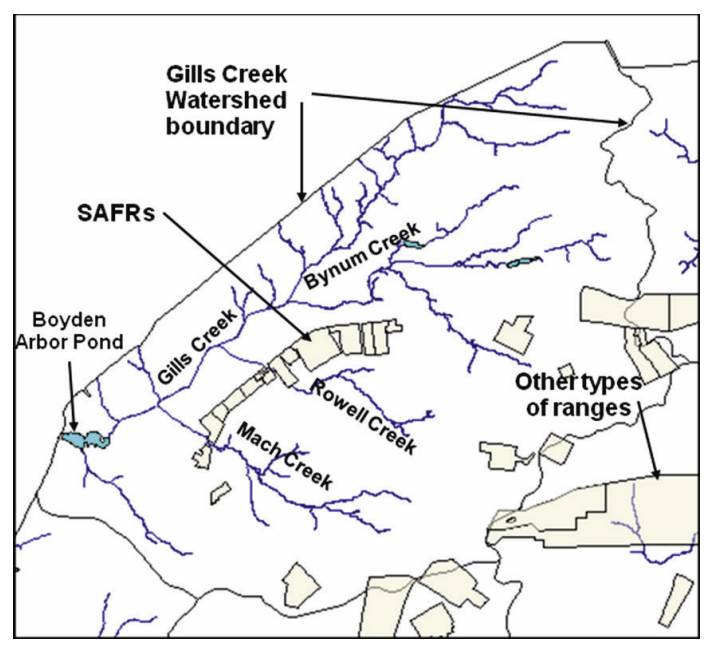
lected in 2009 and in 2014. Overall, the predicted concentrations for the calibrated model differed from those observed by a factor of 2.3, with a relative error of $54 \%$ or less. The best management practices evaluations support the theory that contributions of lead from soil interflow to receiving surface water over the next 75 years will be due to range use over the past 75 years, thus presenting a major challenge for development of a management alternative to meet the PAL for the next 75 years.

\section{Donna J. Schell. 2016. ERDC/CERL SR-16-4. The Department of Homeland Security Supplement to the Environmental Assessment and Management (TEAM) Guide.}

The number of environmental laws and regulations has continued to increase in the United States, and such growth makes compliance increasingly difficult. Environmental assessments have become an operationally consistent way to determine compliance with current environmental regulations. In 1984, CERL, now part of the Engineer Research and Development Center, began research that led eventually to the publication of TEAM Guide, based on Federal environmental regulations. This guide now is used by multiple Federal agencies to enhance consistency and accuracy in their environmental audit programs. In FY16, the Department of Homeland Security (DHS), which was already a partner in using the TEAM Guide, wanted a supplemental assessment tool to encapsulate DHS sustainability directives. The resulting manual is this Department of Homeland Security Supplement to The Environmental Assessment and Management (TEAM) Guide. 
Natalie Myers. 2016. ERDC TR-16-3. Understanding the Effects of Infrastructure Changes on Subpopulations: Survey of Current Methods, Models, and Tools, http://acwc.sdp.sirsi.net/client/search/asset/1050107

The Army's understanding of infrastructure as an operational variable has been evolving over the past 30 years in response to significant events that range from international conflicts to domestic weather-related disasters. These experiences have combined to drive a significant shift in infrastructure doctrine, which now demands that commanders and staff understand, visualize, and describe the infrastructure variable to accomplish the Army's assigned missions of protecting, restoring, and developing infrastructure, all of which are missions essential to restoring stability after conflict or disaster.

Current Army doctrine, however, does not say how commanders and staffs are to approach these challenging tasks. This report provides a focused examination of existing infrastructure assessment methods, models, and tools relevant to commanders' and staffs' growing need for $\mathrm{u}$ sing a holistic analytical capability regarding infrastructure.

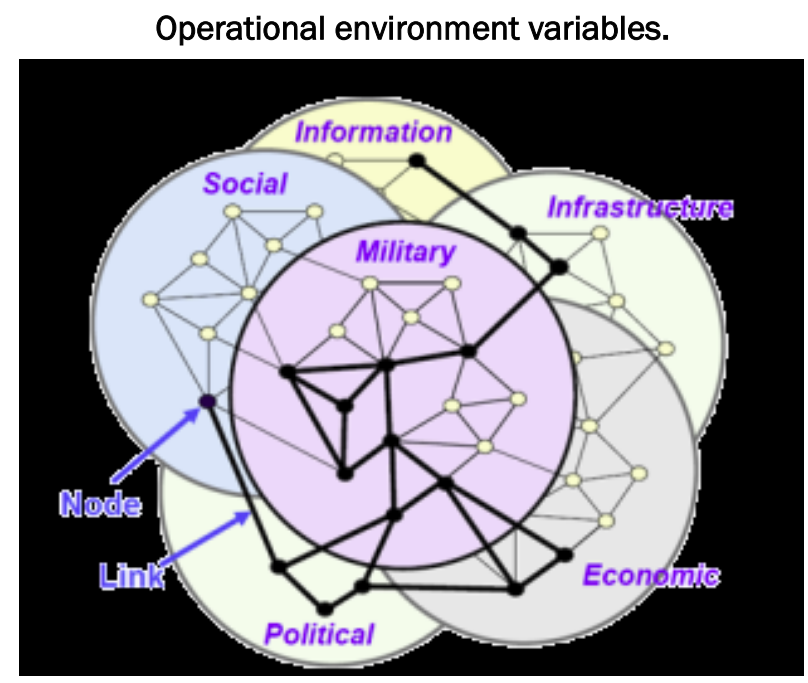

Adam D. Smith. 2016. ERDC/CERL TR-16-4. Cultural Landscape Analysis of Existing Historic Districts: Picatinny Arsenal, New Jersey, http://hdl.handle.net/11681/20205

This study documents the cultural landscape at Picatinny Arsenal, focusing on five existing historic districts. This work looks at the historic development and discusses the existing conditions within each of the five districts. It analyzes the features within each district for their historic significance and integrity, and based on this analysis, makes treatment recommendations. This document meets the requirements for Federal agencies to address their cultural resources that are defined as any prehistoric or historic district, site, building, structure, or object. Especially relevant is Section 110 of the NHPA, which requires Federal agencies to inventory and evaluate their cultural resources. 


\section{Sustainable Contingency Basing}

This focus area relates to identification of the Army's required capabilities for full spectrum contingency operations. To meet the objectives of this focus area, a multi-disciplined approach is necessary to develop solutions that ensure sustainability and efficiency while eliminating redundancy in a contingency environment.

Charles T. Decker, Andrew C. Johannes, Jed B. Alvey, et al. ERDC/CERL TR-1630. Opportunities for Waste Heat Recovery at Contingency Bases, https://erdc-library.erdc.dren.mil/xmlui/bitstream/handle/11681/20652/ERDC-CERL\%20TR-1630.pdf? sequence $=1$ \&isAllowed $=y$

The energy requirements of Contingency Bases (CBs) involved in U.S. military operations on every continent are met almost exclusively with the use of diesel generators, which are relatively inefficient both in terms of fuel consumption and the large amounts of waste energy generated during their operation. Tactical generators are currently loaded only to 30 to $40 \%$ capacity, due in large part to the sizing of generators to cover large electrical loads like electric heating of space and water. This work was undertaken to estimate the amount usable of available waste heat that could be captured and reused to heat buildings and provide hot water while reducing generator fuel

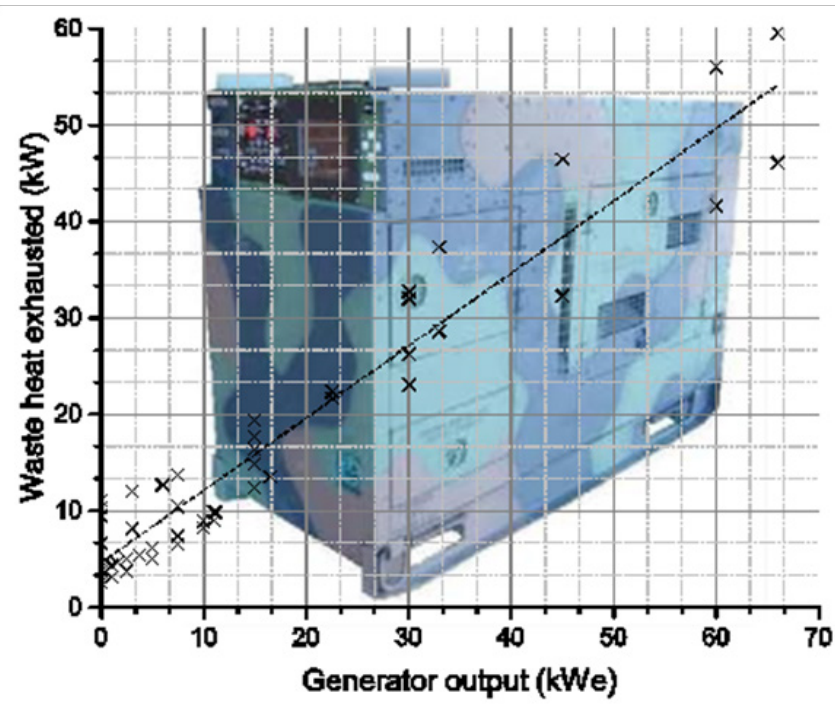
demand. It was found that the use of otherwise wasted thermal byproduct of the diesel generator for space and water heating allows loads to be consolidated so the numbers and sizes of generators can be dramatically reduced. The use cogeneration can lead to total fuel savings of nearly $20 \%$ Waste heat from five $60 \mathrm{~kW}$ generators can supply water heating for an entire 300 personnel contingency base, and in austere conditions, up to 1.75 gpm per implementation. 
Natalie Myers. 2016. ERDC TR-16-11. Assessing Socioeconomic Impacts of Cascading Infrastructure Disruptions in a Dynamic Human-Infrastructure Network, http://acwc.sdp.sirsi.net/client/en_uS/search/asset/1050668

The functionality of modern cities relies heavily on interdependent infrastructure systems such as those for water, power, and transportation. Disruptions often propagate within and across physical infrastructure networks and result in catastrophic consequences. The reaction of communities to disasters (e.g., seeking alternatives) may further transfer and aggravate the burden on surviving infrastructures, which may facilitate cascading secondary disruptions. Hence, a holistic analysis framework that integrates infrastructure interdependencies and community behaviors is needed to evaluate a city's vulnerability to disruptions and to assess the impact of a disaster. U.S. Army doctrine requires that commanders understand, visualize, and describe the infrastructure component of the Joint Operating Environment to accomplish the Army's missions of protecting, restoring, and developing infrastructure. To this end, a game-theoretical equilibrium model has been developed in a multilayer infrastructure network, to systematically investigate the mutual influence between the infrastructures and the communities. In this model, two types of infrastructure failure patterns are formulated to capture general network interdependencies; network equilibrium is extended into infrastructure and community systems to address redistribution of demand for life-supporting resources; the societal impact of disasters is estimated based on resource demand loss, cost increase, and total infrastructure failure. A real-world case study was implemented to demonstrate the proposed model and algorithm, and to reveal insights.

\section{William Brown, III. 2016. ERDC/CERL CR-16-2. SMART Energy Efficient Deployable Shelters (SEEDS). Distribution D.}

Energy plays a major role in the operation of Forward Operating Bases (FOBs) in a contingency environment. The basic building block for initial facilities/deployed shelters is the (Army) Force Provider system and (Air Force) Basic Expeditionary Airfield Resources (BEAR) Order of Battle (BOB); each shelter has an environmental control unit (ECU). The shelter ECUs consume over $70 \%$ of the electricity generated on FOBs. To meet their intensive energy needs,

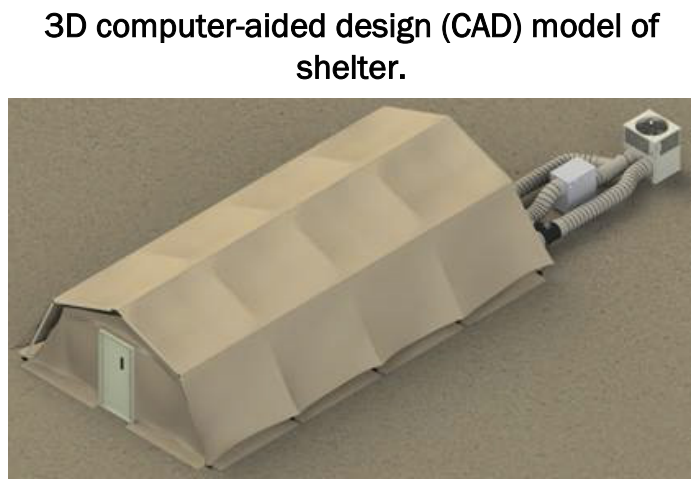


FOBs rely heavily on convoyed or air-dropped fuel, which represents a security risk and great operational expense. Attacks on delivery mechanisms for energy supplies in Afghanistan and Iraq demonstrate that fuel-inefficient FOBs that require excessive resupply endanger troops and threaten the mission. To improve shelter thermal efficiency to reduce ECU electricity consumption and effectively reduce the total fuel consumption on FOBs and the associated logistical requirements to meet those needs, this effort: (1) refined a computational fluid dynamics (CFD) shelter model, (2) used CFD simulations to evaluate the impact of improved shelter technologies on shelter thermal performance, and (3) integrated the selected technologies into an advanced shelter design. The developed advanced shelter will be field tested to verify the CFD simulation predicted thermal performance and reduction in energy consumption.

Kathryn A. Guy. 2016. ERDC/CERL TR-16-13. Novel Anaerobic Wastewater Treatment System for Energy Generation at Forward Operating Bases: Final Report on Environmental Restoration Project ER-2218, http://acwc.sdp.sirsinet/client/en_US/search/asset/1051006

FOBs currently lack sustainable wastewater treatment options, creating operational inefficiency, personnel vulnerability, and environmental degradation. The objective of this research was to develop a sustainable wastewater treatment system for FOBs that converts wastewater contaminants, including organics and ammonia, into harvestable products for enConceptual design for integrated Anaerobic-
Clinoptilolite-Electrolysis (ACE)wastewater treatment system.

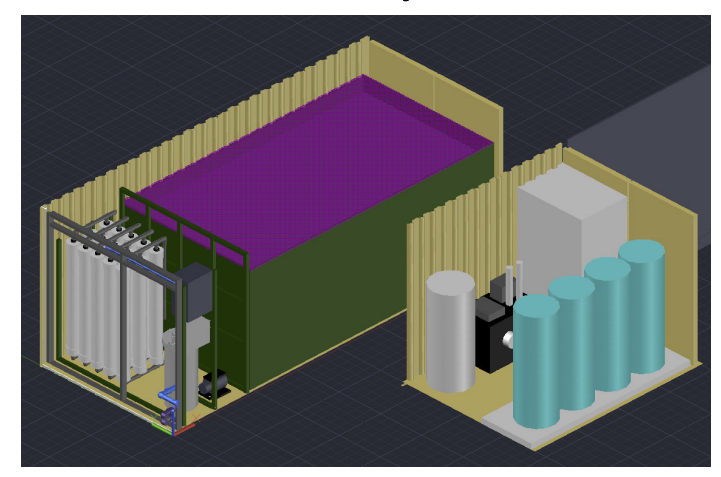

ergy production. The system aims to combine sustainable materials with recent technological advances to treat wastewater with minimal material input and reduced disposal issues, while producing a net return on energy. The wastewater treatment system designed under this project will benefit DoD by reducing the costs, logistical burden, and risks associated with wastewater management at FOBs. Further development of the technology into a full-scale unit is expected to yield an efficient system for onsite treatment that is simple to operate and produces fuels for electrical and thermal energy generation. This positive-net-energy approach will support self-sufficient-FOB 
design goals. The integrated system would also reduce the logistical burden and risks associated with transporting waste and importing fuel, chemicals, and water. The proposed system will reduce the FOB environmental footprint and impact on indigenous populations, demonstrating innovative and effective environmental stewardship.

\section{George Calfas. 2016. ERDC/CERL TR-16-14. Construction Material-Based Methodology for Military Contingency Base Construction: Case Study of Dhaka, Bangladesh, http://acwc.sdp.sirsi.net/client/en_Us/search/asset/1051267}

To sustain itself as the world's premier land power, the Army needs the capability to support expeditionary forces by projecting a minimal basing footprint with reduced logistical burdens. Strategically sited CBs allow the Army's expeditionary forces to rapidly respond and attack the enemy throughout the joint area of operations (JOA). Strategic conditions will be analyzed through the lens of eight operational energy (OE) variablespolitical, military, economic, social, Overlay of site selection construction material factors. information, infrastructure, physical environment, and time (PMESII-PT). The Army has neither a well-grounded methodology nor the tools that enable this strategic decision-making capability. Decision makers require reliable information about the situational dynamics of the operational environment to anticipate the impacts that siting and operating CBs will have on the local context, and to consider the effects of the sites on the operation of CBs. This capability to anticipate CB impacts and resources draws upon knowledge gleaned from the local population and becomes particularly important for engagement operations when CBs will have a longer duration of use and interaction with the local populace. This report considers access of building materials required for the construction of CBs and develops a methodology for strategically siting CBs that can be replicated 
in other locations throughout the world. This work then validates the developed methodology with a case study of Dhaka, Bangladesh.

Perkins. 2016. ERDC SR-16-3. Machine Classification of Text and the Detection of Dominant Political Narratives. Limited Distribution. FOUO.

The purpose of the Violent Events Sociocultural Analysis (VESCA) project is to improve the processing and exploitation of event data to enable a deeper understanding of operating environments. Work products include the processes and tools needed to develop and analyze an enhanced sociopolitical event data set. The work described in this report was undertaken to assess the feasibility of an approach to automating the identification of dominant political narratives in media reports for possible analysis in combination with event data. Dominant political narratives offer the potential to clarify the strategic and operational considerations that may influence tactical activities, and to understand the events that both frame the context for communication and explain how events may be interpreted or described. Results suggest that it is feasible to achieve "moderate agreement" in coding accuracy through human coding of dominant political narrative and yield reasonably accurate classification from machine automation based on that training. However, the effort is labor-intensive and methods need to be validated through further study. 


\section{Sustainable Natural Infrastructure}

The U.S. Army Corps of Engineers strives to protect, sustain, and improve the natural and manmade environment of the Nation, and is committed to compliance with applicable environmental and energy statutes, regulations, and Executive Orders. The Corps of Engineers is committed to ensuring that sustainability is not only a natural part of all our decision processes, but should also part of our organizational culture. The Corps, which is a steward for some of the Nation's most valuable natural resources, strives to ensure sustainable solutions that address short and long-term environmental, social, and economic considerations.

The purpose of this focus area is to engage stakeholders through forums, white papers, publications, and other means regarding DoD-related concerns with natural resources, both in terms of managing DoD assets and natural resources as they relate to international and national security and stability.

Nathan R. Beane. 2107. ERDC/CERL TR-17-09. Geopolymer Soil Stabilization at Sierra Army Depot, http://dx.doi.org/10.21079/11681/22553

Vegetation and soil conditions were evaluated prior to, and following herbicide application implemented to control woody vegetation and maintain open grassland areas at Fort Hood, TX. Herbicide application resulted in a decreased rate of vegetation resprout compared with areas where herbicide was not used. Specifically, herbicide mixtures containing Remedy Ultra and Methylated Seed Oil (RU-MSO) outperformed treatments in which no herbicide was applied and areas receiving herbicide and diesel fuel oil treatments (RU-diesel) across each of the three soils evaluated. Field monitoring assessed herbicide concentrations in soil and water. Herbicides were not observed in creeks and ponds adjacent to treatment areas. In soils, herbicide concentrations decreased by $72 \%$ over one month, likely due to microbial degradation, and with distance

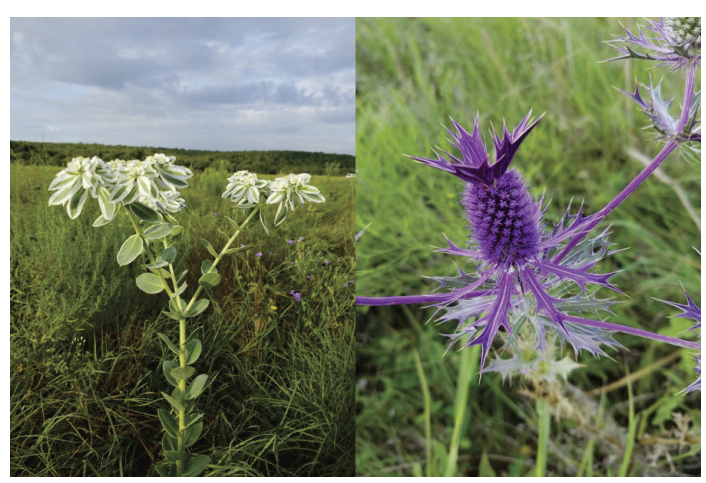

Herbs, snow-on-the-prairie (Euphorbia bicolor) (left) and Leavenworth's eryngo (Eryngium leavenworthii) (right), in full display within a grassland community at Fort Hood, Texas. 
from the point of application. Monitoring results suggest that limited lateral and/or vertical transport occurred under field conditions. Laboratory studies evaluated potential fate and transport of herbicide compounds, identifying herbicide affinity for the soil surface. Additionally, RU-MSO treatments were strongly bound to soil surfaces at environmentally relevant concentrations. Further, laboratory column studies also suggest that potential transport in soil remained limited. Incorporating periodic herbicide applications into an integrated vegetation management plan will maintain grassland habitats in support of the mission.

\section{David S. Davis. 2017. ERDC/EL CR-17-01. Elders Point East Marsh Island Restoration-Monitoring Data Analysis, http://dx.doi.org/10.21079/11681/23952}

Chronic loss of intertidal salt marsh island habitat in Jamaica Bay, New York, has led to efforts by multi-agency partnerships to reduce loss through habitat restoration. A 2006 USACE New York District report recommended restoration of three marsh islands within the Jamaica Bay Unit of Gateway National Recreation Area: Elders Point East, Elders Point West, and Yellow Bar Hassock. USACE New York District and its local sponsor, the Port Authority of New York and New Jersey, utilized sand obtained from navigation dredging and commercial sources to: (1) return approximately 16 hectares (40 acres) of bay area to full Spartina alterniflora marsh and wetland functionality, and (2) test a suite of management practices to enhance the probability of long-term success. Although the longterm success of the Elders Point East Marsh restoration project cannot be confirmed by the 2007-2012 term of post-construction monitoring, nearly

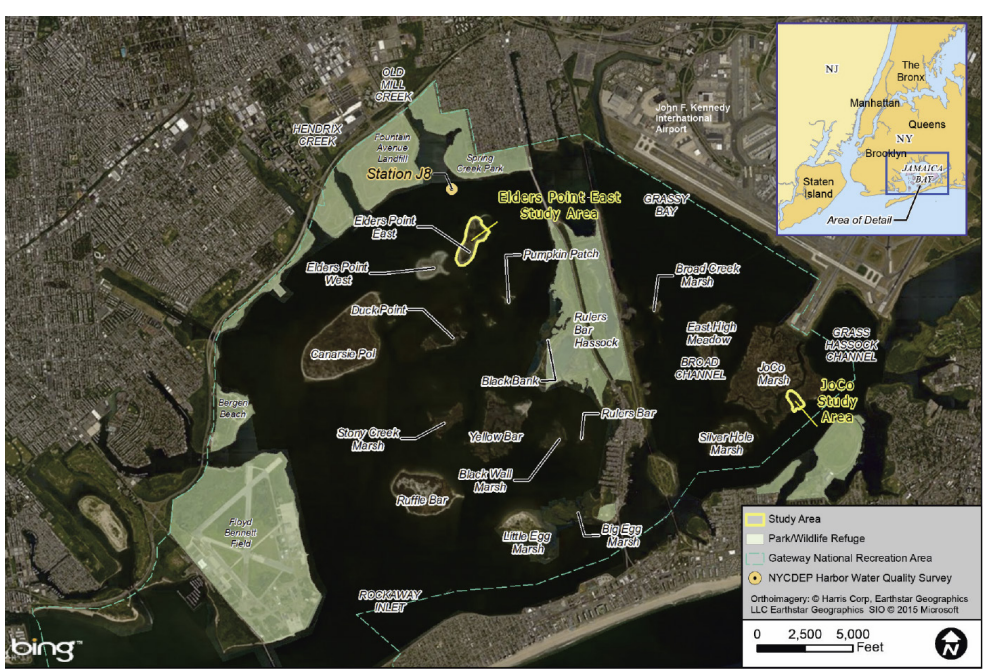

Jamaica Bay overview map. all lines of evidence gathered to date indicate that the marsh is following a functional equivalency trajectory toward an endpoint comparable to reference conditions. In this case, the beneficial use of dredged material 
proved to be a viable option for restoration of sufficient habitat area to substantially enhance lost ecological function within the Jamaica Bay ecosystem.

\section{Anna E. Steel. 2017. ERDC/EL TR-17-10. Two-Dimensional Movement Patterns of Juvenile Winter-Run and Late-Fall Run Chinook Salmon at the Fremont Weir, Sacramento River, CA, http://dx.doi.org/10.21079/11681/22766}

To improve modeling of juvenile salmon behavior and movement in the Sacramento River, smaller winter-run Chinook and larger late-fall-run Chinook salmon were tagged and released into a 2D telemetry array during the winter of 2015. Detection positions were filtered and discretized to create two-dimensional tracks and measure movement characteristics, evaluate space use, and assess whether these runs displayed distinct behavioral differences. Speed over ground and turning angle were not significantly different between release times, fish size, or run. Only the initial movement rate between release and array locations was significantly different between the runs. Both runs displayed a non-uniform distribution within the channel and tended to use space along the outer bend more frequently than the inner bend. Winter-run Chinook salmon tracks were slightly farther towards the outer bend than late-fall-run Chinook. A similar result was not observed in smaller and larger late-fall-run Chinook, which suggested that differential space use may be influenced more by run identity than variation in size between runs. Although small differences between runs were measured, it is reasonable to aggregate these results for a singular juvenile salmon behavior model, rather than developing independent juvenile behavior models based on adult run-timing.

Michael P. Guilfoyle. 2017. ERDC/EL TR-17-12. Documenting Presence and Movements of Piscivorous Birds along the Illinois River and within the Chicago Area Waterway System, http://dx.doi.org/10.21079/11681/22783

This technical report summarizes research conducted on piscivorous birds along the Illinois River and in the Chicago Area Waterway System (CAWS) to assess the potential role of these birds as vectors of invasive carp (bighead carp (Hypophthalmichthys noblis) and silver carp (H. molitrix)) 
DNA (deoxyribonucleic acid). To prevent these carp from invading the Great Lakes, the U.S. Army Corps of Engineers has spent considerable time and resources constructing electrical barriers in the Chicago Sanitary and Ship Canal around Romeoville, IL, just south of the Chicago metropolitan area. Since the construction of these barriers, intensive monitoring of fish populations and invasive carp environmental DNA (eDNA) have been used to document the possible presence of carp above the barrier. The Asian Carp eDNA Calibration Study (ECALS) was designed to improve our understanding and interpretations of eDNA monitoring efforts in the Chicago Area Waterway System (CAWS). Existing online bird population data sources were analyzed, and 30 Double-Crested Cormorants (Phalacrocorax auritus) were captured and satellite-tagged. The results from these projects are evidence that piscivorous birds are likely contributing at least in part - to the presence of invasive carp DNA in the Chicago Area Waterway System.

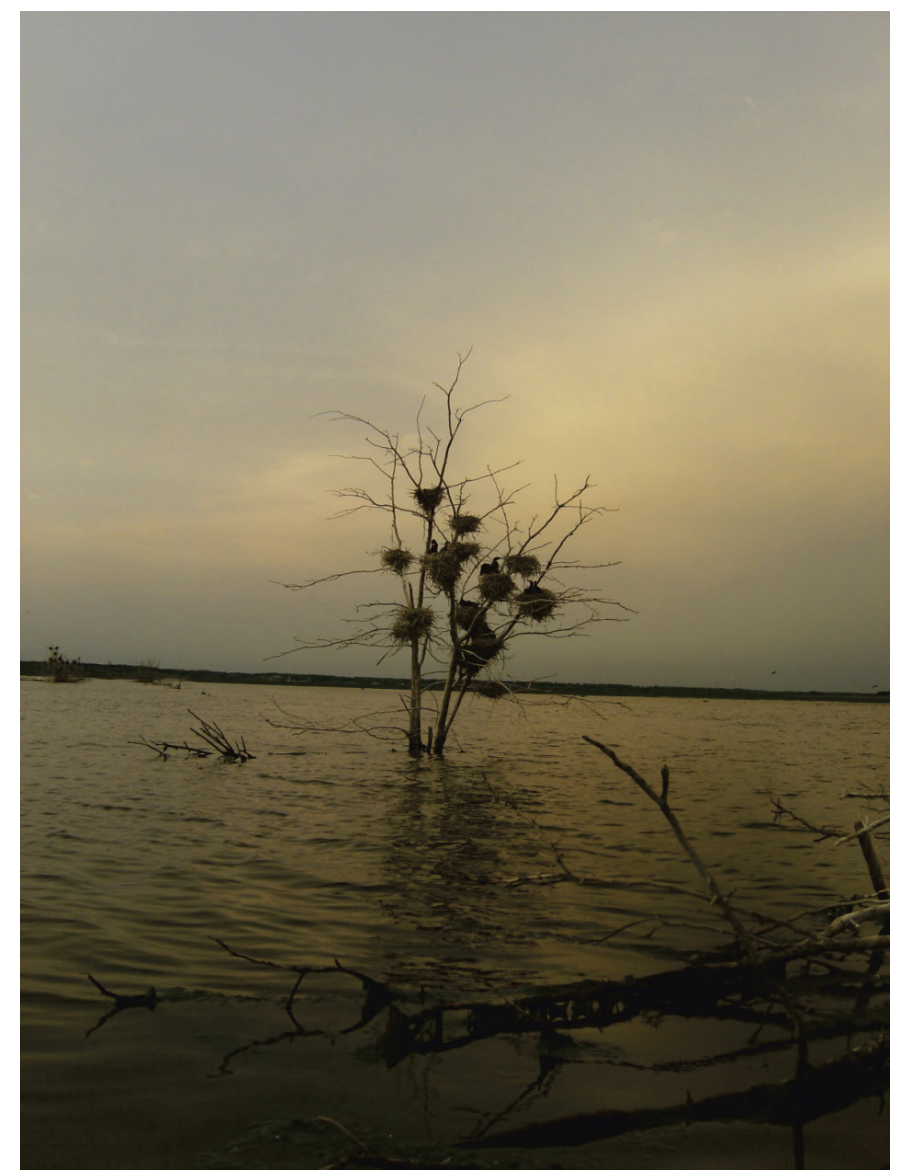

One of several small Double-Crested Cormorant nesting sites found within TNC Emiquon Preserve, near Havana, IL (about 70 $\mathrm{km}$ south of Peoria, IL). 
Glenn M. Suir. 2017. ERDC/EL TR-17-15. Floristic Quality Index of Restored Wetlands in Coastal Louisiana, http://dx.doi.org/10.21079/11681/22930

Restoration efforts in the United States have created or benefitted large expanses of wetlands. Typical goals of wetland restoration efforts are to conserve, create, or enhance wetland form and to achieve wetland function that approaches natural conditions. Measures of wetland condition have been used to monitor and assess project performance, resilience, and adaptive management needs. An emerging tool for performing bioassessments in wetland systems is the Floristic Quality Index (FQI). This study assessed the use of a modified FQI (FQImod) to evaluate site development, plant community establishment, and wetland condition. Three restoration sites in coastal Louisiana were used to evaluate the utility of an FQImod for assessing the performance and resilience of restored wetlands by comparison to reference wetlands. Results demonstrate that the FQImod data successfully reflected large disturbance events - namely hurricanes and salinity

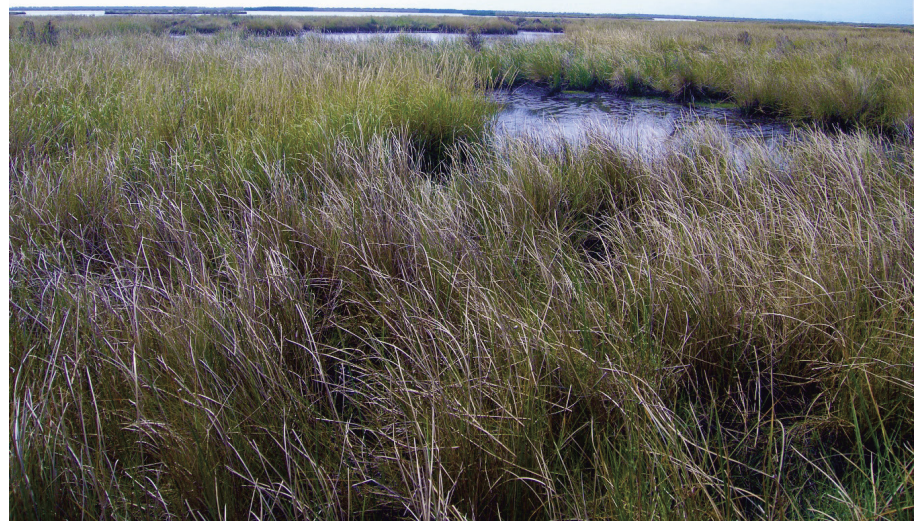
spikes. The data also identified vegetation differences due to elevation, age, and hydrology. The modified FQI provided useful measures of restoration type (e.g., planted versus not planted, marsh creation versus nourishment), chronosequence (condition and stability over time), and trajectory (i.e., intersecting trend lines when restored marsh FQI approaches reference marsh condition). The FQImod provides a rapid and effective system for assessing wetland condition and performance.

Mark S. Dortch. 2017. ERDC/EL TR-17-08. User Guidance for Application of TREECS ${ }^{T M}$ and CTS for Environmental Risk Assessment of Contaminants on Department of Defense (DoD) Ranges, http://dx.doi.org/10.21079/11681/22650

The Training Range Environmental Evaluation and Characterization System (TREECS ${ }^{\mathrm{TM}}$ ) was developed for the Army to forecast the fate of and risk from munitions constituents (MC), such as high explosives and metals, within and transported from firing/training ranges to surface water 
and groundwater. TREECS ${ }^{\mathrm{TM}}$ requires chemical-specific properties as part of the inputs. The Chemical Transformation Simulator (CTS) was developed by the U.S. Environmental Protection Agency (USEPA) to provide physicochemical properties of complex organic chemicals. The CTS has capabilities for estimating chemical-specific properties in the absence of experimentally obtained properties; thus, CTS can help fill data gaps for properties, particularly for emerging $\mathrm{MC}$ that have limited experimental data. This report discusses the input requirements, sources of input data, and lessons learned from applying TREECS ${ }^{\mathrm{TM}}$ and CTS.

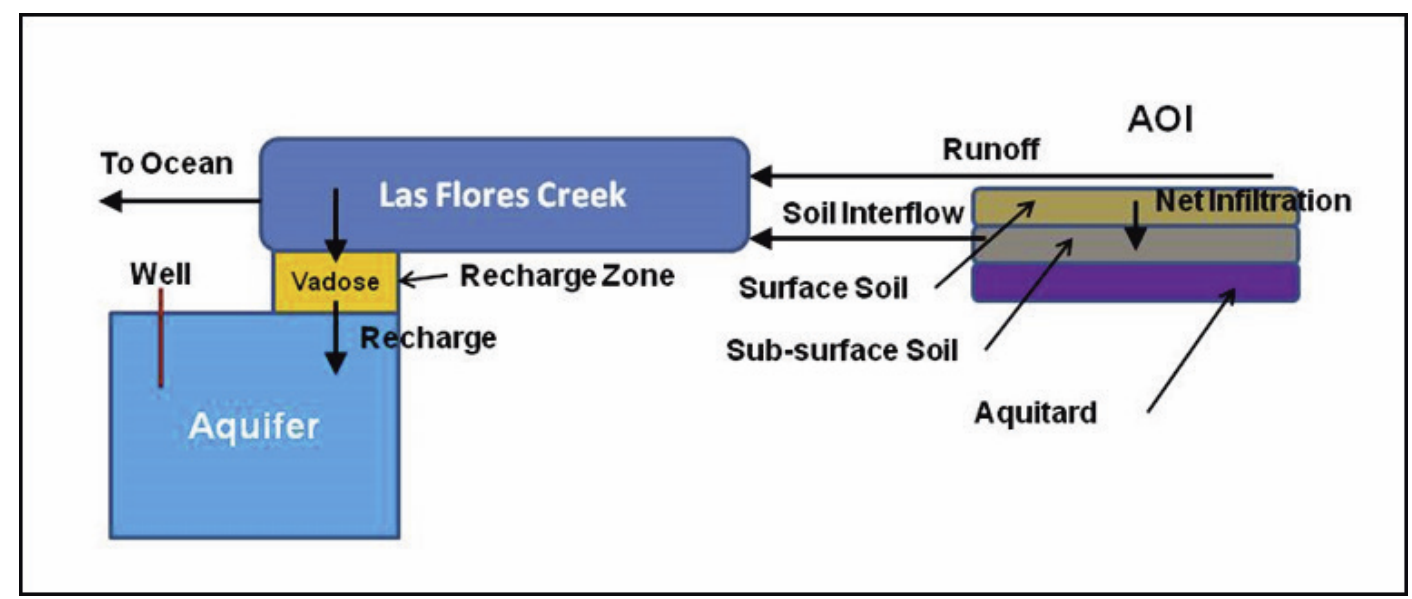

Contaminant Simulation Module (CSM) for modeling Zulu Impact Area and receiving waters, Marine Corps Base [Camp] (MCB) Camp Pendleton, CA.

Kevin Philley. 2017. ERDC/EL TR-17-16. Lake Aquilla Habitat Survey Hill County, Texas, http://dx.doi.org/10.21079/11681/22929

This study surveyed and mapped the plant communities at Lake Aquilla, Hill County, TX. The condition of the communities and their potential for future applications of selected restorative practices were also evaluated. Emphasis was placed on locating potential Texas Blackland prairie remnants, shrublands that may support the federally threatened Black-capped vireo (Vireo atricapilla Woodhouse), and oak-juniper woodlands that may support the federally endangered Golden-cheeked Warbler (Dendroica chrysoparia P. L. Sclater and Salvin). Data was collected using a combination of plots and transects. All vascular plant species were recorded, as well as their abundance and growth form. Plant community classifications were adapted from those developed by the National Vegetation Classification System for the state of Texas. Thiswork recorded 227 species of vascular plants from 27 sample locations. Remnant patches of Texas Blackland prairie degraded by fire suppression and previous land use practices were identified in the survey area. Shrublands suitable for the black-capped 
vireo, and oak-juniper woodlands suitable for the golden-cheeked warbler were not detected in the survey area. Restorative practices that include management of undesirable woody vegetation and application of prescribed fire were recommended for the grasslands, and oak woodlands and forests at Lake Aquilla.

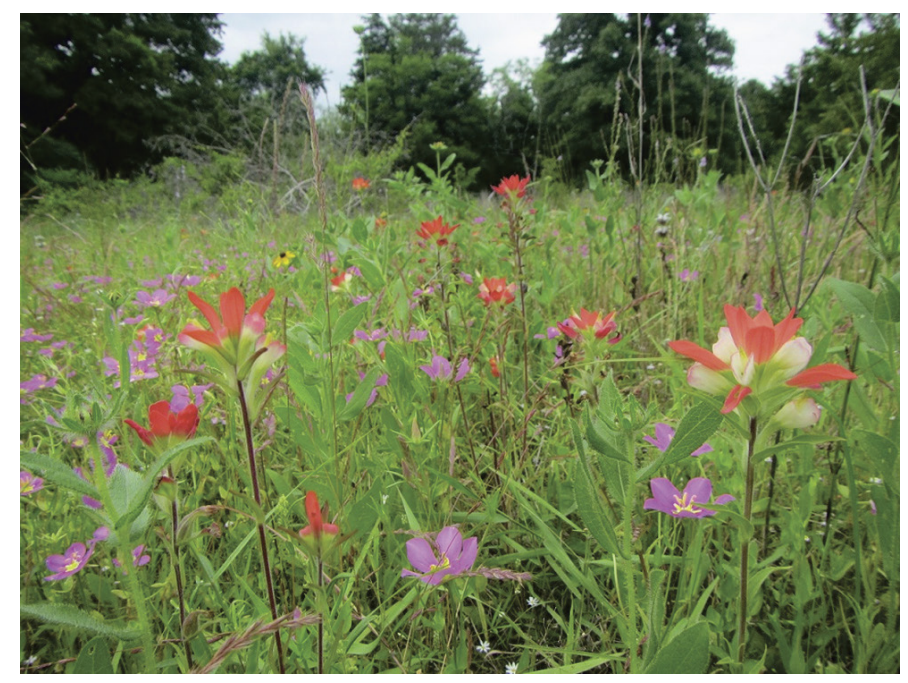

Site photo from LA05, Lake

Aquilla, TX, with Indian paintbrush and Texas star in the foreground.

Guilherme R. Lotufo, 2017. ERDC/EL TR-17-17. Review and Synthesis of Evidence Regarding Environmental Risks Posed by Munitions Constituents (MC) in Aquatic Systems, http://dx.doi.org/10.21079/11681/25402

Underwater military munitions (UWMM) may pose a risk to aquatic environments because they typically contain munitions constituents (MC) such as 2,4,6-trinitrotoluene (TNT) and hexahydro-1,3,5-trinitro-1,3,5-triazine (RDX). If UWMM become corroded or breaches, the fill material may leak or dissolve into the surrounding environment, which could potentially adversely affecting affect the exposed biota. In large part, because of the high cost and complexity associated with sampling MC at UWMM sites, detailed and reliable information about MC in water, sediment, and biota is available for only a few sites, and therefore temporal and spatial uncertainties persist. Examination of available data indicates that concentrations of $\mathrm{MC}$ in water and sediment were largely below detection or were relatively low (e.g., parts per billion), with higher concentrations being highly localized and typically near a point source. These findings were in accordance with predictive modeling and with fate studies. Available toxicity data derived for a variety of freshwater and marine species were compiled and used to derive interim water quality criteria and protective values derived from species sensitivity distributions. 


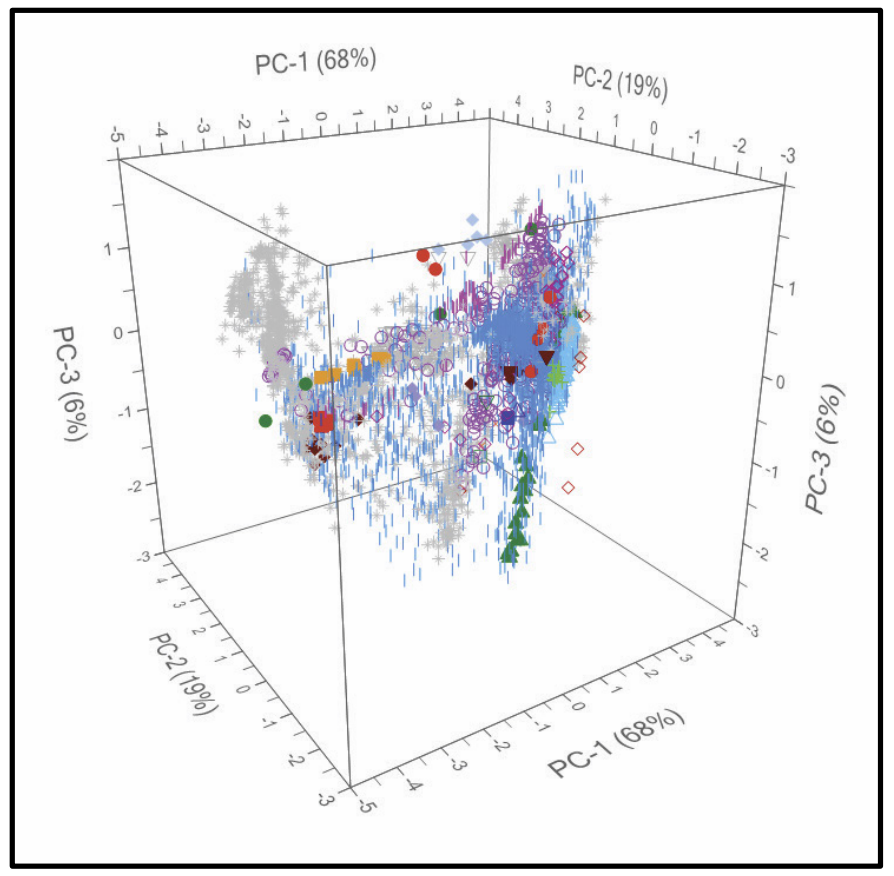

Toxicity varied widely across a diversity of $\mathrm{MC}$ and species. For most aquatic sites, $\mathrm{MC}$ contamination in sediment and in the water-column presents low risk to the resident biota.

Three-dimensional representation of PC 1-3 from a multivariate decomposition of the SedDB characterization data.

\section{Benjamin E. Barrowes. 2016. ERDC/CRREL TR-16-12. Evaluation of Electromagnetic Induction (EMI) Resistivity Technologies for Assessing Permafrost Geomorphologies, http://acwc.sdp.sirsi.net/client/en_US/search/asset/1050886}

Effective and efficient mapping of permafrost subsurface composition at scales relevant to the design and maintenance of horizontal and vertical infrastructure has been a long-standing challenge. Of utmost utility would be the development of standoff measurement techniques that could discern at the meter to submeter spatial scale and up to $10 \mathrm{~m}$ into the subsurface the presence or absence of ice features. Groundbased geophysical measurement techniques, including groundpenetrating-radar, borehole logging, and electrical resistivity, have been used to interrogate the subsurface in permafrost terrains at the meters to kilometers scales. Airborne measurement techniques have broad applicability at

EMI instrument conceptual operation. The primary fields (red) produce secondary fields (blue) that are detected by the receiver coil.

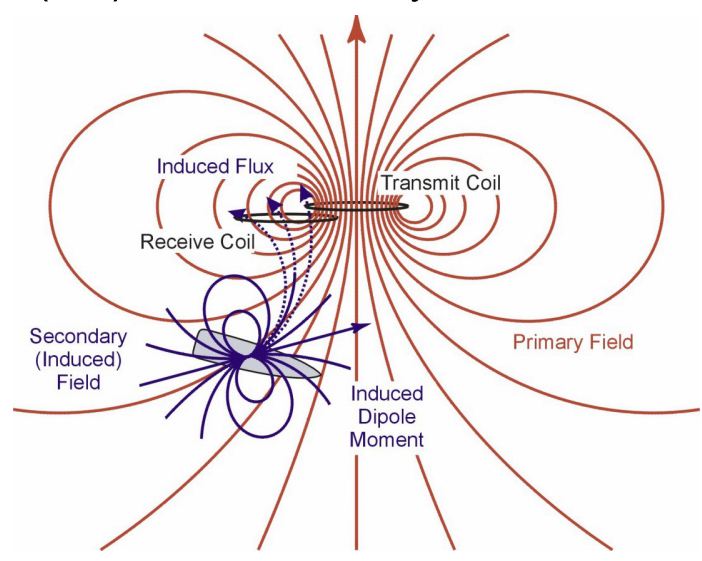


the larger, kilometers to tens of kilometers scale and could support linear infrastructure development and terrain mapping. However, there is a broad need for cost effective airborne geophysical techniques to obtain high-resolution measurements of specific areas of interest. This report explores the potential application of airborne EMI methods for the investigation and mapping of permafrost and reviews current ERDC EMI survey capabilities and new opportunities, including the development of a new medium-scale autonomous EMI instrument.

\section{Matthew Hohmann. 2016. ERDC/CERL TR-16-31. A Species Distribution Modeling Informed Conservation Assessment of Bog Spicebush, http://acwc.sdp.sirsi.net/client/en_US/search/asset/1054548}

Bog Spicebush (Lindera subcoriacea) is a DoD Species at Risk (SAR) that has recently been proposed for listing under the Endangered Species Act. Roughly $60 \%$ of all known Bog Spicebush populations are found on five DoD installations: Fort Bragg, Camp Mackall, Fort Jackson, Eglin Air Force Base (AFB), and Camp Shelby Joint Forces Training Center (JFTC). This recently described species has been reported to occupy a variety of plant communities that have varying disturbance dependence, suggesting the habitat suitability of occupied sites is spatially and temporally dynamic.

Additional information about Bog Spicebush habitat requirements and potential distribution is needed to inform assessments of the species' conservation status and management needs. This project used MaxEnt, a widely applied species distribution modeling approach to generate a range-wide habitat suitability map. This map was also used to identify: (1) sites warranting targeted surveys for novel populations, (2) suitable habitat for conservation and management, and (3) sites suitable for population (re)introduction.

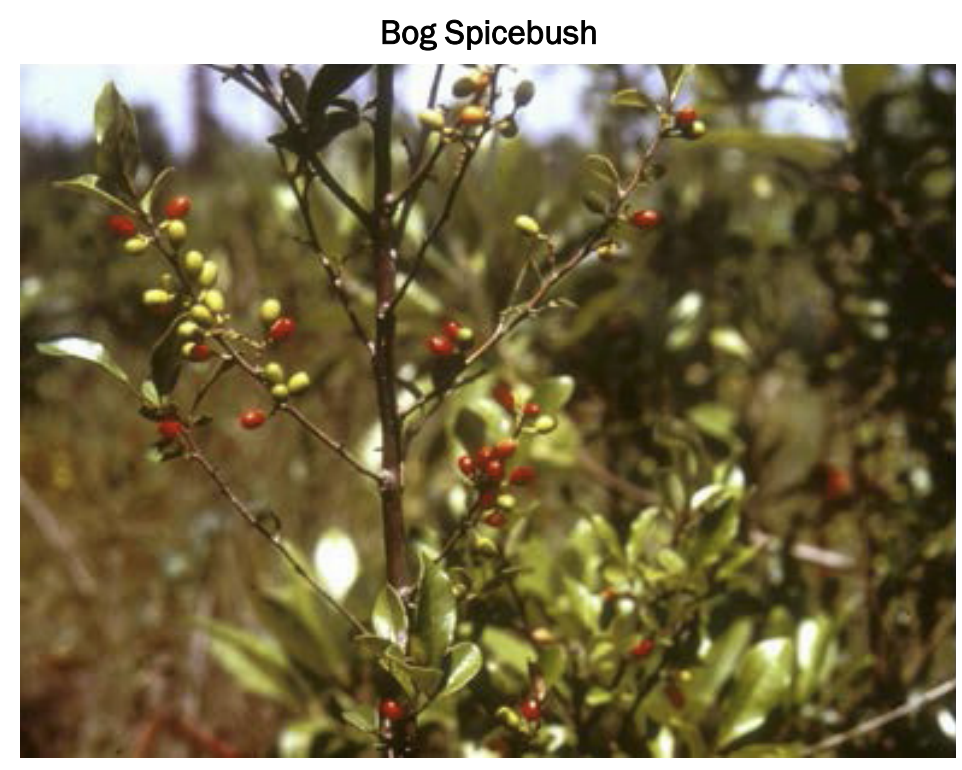


Matthew K. Mersel. 2016. ERDC/CRREL SR-16-5. Synthesizing the Scientific Foundation for Ordinary High Water Mark Delineation in Fluvial Systems, http://acwc.sdp.sirsinet/client/en_US/search/asset/1054567

For more than 100 years, the ordinary high water mark (OHWM) has been used to define water boundaries in a number of contexts in the United

An anabranching portion of the Yukon River in central Alaska.

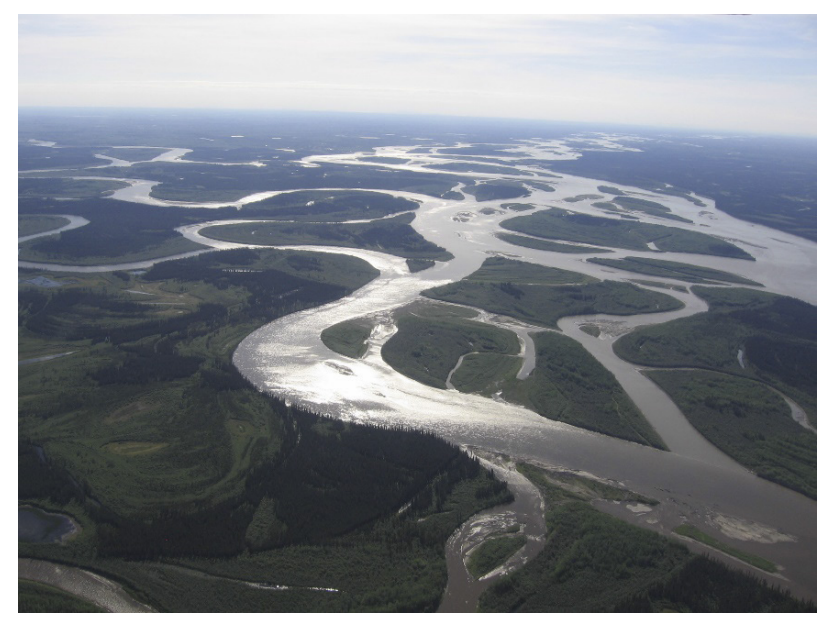

States. This Special Report summarizes the scientific literature pertaining to the indicators used to identify the OHWM in fluvial systems, building on more than a decade of research and publications related to the OHWM in the ongoing process to implement the Clean Water Act and the Rivers and Harbors Act of 1899. This report does not change or redefine the indi-

cators used to identify the OHWM, nor is it a manual for how to delineate the OHWM. This report first reviews established concepts in river science that relate to the OHWM then reviews various sources of information that can be used to delineate the OHWM, discusses geographic variations in OHWM indicators among river segments, reviews human activities that can affect the OHWM, and finally presents examples of the OHWM in diverse channel types and regions.

James H. Lever. 2016. ERDC/CRREL SR-16-4. Autonomous Sea-Ice Thickness Survey, http://acwc.sdp.sirsinet/client/en_US/search/asset/1050267

We conducted an autonomous survey of sea-ice thickness using the polar rover Yeti to tow an electromagnetic induction meter over sea ice in McMurdo Sound, Antarctica. This proof-of-concept survey aimed to demonstrate improved efficiency relative to
Yeti towing an EM31 electromagnetic ice-thickness meter along the Pegasus Cutoff Road near McMurdo Station, Antarctic.

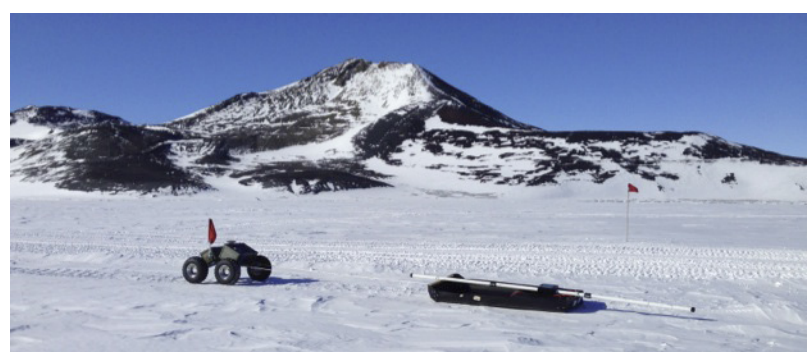


manual surveys routinely conducted to assess the safety of roads and runways constructed on the sea ice. Yeti executed the autonomous survey on 11 November 2014. This report describes the methods used, compares the measured ice-thickness profiles with manual borehole measurements, assesses the merits of autonomous surveys relative to manual ones, and describes potential future applications.

Steven Larson. 2016. ERDC/EL TN-16-2. Technology Transfer of Biopolymer Soil Amendment for Rapid Revegetation and Erosion Control at Fort A. P. Hill, Virginia, http://acwc.sdp.sirsi.net/client/en_US/search/asset/1049768

Sustainable land management at Army installations is a critical concern of the modern Army and the Army engineer. A unique soil additive consisting of a polysaccharide polymeric material, a natural product of plant/soil rhyzobial microbial activity, was demonstrated to enhance site vegetation and control erosion. The effort was supported by the DoD Environmental Security Technology Certification Program (ESTCP) Project ER-0920. Rhizobium tropici, a catalogued symbiotic nodulator of leguminous plants (Martinez-Romero et al. 1991), is also known for its prolific production of a gel-like, extracellular polymeric substance (EPS), a biopolymer. The natural functions of the EPS in the rhizosphere include surface adhesion, selfadhesion of cells into biofilms, formation of protective barriers, water retention around roots, and nutrient accumulation. The secretion of EPS by bacteria is recognized as a cohesive force in promoting surface erosion resistance in sediments.

Rapid seed germination evident at 7 days and significant biomass production at 3 weeks post-planting.

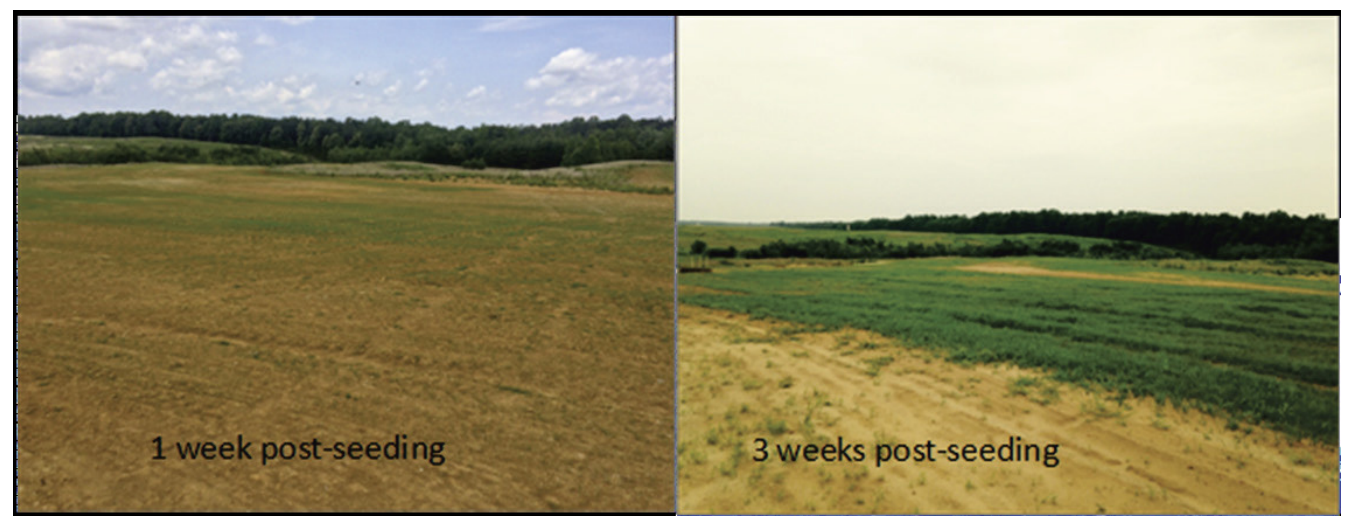


Sally A. Shoop. 2016. ERDC/CRREL TR-16-13. Image Analysis and Classification Based on Soil Strength, http://acwc.sdp.sirsi.net/client/en_US/search/asset/1050907

Satellite imagery classification is useful for a variety of commonly used applications, such as land use classification, agriculture, wetland delineation, forestry, geology, and landslide potential. However, image classification for physical properties of surface soils, such as strength or bearing capacity, is often obscured by other surface conditions, such as moisture and vegetation, although these are also indicators of soil strength. This project used remote methods of terrain analysis to search for areas suitable for vehicle or aircraft maneuverability based on slope, roughness, vegetation, soil type, and wetness and also performed direct classification of imagery based on soil strength. Using a maximum likelihood supervised classification approach, trained by a limited amount of ground-truth strength measurements, a soil strength classification was applied to WorldView-2 multispectral satellite imagery. This paper presents the work done on the imagery classification for soil strength, the apparent relationship between the reflectance and soil strength, and the ongoing work to expand the technique to new imagery by using existing training sets.

2013 WV2 image (left) and on-the-ground image (right) of the Tule landing zone.
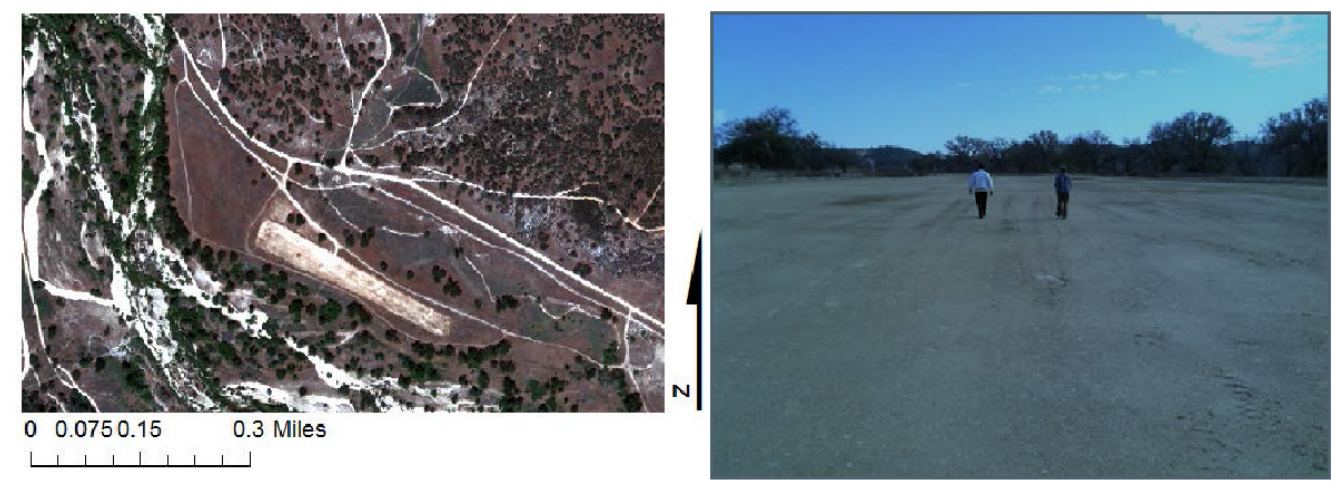

Ryan R. Busby. 2016. ERDC/CERL TR-16-9. Adaptation Strategies for Training Lands and Ranges at Fort Leonard Wood, MO, http://acwc.sdp.sirsinet/client/en_US/search/asset/1052188

In the United States and its territories, the Department of Army manages approximately 11 million acres of land for military use. The repeated and consumptive use of these lands for military training and testing activities, which is unique to $\mathrm{DoD}$, creates a significant land management challenge. Superimposed upon these types of disturbance-related impacts are climate change scenarios that predict warming and greater climatic variability for the foreseeable future, including more frequent and severe droughts and intense storm events. 
This work identified and described several key planning and management activities that can be implemented in the face of a changing climate to ensure that training and testing ranges at Fort Leonard Wood, MO will continue to provide sustainable, realistic, and cost effective training opportunities for the warfighter well into the future.
Native grasses, like Indian grass (Sorghastrum nutans), thrive with other grasses and forbs following prescribed burns.

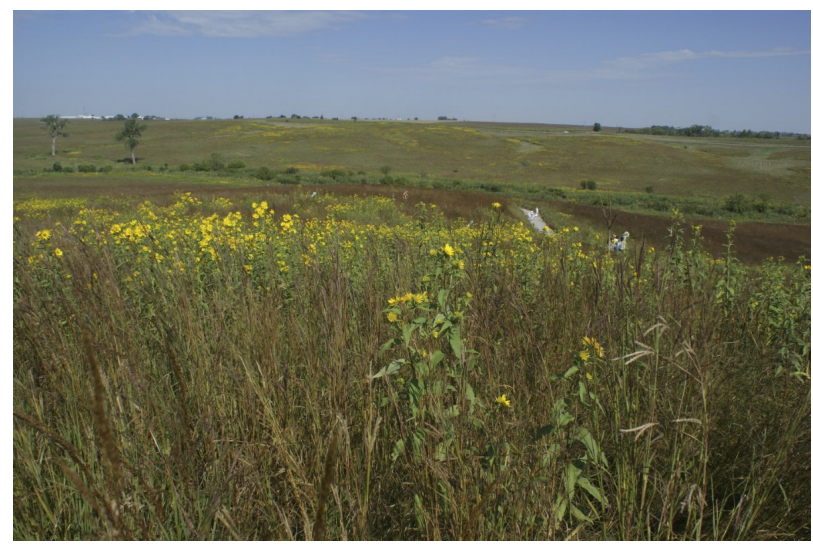

Lesley Miller. 2016. ERDC/EL SR-16-1. Nanomaterial Dispersion/Dissolution Characterization: Scientific Operating Procedure SOP-F-1, http://acwc.sdp.sirsinet/client/en_US/search/asset/1049986

Evidence suggests that a material's dispersion and dissolution behaviors may be crucial to understanding the material's environmental risk. Since exposure risks are directly determined by the environmental fate of nano silver (nAg), extensive efforts have been put forth in elucidating the behavior of these materials in natural systems. Thus, it is important to understand the different metrics that can be used to represent nanoparticles (NPs) in a system. Given the connection between a material's dispersion and dissolution kinetics, a protocol is presented to measure the dissolution kinetics of nanomaterials using a simple 48-hour experimental protocol that uses environmentally representative waters as well as non-destructive analytical techniques. Protocols for the simultaneous measurement of the nanoparticle dispersion properties are also presented. When used with the appropriate equations listed in this scientific operating procedure, data derived from these simple experiments can provide fundamental information about the behavior of nanoparticles in different environments. 
Kathy Keane. 2016. ERDC/EL CR-16-3. California Least Tern Foraging Ecology in Southern California: A Review of Foraging Behavior Relative to Proposed Dredging Locations, http://acwc.sdp.sirsi.net/client/en_US/search/asset/1049769

The California least tern (Sternula antillarum browni, hereafter CLT), one of three subspecies of the Least Tern, nests along the west coast of North America. Foraging occurs in bays, lagoons, estuaries, tidal marshes, river mouths, ponds and lakes, as well as in offshore deepwater habitats by plunge-diving for fish. Fifty species of prey fish have been identified as potential CLT prey. The CLT, listed as endangered by the Federal and California Endangered Species Acts, is afforded protection at its nesting sites in California. The relative importance of various forag-

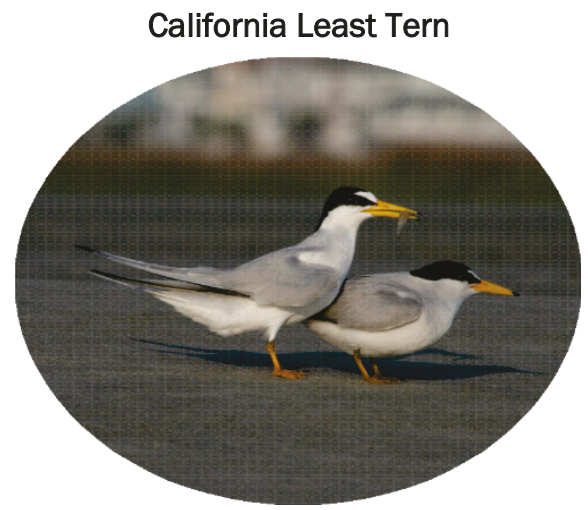
ing areas and foraging habitats near CLT nesting sites has not been evaluated, nor has official protection been designated to any CLT foraging areas, aside from seasonal limits on dredging sites recommended by the U.S. Fish and Wildlife Service (USFWS).

The U.S. Army Corps of Engineers (Corps) Los Angeles District conducts maintenance dredging along the California coast to ensure navigational access. Some of these sites are within foraging distance of CLT nesting areas. Dredging activities were generally limited to periods outside the CLT nesting season (April 15 to September 15) to avoid potential adverse effects on CLT foraging due to turbidity. This report summarizes the results of a literature review on studies and observations of CLT foraging and studies on the behavior of CLT forage fish in turbidity plumes. Results suggest that dredging activities may not substantially alter CLT foraging activity and seasonal restrictions on dredging near active CLT nesting sites provide no protections to this species and are not warranted. 
Jinelle Sperry. 2016. ERDC/CERL TR-16-3. Evaluation of 757 Species under U.S. Endangered Species Act Review on U.S. Department of Defense Lands and their Potential Impact on Army Training, https://erdclibrary.erdc.dren.mil/xmlui/bitstream/handle/11681/21101/ERDC-CERL\%20TR-163.pdf?sequence=1\&isAllowed =y

Most land bases where U.S. Army installations reside are ecologically significant and provide refuge for a large number of the Nation's threatened and endangered plants and animals. Balancing threatened and endangered species (TES) management with training requirements is an increasingly difficult responsibility as the number of federally listed species grows. This work developed methods for determining impacts of potential future TES listings to Army capabilities and conducted a national level assessment of the risk to Army training by species Sprague's pipit (Anthus spragueii) Source: USFWS (Doug Backlund, Wild Photos Photography॰) currently petitioned or under review

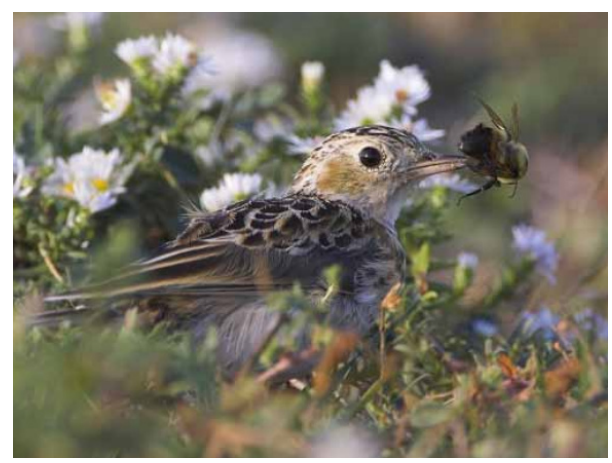
for Federal listing. Of the 757 species reviewed, 233 were found to have the potential to be found on or near Army and Army National Guard installations. Species that were found on a large number of installations, such as the Sprague's pipit (Anthus spragueii), are those likely to have the most impact on training. Similarly, installations at greatest risk were those that housed a large number of species. Because of the large number of southeastern U.S. petitioned species, the majority of installations identified as at greatest risk are installations found in that region. Proactive management of these species, including leveraging partner opportunities, has the potential to mitigate negative impacts of Endangered Species Act (ESA) listing.

David Delaney, Patrick Guertin, Michael White, et al. 2016. ERDC/CERL TN16-1. Assessment of Small Arms Munitions Impacts on Natural Infrastructure in Sensitive Downrange Areas on Military Installations, http://acwc.sdp.sirsi.net/client/en_US/search/asset/1048789

Large areas of high quality terrestrial natural infrastructure exist downrange of small arms training ranges on DoD installations. Live-fire training has caused concern to regulatory entities due to the potential impacts on natural resources, and to safety concerns expressed by adjoining land owners. This paper investigated whether there are reliable documented methods to quantify the number of bullets that escape the cantonment berm and end up down range via queries among Natural Resource peers and a technology 
review to document existing methods that address bullet fate on ranges. Responses to the inquiries indicate that Natural Resource personnel on military facilities or other state or Federal agencies do not have adequate tools or guidance to address the potential issue of smalls arms munition impacts within sensitive downrange areas. It was recommended that military installations further examine acoustical techniques for quantifying bullet overshot and ricochets into sensitive wildlife areas. Acoustical techniques offer a viable method for quantifying bullet intrusions into downrange areas. However, a more comprehensive testing procedure must be tested to gauge the effectiveness of this technique at bermed and unbermed ranges under different field conditions. 


\section{Green Remediation and Reuse}

In achieving its mission, the Corps must provide quality and responsive services in a manner that is environmentally, economically, and socially sustainable. The purpose of this focus area is to increase awareness and activity across USACE and the Army for incorporating sustainable practices into their environmental remediation and reuse activities.

Jonathon A. Brame. 2016. ERDC/EL SR-16-2. Composition of CBRN Decontamination Effluent and Development of Surrogate Mixtures for Testing Effluent Treatment Technologies, http://acwc.sdp.sirsinet/client/en_US/search/asset/1050948

Decontamination efforts after a chemical, biological, radiological, or nuclear (CBRN) event require large quantities of water and produce correspondingly large volumes of highly hazardous waste. This water use and production can be problematic in terms of logistics, safety, and liability during and after a domestic or military event. ERDC is developing a deployable effluent treatment sys-
Exercise in Vehicular Decontamination using the M26 mobile sprayer.

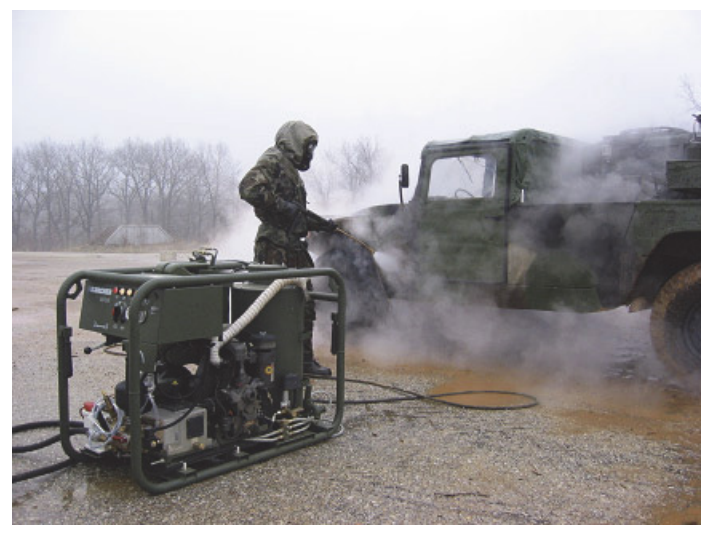
tem that could be used to treat the waste from decontamination operations for responsible discharge or potential reuse in decontamination activities. To develop such a system, it is important to understand and characterize the water that will be treated. Fortunately, there has been an absence of CBRN events to collect samples for analysis; so, the best alternative is to estimate the composition and concentration of components likely to be found in decontamination after such an event. This report summarizes our effort to provide that analysis, including the contribution of the CBRN agents, decontaminating agents, and additional materials produced as a result of washing (e.g., oil, dirt, hair, etc.). An estimate of the makeup and relevant concentrations of decontamination effluent is provided to enable testing of treatment technologies, which ensures complete removal of contaminants from decontamination effluent. 
Donna J. Schell. ERDC/CERL SR-16-2. Removing Hazardous Materials from Buildings: $A$ Training Curriculum.

There has been little or no formalized training available within the Army for installation personnel to appropriately identify, handle, and dispose of hazardous materials generated during the renovation and/or demolition of Army buildings. As the Army's new construction programs wind down, attention must be paid to operation, repair, and renovation of existing facilities-where hazardous materials are more likely to be encountered. An ad hoc, reactive approach to dealing with hazardous materials will adversely impact repair, renovation, and operation budgets and schedules while increasing the likelihood of regulatory noncompliance. Development of a training regimen was previously deferred but is now being addressed. Per direction from the Office of the Assistant Chief of Staff for Installation Management Facility Policy Division (DAIM-ODF), a Public Works Technical Bulletin, "Toxics Management," was completed in 2014 and published through Headquarters, U.S. Army Corps of Engineers. That publication provides guidance to address specific toxic and hazardous materials associated with buildings that are owned, leased, or otherwise controlled by the Department of the Army. For additional training documentation, this report captures a workshop-style training curriculum developed to enable installation operations and management personnel to identify, handle, and dispose of hazardous building materials in a safe, thorough, efficient, compliant, and economical manner.

\section{Zhonglong Zhang. 2016. ERDC/EL TR-16-11. Testing and Validation Studies of the NSMII-Benthic Sediment Diagenesis Module, http://acwc.sdp.sirsinet/client/en_US/search/asset/1050526}

Nutrient Simulation Modules (NSMs) have been developed as "plug in" water quality modules for HEC-RAS and other hydrologic and hydraulic models. The NSMs model multiple water quality constituents and biogeochemical processes in the water column. The NSMs consist of two modules: NSMI and NSMII, differing mainly in the number of water quality constituents (state variables) and kinetic processes (transformations) included. The benthic sediment diagenesis module was developed as an option module for coupling with the NSMI and NSMII water column kinetics. Sediment-water fluxes of dissolved oxygen and nutrients are computed internally rather than prescribed if the benthic sediment diagenesis module is activated. The ability of the NSMII-benthic sediment diagenesis module to correctly predict sediment-water nutrient fluxes and sediment 
oxygen demand was validated and evaluated against observed data and existing benthic sediment diagenesis models through a series of case studies. These case studies were chosen for representing various sedimentation and environmental conditions in aquatic systems. The simulated sediment-water nutrient fluxes and sediment oxygen demand over time were generally in good agreement with observed data and two model results for all test cases. This report documents testing and evaluation of the NSMIIbenthic sediment diagenesis module. The report describes the testing conditions, model inputs, and model results.

\section{Zhonglong Zhang. 2016. ERDC/EL TR-16-8. Aquatic Contaminant and Mercury Simulation Modules Developed for Hydrologic and Hydraulic Models, http://acwc.sdp.sirsinet//client/en_US/search/asset/1050727}

This report offers details regarding the theory and mathematical formulations implemented in the newly developed general constituent (GC) simulation module, contaminant simulation module (CSM), and mercury simulation module (HgSM). The GC models simple kinetics for multiple size classes of solids and user-defined constituents in the water column. The CSM models the kinetics of user-defined contaminants in aquatic systems. The kinetic processes modeled in CSM include: ionization, multi-phase partitioning, degradation, photolysis, hydrolysis, volatilization, generalized second-order reaction, and transformations where one chemical species undergoes a reaction and is transformed to a daughter product. The HgSM models mercury species (elemental mercury, inorganic mercury, and methylmercury) and their cycling in aquatic systems. The three water quality modules only compute internal sources and sinks of each state variable for both water column and an underlying sediment layer. The GC, CSM and HgSM modules are written as "plug in" dynamic link libraries and compiled as GC.dll, CSM.dll and HgSM.dll respectively. These modules have been integrated into the HEC-RAS model and will also be integrated into other hydrologic and hydraulic models (e.g., AdH [Adaptive Hydraulics] and SRH-2D).

\section{Steven Larson. 2016. ERDC TR-16-5. Evaluation of Rhizobium tropici-derived Biopolymer for Erosion Control of Protective Berms. Field Study: Iowa Army Ammunition Plant, http://acwc.sdp.sirsi.net/client/en_US/search/asset/1050309}

A Rhizobium tropici produced biopolymer was applied to an explosion protection berm at the Iowa Army Ammunition Plant (IAAAP) to stabilize the soil, prevent loss of berm height, reduce erosion, and increase the rate and extent of revegetation. The berm was recontoured, and a hydroseeder 
was used to apply biopolymer with grass seed. The control area received plain water and seed. Evaluated biopolymer application methods include single surface application, double surface application, and a double application at depth, with the first application 2-ft below ground surface (bgs), and the second on the surface.

\section{A Light Detection and Ranging} (LiDAR) survey evaluated soil movement from the berm slope over 3 years. The double application of the biopolymer at depth was the most effective application method, as determined by calculating soil loss and surface roughness, followed closely by the double surface application. At 19 months post-treatment, a landslip was observed in the treated area that received the double surface application of the biopolymer. There was no evidence of soil cracking in any of the other treated areas. The slip appears to be due to an indentation in the crest of the berm that channeled runoff water into the area of the slip. Slope stabilization using biopolymer is approximately half the cost of construction and maintenance of traditional earthen berms over a $30-$ year period, due to lower installation and maintenance costs.

\section{Steve L. Larson. 2016. ERDC/EL TR-16-7. Flexible Reactive Berm (FRBerm) for Removal of Heavy Metals from Runoff Water: ER-1213 Treatability Study, http://acwc.sdp.sirsinet/client/en_US/search/asset/1050308}

SAFRs located on DoD facilities are, in many cases, constructed next to wetland areas. These wetlands represent a potential point of regulatory interest as they are at risk from heavy metal contamination. Access to wetland areas is typically limited due to a lack of roads. Standard environmental remedial options and monitoring
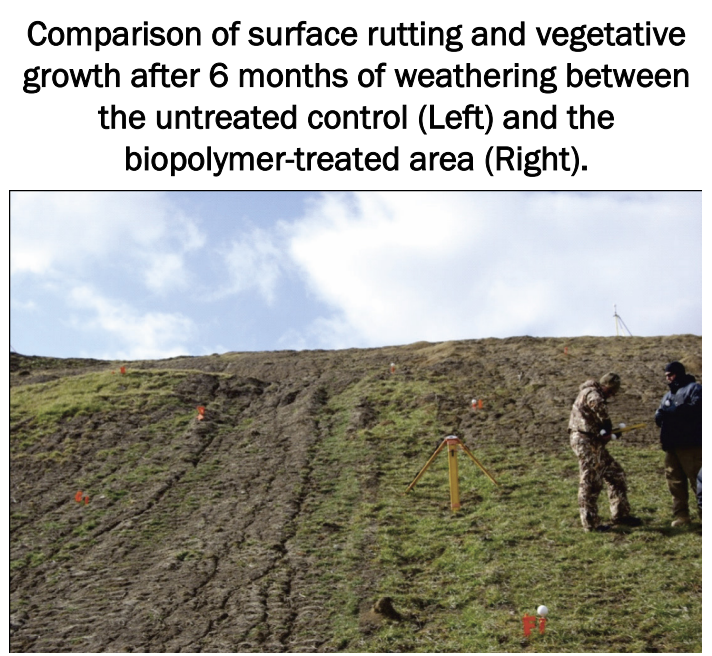
techniques are expensive to implement due to the nature of the terrain and seasonal changes in water flow. Metals are highly associated with the soil particles making up the total suspended solids (TSS) in the runoff water. Reactive materials were assembled into a barrier similar to erosion control socks. Socks were constructed using a nonwoven geotextile filled with well-graded sand, amended with $5 \%$ weight: weight, w:w) iron/manganese-oxides (TRAPPS ${ }^{\mathrm{TM}}$ ) and/or $5 \%(\mathrm{w}: \mathrm{w})$ treated apatite. The socks were tested under mesoscale lysimeter conditions and removal of metals from solution was confirmed. The reactive socks adsorbed greater than $95 \%$ of metals in the solution. Once the reactive material was exhausted, it was tested and found to pass the Toxicity Characteristic Leaching Procedure (TCLP) test for placement in a non-hazardous waste landfill. Positioning of the socks in the pathway of runoff water for the field demonstration was determined using predictive models for surface runoff.

Jay Clausen. 2016. ERDC TR-16-4. Impact of Incremental Sampling Methodology (ISM) on Metals Bioavailability, http://acwc.sdp.sirsi.net/client/en_US/search/asset/1049686

This study assessed the impact of the ISM on metals bioavailability through a series of digestion and in vivo experiments. These tests used Eisenia fetida and Lolium rigidum in both milled and unmilled loam and sand soil containing antimony, copper, lead, and zinc obtained from Donnelly Training Area, AK. No significant differences in metal levels were evident between milled and unmilled soil for E. fetida, and uptake of lead by $L$. rigidum in sand yielded lead recoveries comparable with Method 3050 analysis of soil. In contrast, L. rigidum grown in loam had

Earthworms used in the study.

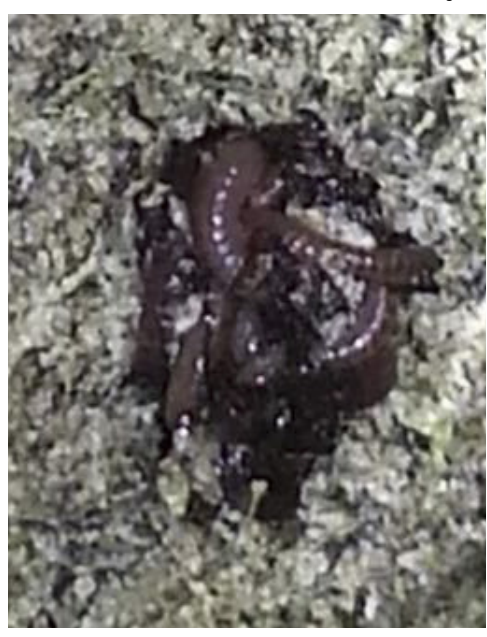
much lower recoverable lead. Milling of the soil as part of the ISM process had no significant impact on the lead species distribution. In comparison with Method 3050, the alternative digestion tests involving the use of glycine; oxalate; ethylenediaminetetraacetic acid (EDTA); or alternative digestion procedures, such as the synthetic precipitation leaching procedure (SPLP) and the TCLP, yielded lower recoveries of lead for all soil particle sizes and soil types. Diffusive gradient in thin films experiments yielded metal concentrations positively correlated with $E$. fetida concentrations. 
The physiologically based extraction technique (PBET) positively correlated with bulk soil concentrations and E. fetida tissue concentrations for all soils evaluated.

Jay L. Clausen. 2016. ERDC/CRREL TR-16-10. Passive Gamma-Ray Emission for Soil-Disturbance Detection, http://acwc.sdp.sirsinet/client/en_US/search/asset/1050706

Human-terrain interactions, such as trafficking and excavation, cause changes to soil bulk density and porosity via compaction or mechanical bulking. The degree of compaction, as measured by bulk density, is a physical indicator of changing patterns of human-terrain interaction. Because soil radionuclide activity is a function of the mass content of the radionuclide and the volume of soil,

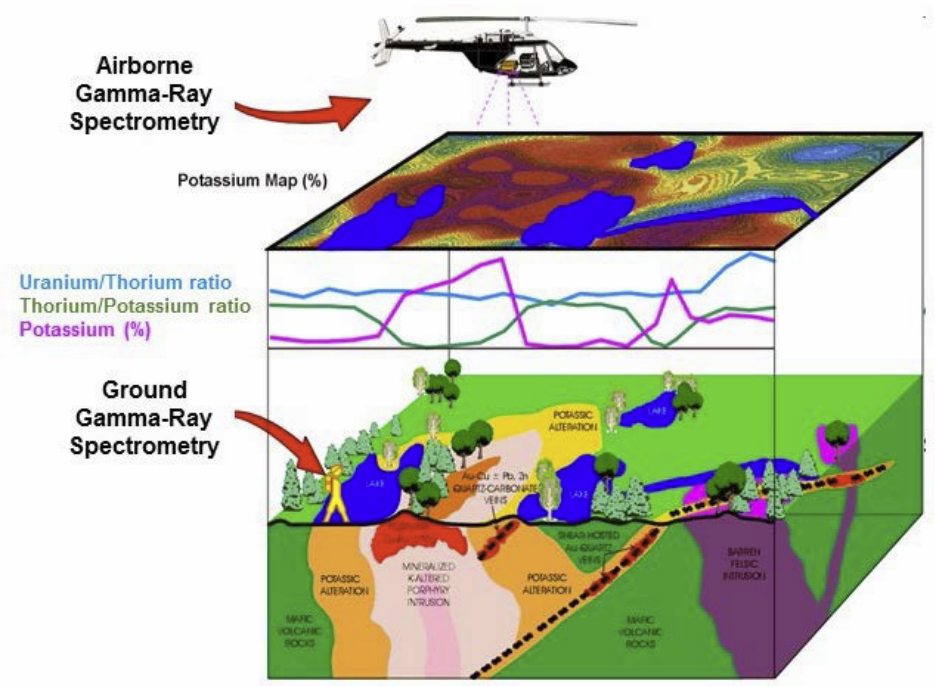
the spectral signature of the naturally occurring soil radioisotope Potassium-40 (40K) should be sensitive to changes in the soil bulk density and reflect the soil's disturbance history. If natural variations from geology and soil texture are systematic and predictable, one could map spatiotemporal bulk density changes relative to some standard state as a metric of terrain disturbance. However, the natural variation in soil $40 \mathrm{~K}$ content is unknown and may confound density determinations via radionuclide activity measurements. This study used a handheld sodium iodide gamma-ray detector to collect in situ gamma-ray spectra of four soils as a function of their potassium content, bulk density, texture, and water content. A statistically significant difference between the $40 \mathrm{~K}$ activity of uncompacted and compacted soil suggests that in situ $40 \mathrm{~K}$ gamma-ray emissions from soils are a sensor modality useful for soil-disturbance detection. 
Michael R. Walsh. 2016. ERDC/CRREL MP-16-2. A Portable Burn Pan for the Disposal of Gun Propellants, http://acwc.sdp.sirsi.net/client/en_us/search/asset/1052146

Munitions for indirect fire weapon systems are issued with a full complement of propellant charges. Excess charges are typically not turned in and are destroyed by open burning as part of the unit's training. Burning of the charges can result in up to $20 \%$ of the propellant remaining in the form of residues on the ground. A portable propellant burn pan system was design and demonstrated as part of ESTCP Project ER-201323 to enable safe, environmentally effective training of the military. Tests have demonstrated a $99.98 \%$ reducPrototype burn pan.

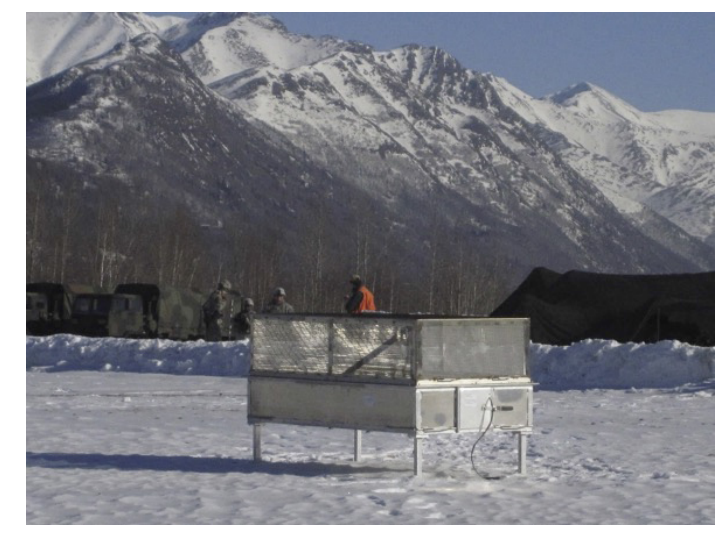
tion in combustible mass of the charges, less than $0.001 \%$ of the energetics in the burn pan ash, energetics concentration of less than $0.5 \%$ in the residual ash, and no detectable difference in energetics in the soil surrounding the pan after burning over $450 \mathrm{~kg}$ of charges. Performance objectives for the burn pan device were met or exceeded by the final system design. Costs associated with acquisition, implementation, use, and maintenance of the burn pan system are reasonable. The CRREL portable propellant burn pan training device has been enthusiastically accepted by all who have participated in the ER-210323 test and demonstration program.

\section{Jason C. Weale. 2016. ERDC/CRREL TR-16-15. Aviation Fuel Ignition and Burn Behavior in Antarctica, http://acwc.sdp.sirsi.net/client/en_US/search/asset/1051386}

The U.S. Antarctic Program (USAP) currently employs a combination of DoD and Federal Aviation Administration Airfield Rescue Fire Fighting (ARFF) standards that were developed for traditional airfield environments with runways and associated facilities constructed on soil and pavements. These requirements originated from results obtained during fuelspill-triggered pool fires and their resulting extinguishing needs. There are no known standards describing the combustion behavior at Antarctic temperatures of AN-8, JP-8 (“Jet propellant 8," a kerosene-based fuel), Jet-A, or other aircraft fuels spilled on airfields built on sea ice, glacial ice, and deep snow. Laboratory-scale samples of these airfield surfaces were constructed; and increasing volumes of Jet-A fuel was spilled on each at decreasing temperatures, and fuel ignition was immediately attempted. We 
determined that in a controlled laboratory environment, Antarctic airfield materials and the cold environment significantly influence the ignition and combustion characteristics of Jet-A by combining to create a situation where the aviation pool fire typical in temperate environments is highly unlikely. Modifications to the existing USAP ARFF response criteria, procedures, and resources required to meet the actual risks should be investigated. We also recommend changing the Antarctic ARFF tactics to (1) first get the people out of the aircraft and then (2) deal with the fire because the primary risk following an incident is likely to be hypothermia rather than fire-induced injuries.

\section{Linda Nelson. 2016. ERDC/EL CR-16-5. Complete Host Range Testing on Common Reed with Potential Biological Control Agents and Investigation into Biological Control for Flowering Rush, http://acwc.sdp.sirsinet/client/en_US/search/asset/1050686}

The noctuid moths, Archanara geminipuncta and A. neurica, were selected as the most promising candidates for biological control of common reed. Successful larval development was only found on Phragmites spp., but development was also possible on the native North American subspecies $P$. australis subsp. americanus. However, open-field oviposition tests showed a strong preference of females for both European and introduced P. australis. Because of the higher egg mortality on native reed, the authors expect any impact of $A$. neurica and A. geminipuncta on the native reed $P$. australis subsp. americanus to be negligible, should the noctuids be released in North America. A biological control project for flowering rush was

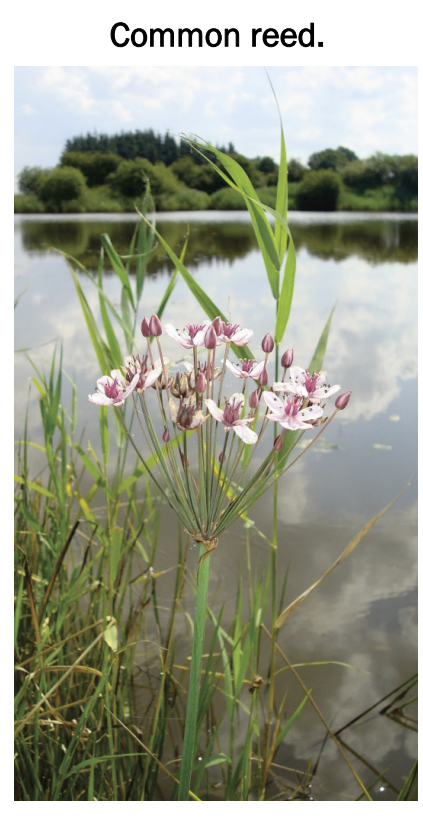
started in spring 2013. According to the authors' literature survey, the semiaquatic weevil, Bagous nodulosus, is the most promising potential agent for biological control. During various field surveys in Northern Germany, the Czech and Slovak Republics, Hungary, Poland, and Serbia, the authors collected several hundred adults of B. nodulosus, established a rearing colony, and started with sequential no-choice oviposition tests. So far, no eggs were found on any of the 22 test plants offered. The authors also found the other five herbivore species recorded as monophagous on flowering rush and started work with a second weevil, B. validus. 
John M. Nestler. 2016. ERDC/EL CR-16-4. Side Channels of the Impounded and Middle Mississippi River: Opportunities and Challenges to Maximize Restoration Potential, http://acwc.sdp.sirsi.net/client/en_US/search/asset/1050690

A 2.5-day interagency workshop attended by river scientists and engineers was held in Cape Girardeau, MO, from 10-12 January 2011. The goal of the workshop was to develop conceptual models (CMs) to guide side channel restoration planning for the Middle Mississippi River. Side channels support a wide range of ecological processes, functions, and biota in large river systems like the Middle Mississippi. CMs are needed to link the physical, chemical, climatic, and human factors shaping side channel habitat dynamics to help restoration planners select an optimum restoration strategy. The workshop attendees were organized into three breakout groups (each with a facilitator and recorder) that were tasked with developing their own CM describing ecological dynamics of side channels. The breakout groups met in plenary sessions to receive instructions, share progress, and to draw final conclusions at the end of the workshop. Each breakout group developed unique, but complementary, CMs that represented one perspective of the complex, multidimensional environmental and institutional reality of side channels restoration. It is concluded that CMs (like population models) cannot simultaneously maximize generality, realism, and accuracy; only two of these functions can be maximized at the expense of the third. As with all $\mathrm{CMs}$, these are works-in-progress that represent the current state of understanding and practice for this ecosystem as perceived by the individual experience, training and creativity of the workshop attendees.

\section{Billy E. Johnson. 2016. ERDC/EL TN-16-1. CONUS Demonstration Site Selection for Surface Water Characterization in Remote, Sparse-Data Environments: Calleguas Creek Watershed, Ventura County, California, http://acwc.sdp.sirsi.net/client/en_US/search/asset/1049467}

The purpose of this Environmental Qualities Technology (EQT) technical note is to document the site selection criteria, available data present, and site characterization in the Calleguas Creek Watershed, Ventura County, CA for the purpose of demonstrating and validating the models being developed under the EQT Focus Area entitled "Surface Water Characterization in Remote Sparse Data Environments.” This work unit will be developing a landscape-scale model capable of simulating flow, sediment, and contaminants across large spatial and temporal scales. The output from this system will be used to develop boundary conditions for the HEC-RAS to model detailed 1-D and 2-D channel sedimentation and contaminant fate and transport. The CONUS demonstration study will not only validate 
the process descriptions found within the modeling systems but will also be used to test and debug the Surrogate Watershed Approach to model parameter estimation and the Source Zone Loading toolkit being developed within the focus area.

Victor F. Medina. 2016. ERDC/EL TR-16-3. Testing of the KRIA lonizing Water Treatment System for Waters Contaminated with Diesel, PCBs, and Nutrients (Nitrogen Forms), http://acwc.sdp.sirsi.net/client/search/asset/1048390

This project evaluated the KRIA water treatment system (also known under the trade name ECOSOAR) for treatment of three environmental contaminants: diesel fuel, Polychlorinated Biphenyls (PCBs) (arochlor 1254) and nutrients (nitrogen forms). The KRIA water treatment system works by charging water with the superoxide radical (O2-), which is electrochemically generated from oxygen in the atmosphere. At the injection site, both cavitation and microbubble reactions may also occur. A review of the literature indicates that superoxide is a relatively weak radical, but it can work both oxidatively and reductively. A review of the literature also showed that superoxide can transform chlorinated solvents

Field deployment of the KRIA water treatment system.

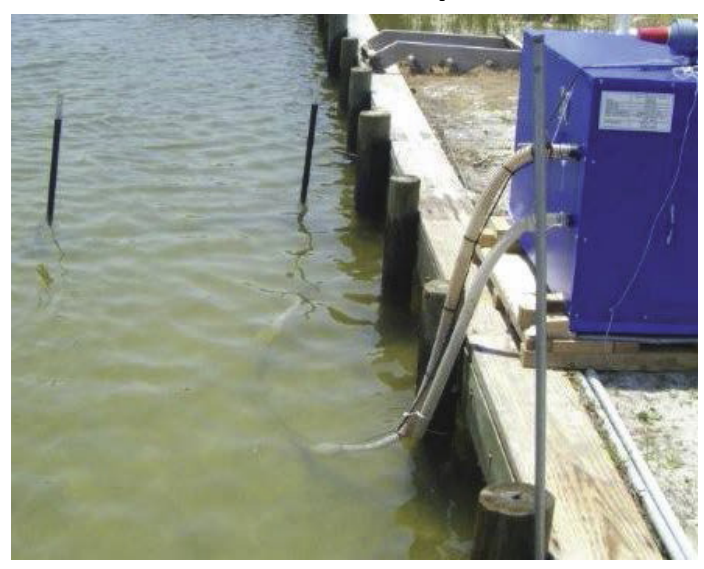
and microcystin (a toxin associated with algae). Studies of the KRIA yielded promising results, but most of these studies lacked sufficient control to isolate variables, possibly casting doubt on the exact nature of the mechanism. Background studies were conducted to evaluate the KRIA's effect on water. The KRIA charged water for 135 minutes and was compared to a control in which the superoxide valve was turned off. It was found that the superoxide charging resulted in elevated (approximately threefold) levels of oxygen, which led to the water being supersaturated (by approximately $300 \%$ ). Conductivity was also increased, presumably due to the addition of charged oxygen species into the water. These elevated levels persisted for at least 24 hours after the charging, suggesting that the effect was persistent. The team also documented elevated concentrations of superoxide ion after charging. Treatment of diesel resulted in a $58 \%$ increase in removal compared to the control reactor, and this was statistically sig- 
nificant. Treatment of PCBs resulted in a $20 \%$ increase in removal as compared to the control, and was also statistically significant. Treatment of nutrients (ammonia and nitrate) did not appear to result in any changes to their respective concentrations.

Richard A. Cole. 2016. ERDC/EL TR-16-5. The Biodiversity Security Index: $A$ New Metric for Benefits from USACE Ecosystem Restoration Projects, http://acwc.sdp.sirsi.net/client/search/asset/1049469

This technical report summarizes progress made in the development of the Biodiversity Security Index (BSI), a new nonmonetary metric designed for use by USACE to indicate the environmental benefit from ecosystem restoration projects planned and implemented by USACE. The BSI was designed to compare ecosystem restoration benefits across plans during project planning and across projects during annual ranking of projects for budget recommendations. It may also be used to compare monitored actual project performance with planned performance. The information presented herein is a synthesis of unpublished research and the results of previously published and draft technical reports. This publication describes the need for a new metric; the main metric elements; how the main metric elements are calculated and assembled into a metric unit; and the advantages the BSI offers in comparison to other metrics. It is not intended to serve as an implementation manual (which is under separate development). The intended audience is USACE planners and collaborators and others who are generally familiar with the USACE six-step planning process.

Victor F. Medina. 2016. ERDC/EL TR-16-10. Laboratory-Scale Demonstration Using Dilute Ammonia Gas Induction of Alkaline Hydrolysis Treatment of Soil Chlorinated Propanes and Explosives, http://acwc.sdp.sirsinet/client/en_US/search/asset/1050487

Many environmental contaminants are amenable to degradation by alkaline hydrolysis. This project explored the use of ammonia gas to raise soil $\mathrm{pH}$ to stimulate alkaline hydrolysis. When ammonia gas dissolves in water, it forms ammonium ion, which consumes hydrogen ions
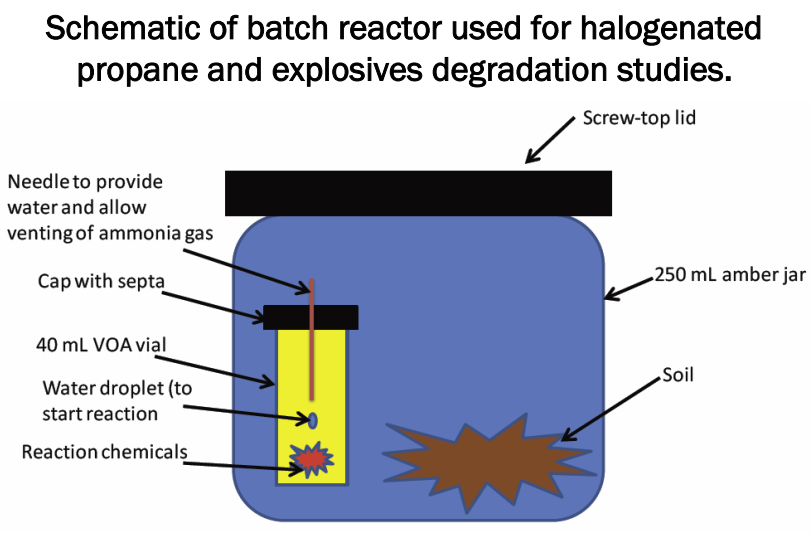
$(\mathrm{H}+)$, thereby increasing $\mathrm{pH}$. This study established that $5 \%$ ammonia in air can increase soil $\mathrm{pH}$ from 7.5 to 10.3. Batch studies indicate that this $\mathrm{pH}$ increase can stimulate alkaline hydrolysis reactions, resulting in the degradation of chlorinated propanes (trichloropropane, dichloropropane) and explosives (2,4,6-trinitrotoluene, nitrobenzene, and cyclotrimethylene-trinitramine [RDX]). A column study was conducted focusing on evaluating the penetration of ammonia and subsequent $\mathrm{pH}$ change. The study showed $\mathrm{pH}$ penetration of $20 \mathrm{~cm}$ in a $2.5 \mathrm{~cm}$ diameter column over 7 days, with a flow of $5 \%$ ammonia gas at $1 \mathrm{sccm}$ (standard cubic centimeter per minute). Chlorinated propane concentrations were reduced from levels of as high as $2400 \mu \mathrm{g} / \mathrm{kg}$ to as low as non-detect. A small amount of these were captured in the column off gas. The team also explored whether ammonia gas exposure could stimulate metabolic activity of ammonia-oxidizing microorganisms. A 283-day experiment did not result in any measureable increase in ammonia-oxidizing microorganisms, but the team found significant increases in soil nitrogen concentrations. 


\section{Acronyms and Abbreviations}

\begin{tabular}{|c|c|}
\hline Term & Definition \\
\hline ACE & Anaerobic-Clinoptilolite-Electrolysis \\
\hline AdH & Adaptive Hydraulics \\
\hline AFB & Air Force Base \\
\hline AHF & Anharmonic Folds \\
\hline ANSI & American National Standards Institute \\
\hline ARFF & Airfield Rescue Fire Fighting \\
\hline BCSD-CMIP5 & $\begin{array}{l}\text { Bias-Corrected Statistical Downscaling-Coupled Model Intercomparison } \\
\text { Project Phase } 5\end{array}$ \\
\hline $\mathrm{BDI}$ & Bridge Diagnostics, Inc. \\
\hline BEAR & Basic Expeditionary Airfield Resources \\
\hline BMP & Best Management Practice \\
\hline $\mathrm{BOB}$ & BEAR Order of Battle \\
\hline BRAC & Base Realignment and Closure \\
\hline BSI & British Standards Institute \\
\hline $\mathrm{CA}$ & Capability Approach \\
\hline CAD & Computer-Aided Design \\
\hline CASI & Center for the Advancement of Sustainability Innovations \\
\hline CAWS & Chicago Area Waterway System \\
\hline $\mathrm{CB}$ & Contingency Base \\
\hline CBRN & Chemical, Biological, Radiological, and Nuclear \\
\hline CCAFS & Cape Canaveral Air Force Station \\
\hline CERL & Construction Engineering Research Laboratory \\
\hline CFD & Computational Fluid Dynamics \\
\hline CLT & California Least Tern \\
\hline $\mathrm{CM}$ & Conceptual Models \\
\hline CONUS & Continental United States \\
\hline CR & Contract Report \\
\hline CRISPR & Clustered Regularly Interspaced Short Palindromic Repeat \\
\hline CRREL & Cold Regions Research and Engineering Laboratory \\
\hline CSM & Contaminant Simulation Module \\
\hline CTS & Chemical Transformation Simulator \\
\hline CVWF & Central Vehicle Wash Facility \\
\hline DAIM-ODF & $\begin{array}{l}\text { Office of the Assistant Chief of Staff for Installation Management } \\
\text { Facility Policy Division }\end{array}$ \\
\hline DHS & U.S. Department of Homeland Security \\
\hline DNA & deoxyribonucleic acid \\
\hline DoD & U.S. Department of Defense \\
\hline DPW & Directorate of Public Works \\
\hline ECALS & Asian Carp eDNA Calibration Study \\
\hline
\end{tabular}




\begin{tabular}{|c|c|}
\hline $\begin{array}{l}\text { Term } \\
\text { ECMI }\end{array}$ & $\begin{array}{l}\text { Definition } \\
\text { Ecological Characterization and Monitoring Initiative }\end{array}$ \\
\hline ECU & Environmental Control Unit \\
\hline eDNA & environmental DNA \\
\hline EDTA & Ethylenediaminetetraacetic Acid \\
\hline EIS & Environmental Impact Statement \\
\hline EKO & Engineering Knowledge Online ${ }^{\mathrm{TM}}$ \\
\hline EL & Environmental Laboratory \\
\hline EMI & Electromagnetic Induction \\
\hline EN & Electroless Nickel \\
\hline EPS & Extracellular Polymeric Substance \\
\hline EQT & Environmental Quality Technology \\
\hline ER & Environmental Restoration \\
\hline ERDC & U.S. Army Engineer Research and Development Center \\
\hline ERDC-CERL & $\begin{array}{l}\text { Engineer Research and Development Center, Construction Engineering } \\
\text { Research Laboratory }\end{array}$ \\
\hline ERDC-CRREL & $\begin{array}{l}\text { Engineer Research and Development Center, Cold Regions Research } \\
\text { and Engineering Laboratory }\end{array}$ \\
\hline ERDC-EL & Engineer Research and Development Center, Environmental Laboratory \\
\hline ES2 & Energy Security and Sustainability \\
\hline ESA & U.S. Endangered Species Act \\
\hline ESTCP & Environmental Security Technology Certification Program \\
\hline FLV & Floating Leaf Vegetation \\
\hline FOB & Forward Operating Base \\
\hline FOUO & For Official Use Only \\
\hline FQI & Floristic Quality Index \\
\hline FRP & Fiber-Reinforced Polymer \\
\hline FY & Fiscal Year \\
\hline GC & General Constituent \\
\hline GCM & Global Circulation Model \\
\hline GFRP & Glass Fiber-Reinforced Polymer \\
\hline GHG & Greenhouse Gas \\
\hline GIS & Geographic Information System \\
\hline GLRI & Great Lakes Restoration Initiative \\
\hline GPR & Ground-Penetrating Radar \\
\hline GrIT & Greenland Inland Traverse \\
\hline HAB & Harmful Algal Bloom \\
\hline HAER & Historic American Engineering Record \\
\hline HCB & Hybrid-Composite Beam \\
\hline HDS & Heat-Distribution System \\
\hline HEC-RAS & Hydrologic Engineering Centers River Analysis System \\
\hline HF & Harmonic Fold \\
\hline $\mathrm{Hg}$ & Mercury \\
\hline
\end{tabular}




\begin{tabular}{|c|c|}
\hline $\begin{array}{l}\text { Term } \\
\text { HGM }\end{array}$ & $\begin{array}{l}\text { Definition } \\
\text { Hydrogeomorphic }\end{array}$ \\
\hline $\mathrm{HgSM}$ & Mercury Simulation Module \\
\hline HISA & Human-Infrastructure System Assessment \\
\hline HVAC & Heating, Ventilating, and Air-Conditioning \\
\hline IAAAP & lowa Army Ammunition Plant \\
\hline ISM & Incremental Sampling Methodology \\
\hline ITAM & Integrated Training Area Management \\
\hline JBLE-E & Joint Base Langley-Eustis \\
\hline JFTC & Joint Forces Training Center \\
\hline JOA & Joint Area of Operations \\
\hline LID & Low Impact Development \\
\hline LiDAR & Light Detection and Ranging \\
\hline ManPlan & management plan \\
\hline $\mathrm{MC}$ & Munitions Constituents \\
\hline MCB & Marine Corps Base [Camp] \\
\hline MICC & Microbially Induced Concrete Corrosion \\
\hline $\mathrm{MJH}$ & Matthew Jones House \\
\hline MOA & Memorandum of Agreement \\
\hline MOU & Memorandum of Understanding \\
\hline MP & Miscellaneous Publication \\
\hline MRRP & Missouri River Recovery Program \\
\hline NCPTT & National Center for Preservation Technology and Training \\
\hline NHPA & National Historic Preservation Act of 1966 \\
\hline NP & Nanoparticle \\
\hline NRHP & National Register of Historic Places \\
\hline NSM & Nutrient Simulation Module \\
\hline NSN & National Supply Number \\
\hline NZE & Net Zero Energy \\
\hline NZW & Net-Zero Water \\
\hline $\mathrm{OE}$ & Operational Energy \\
\hline OHWM & Ordinary High Water Mark \\
\hline OMB & Office of Management and Budget \\
\hline ORAP & [U.S. Army] Operational Range Assessment Program \\
\hline OSAF & Optimal Stationing of Army Forces \\
\hline PAL & Protective Action Limit \\
\hline PBET & Physiologically Based Extraction Technique \\
\hline PCB & Polychlorinated Biphenyl \\
\hline PMESII-PT & $\begin{array}{l}\text { Political, Military, Economic, Information, Infrastructure, Physical } \\
\text { environment, and Time }\end{array}$ \\
\hline $\mathrm{POC}$ & Point of Contact \\
\hline RCP & Representative Concentration Pathway \\
\hline
\end{tabular}




\begin{tabular}{ll} 
Term & Definition \\
RDX & hexahydro-1,3,5-trinitro-1,3,5-triazine \\
RNA & ribonucleic acid \\
ROI & Return on Investment \\
RTU & Remote Transmitting Unit \\
RU-MSO & Remedy Ultra and Methylated Seed Oil \\
SAFR & Small Arms Firing Range \\
SAR & Species at Risk \\
SAV & Submerged Aquatic Vegetation \\
SCADA & Supervisory Control And Data Acquisition \\
SDD & Sustainable Design and Development \\
SEEDS & Smart Energy Efficient Deployable Shelters \\
SERDP & Strategic Environmental Research and Development Program \\
SF & Standard Form \\
SMART & Specific, Measurable, Attainable, Realistic, and Timely \\
SOP & Scientific Operating Procedure \\
SPLP & Synthetic Precipitation Leaching Procedure \\
SR & Special Report \\
TCLP & Toxicity Characteristic Leaching Procedure \\
TEAM & The Environmental Assessment Management \\
TES & Threatened and Endangered Species \\
TN & Technical Note \\
TNC & The Nature Conservancy \\
TNT & 2,4,6-trinitrotoluene \\
TR & Technical Report \\
TREECS & Training Range Environmental Evaluation and Characterization System \\
TSS & Total Suspended Solids \\
USACE & U.S. Army Corps of Engineers \\
USAP & U.S. Antarctic Program \\
USEPA & U.S. Environmental Protection Agency \\
USFWS & U.S. Fish and Wildlife Service \\
USGBC & US Green Building Council \\
UWMM & Underwater Military Munitions \\
VESCA & Violent Events Sociocultural Analysis \\
WASP & WAter Stress Projection \\
WWTP & Wastewater Treatment Plant \\
& \\
\hline &
\end{tabular}




\title{
12 Included Documents
}

\author{
Focus Area / Document Page
}

Anticipating Emerging Issues

Material Life Cycle Analysis for the Reduction of Waste Generation at Military Installations 10 Identification of Insect-Plant Pollination Networks for a Midwest Installation: Fort McCoy, WI 10 Invasive Species Management on Military Lands: Clustered Regularly Interspaced Short Palindromic Repeat/CRISPR-associated protein 9 (CRISPR/Cas9)-based Gene Drives 11 Extreme Environment Basing: Contingency Basing in Dense Urban and Megacity Environments

Assessment of Small Arms Munitions Impacts on Natural Infrastructure in Sensitive Downrange Areas on Military Installations

\section{Climate-Driven Risks to Natural and Built Environments}

Evaluation of Methods for Assessing Vulnerability of Army Installations to Impacts of Climate Change on Listed and At-Risk Species

Climate Change Vulnerability of Army Installations Attributable to Listed and At-Risk Species Multiscale Assessment of Listed and At-Risk Species' Climate Change Vulnerabilities

Use of Heating and Cooling Degree Days to Project Relative Changes in Heating and Cooling Costs In Response to Climate Change on Selected Army Installation

Effects of Climate Change and Urban Development on Army Training Capabilities: Firing Ranges and Maneuver Areas

Effects of Climate Change, Urban Development, and Threatened and Endangered Species Management on Army Training Capabilities: Firing Ranges

Water Stress Projection Modelin

Use of Heat- and Fire-Risk Indices to Project Local Climate Impacts on Selected Army Installations

Effects of Climate Change and Urban Development on Army Training Capabilities: Firing Ranges and Maneuver Areas

Effects of Climate Change, Urban Development, and Threatened and Endangered Species Management on Army Training Capabilitie

Black-Swan Event Assessment for Fort Leonard Wood, Missouri

Sustainable Installations - Net-Zero Planning

Fort Leonard Wood Net Zero Water Program: Project Documentation for Fiscal Year 2015

\section{Sustainable Energy Solutions}

Demonstration of a Robust Sensor System for Remote Condition Monitoring of HeatDistribution System Manholes: Final report on Project F09-AR03

Characterization of the Lake Erie Ice Cover

Economic Analysis of the Greenland Inland Traverse (GrIT)

\section{Sustainable Water \& Waste Resources}

Methylmercury Screening Models for Surface Water Habitat Restoration: A Case Study in Duluth-Superior Harbor

Operational Draft Regional Guidebook for the Functional Assessment of High-Gradient Headwater Streams and Low-Gradient Perennial Streams in Appalachi

Review and Evaluation of Reservoir Management Strategies for Harmful Algal Bloom Hydrologic Engineering Center River Analysis System (HEC-RAS) Water Temperature Models Developed for the Missouri River Recovery Management Plan and Environmental Impact Statement

Utilizing Wetlands for Phosphorus Reduction in Great Lakes Watersheds: A Review of Available Literature Examining Soil Properties and Phosphorus Removal Efficienc Evaluation of Wetland Hydrology in Formerly Irrigated Areas

Operational Draft Regional Guidebook for the Rapid Assessment of Wetlands in the Region of Alaska

Organic Waste Diversion Guidance for U.S. Army Installation

Demonstration of Combined Food and Landscape Waste Composting at Fort Leonard Wood, MO: Fort Leonard Wood Installation Strategic Sustainable Plan

Identifying Areas of Potential Wetland Hydrology in Irrigated Croplands Using Aerial Image Interpretation and Analysis of Rainfall Normalit

\section{Sustainable Facilities and Infrastructure}

Demonstration of Antimicrobial Corrosion-Resisting Interior Coating Systems for Military Facilities in Warm, Humid Locations: Final Report on Project F10-ARO 
Focus Area / Document

Demonstration of Thermally Sprayed Metal and Polymer Coatings for Steel Structures at Fort Bragg, NC: Final Report on Project F07-AR1

Estimating Resistance and Resilience of Military Lands Using Vegetation Indices Development of a Predictive Corrosion Model Using Locality-Specific Corrosion Indices

Feasibility Study of Food Waste Co-Digestion at U.S. Army Installations

Effect of Arctic Amplification on Design Snow Loads in Alaska: SERDP RC-243

Assessment of Asphalt Concrete Reinforcement Grid in Flexible Pavement

Summit Station Skiway Cost Analysis

Ground-Penetrating-Radar Profiles of Interior Alaska Highways: Interpretation of Stratified

Fill, Frost Depths, Water Table, and Thaw Settlement over Ice-Rich Permafrost

Matthew Jones House: Recommendations for Treatment

Landscape Evolution of the Oil Spill Mitigation Sand Berm in the Chandeleur Islands, Louisiana

Field Testing and Summary Report for Road 5 (Morris Road) over Road 3 (Toftoy Throughway) at Redstone Arsenal, AL: Contractor's Supplemental Report for Project F09-AR1

Field Testing and Load Rating Report for Bridge No. 4, Composite Grid Reinforcement of Concrete Deck, at Fort Knox, Kentucky: Contractor's Supplemental Report for Project F12-ARO

Field Testing and Load Rating Report for Bridge No. 4, Hybrid Composite Beam Span, at Fort Knox, Kentucky: Contractor's Supplemental Report for Project F12-AR15

Historic American Engineering Record (HAER) Level II Documentation of Launch Complexes 1/2, 3/4, 9/10, 14, and 34 at Cape Canaveral Air Force Station, Florid

Cultural Landscape Analysis of Existing Historic Districts: Picatinny Arsenal, New Jerse

Demonstration of a Liquid-Applied Liner System for Corrosion Protection and Rehabilitation of Wastewater System Structures: Final Report on Project F11-AR24

Character-Defining Features of Contributing Buildings and Structures in the Signal School Campus Historic District at Fort Gordon, Georgi

Corrosion Control of Central Vehicle Wash Facility Pump Components Using Alternative Alloy Coatings: Final Report on Project F09-AR14

Architectural Survey of Laramie Armory, Wyoming Army National Guar

NRHP Eligibility of the Fort Huachuca, Arizona, Elevated Water Tank (Facility 49001) and Reservoir (Facility 22020

Assessing Socioeconomic Impacts of Cascading Infrastructure Disruptions Using the Capability Approach

Cultural Landscape Inventory for Picatinny Arsenal, New Jerse

Demonstration and Validation of a Composite Grid Reinforcement System for Bridge Decks: Final Report on Project F12-AR01

Demonstration of Corrosion-Resistant Hybrid Composite Bridge Beams for Structural Applications: Final Report on Project F12-AR15

Modeling the Fate of Lead from Small Arms Firing Ranges, Fort Jackson, SC

The Department of Homeland Security Supplement to the Environmental Assessment and Management (TEAM) Guide

Understanding the Effects of Infrastructure Changes on Subpopulations: Survey of Current Methods, Models, and Tools

Cultural Landscape Analysis of Existing Historic Districts: Picatinny Arsenal, New Jersey

\section{Sustainable Contingency Basing}

Opportunities for Waste Heat Recovery at Contingency Bases

Assessing Socioeconomic Impacts of Cascading Infrastructure Disruptions in a Dynamic Human-Infrastructure Network

SMART Energy Efficient Deployable Shelters (SEEDS)

Novel Anaerobic Wastewater Treatment System for Energy Generation at Forward Operating Bases: Final Report on Environmental Restoration Project ER-221

Construction Material-Based Methodology for Military Contingency Base Construction: Case Study of Dhaka, Banglades

Machine Classification of Text and the Detection of Dominant Political Narratives

\section{Sustainable Natural Infrastructure}

Geopolymer Soil Stabilization at Sierra Army Depot

Elders Point East Marsh Island Restoration-Monitoring Data Analysis

Two-Dimensional Movement Patterns of Juvenile Winter-Run and Late-Fall Run Chinook Salmon at the Fremont Weir, Sacramento River, CA

Documenting Presence and Movements of Piscivorous Birds along the Illinois River and within the Chicago Area Waterway System

Floristic Quality Index of Restored Wetlands in Coastal Louisiana

User Guidance for Application of TREECS ${ }^{T M}$ and CTS for Environmental Risk Assessment of Contaminants on Department of Defense (DoD) Ranges 


\section{Focus Area / Document}

Page

Lake Aquilla Habitat Survey Hill County, Texas

Review and Synthesis of Evidence Regarding Environmental Risks Posed by Munitions Constituents (MC) in Aquatic Systems

Evaluation of Electromagnetic Induction (EMI) Resistivity Technologies for Assessing Permafrost Geomorphologie

A Species Distribution Modeling Informed Conservation Assessment of Bog Spicebush Synthesizing the Scientific Foundation for Ordinary High Water Mark Delineation in Fluvial System

Autonomous Sea-Ice Thickness Surve

Technology Transfer of Biopolymer Soil Amendment for Rapid Revegetation and Erosion Control at Fort A. P. Hill, Virginia

Image Analysis and Classification Based on Soil Strength

Adaptation Strategies for Training Lands and Ranges at Fort Leonard Wood, MO

Nanomaterial Dispersion/Dissolution Characterization: Scientific Operating Procedure SOP$F-1$

California Least Tern Foraging Ecology in Southern California: A Review of Foraging Behavior Relative to Proposed Dredging Location

Evaluation of 757 Species under U.S. Endangered Species Act Review on U.S. Department of Defense Lands and their Potential Impact on Army Trainin

Assessment of Small Arms Munitions Impacts on Natural Infrastructure in Sensitive Downrange Areas on Military Installations

\section{Green Remediation and Reuse}

Composition of CBRN Decontamination Effluent and Development of Surrogate Mixtures for Testing Effluent Treatment Technologie

Removing Hazardous Materials from Buildings: A Training Curriculum

Testing and Validation Studies of the NSMII-Benthic Sediment Diagenesis Module

Aquatic Contaminant and Mercury Simulation Modules Developed for Hydrologic and Hydraulic Models

Evaluation of Rhizobium tropici-derived Biopolymer for Erosion Control of Protective Berms. Field Study: lowa Army Ammunition Plant

Flexible Reactive Berm (FRBerm) for Removal of Heavy Metals from Runoff Water: ER-1213 Treatability Stud

Impact of Incremental Sampling Methodology (ISM) on Metals Bioavailability

Passive Gamma-Ray Emission for Soil-Disturbance Detection

A Portable Burn Pan for the Disposal of Gun Propellant

Aviation Fuel Ignition and Burn Behavior in Antarctica

Complete Host Range Testing on Common Reed with Potential Biological Control Agents and Investigation into Biological Control for Flowering Rush

Side Channels of the Impounded and Middle Mississippi River: Opportunities and Challenges to Maximize Restoration Potential

CONUS Demonstration Site Selection for Surface Water Characterization in Remote, SparseData Environments: Calleguas Creek Watershed, Ventura County, California

Testing of the KRIA Ionizing Water Treatment System for Waters Contaminated with Diesel, PCBs, and Nutrients (Nitrogen Forms

The Biodiversity Security Index: A New Metric for Benefits from USACE Ecosystem Restoration Projects

Laboratory-Scale Demonstration Using Dilute Ammonia Gas Induction of Alkaline Hydrolysis Treatment of Soil Chlorinated Propanes and Explosives
66

67

68

69

70

70

71

72

72

73

74

75

75

77

78

78

79

79

80

81

82

83

83

84

85

85

86

87

87 


\section{REPORT DOCUMENTATION PAGE}

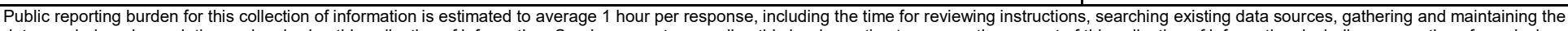

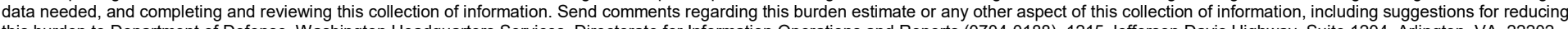

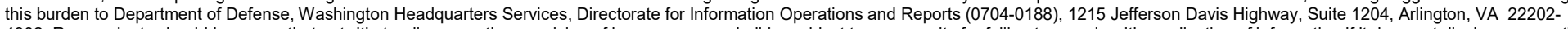

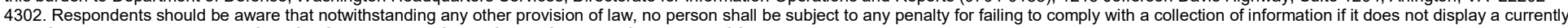
valid OMB control number. PLEASE DO NOT RETURN YOUR FORM TO THE ABOVE ADDRESS.
1. REPORT DATE (DD-MM-YYYY)
04/04/2018
2. REPORT TYPE
Final

\section{TITLE AND SUBTITLE}

Sustainability-Related Publications Calendar Years 2016 - 2017

\section{AUTHOR(S)}

Franklin H. Holcomb, Patrick N. Deliman, and David B. Ringelberg

\section{DATES COVERED (From - To)}

5a. CONTRACT NUMBER

5b. GRANT NUMBER

\section{5c. PROGRAM ELEMENT}

5d. PROJECT NUMBER

611102AH68

5e. TASK NUMBER

\section{5f. WORK UNIT NUMBER}

\section{PERFORMING ORGANIZATION REPORT} NUMBER

U.S. Army Engineer Research and Development Center (ERDC)

Construction Engineering Research Laboratory (CERL)

PO Box 9005,

Champaign, IL 61826-9005
ERDC SR-18-1

\section{SPONSORING / MONITORING AGENCY NAME(S) AND ADDRESS(ES)}

U.S. Army Engineer Research and Development Center (ERDC)

Construction Engineering Research Laboratory (CERL)

PO Box 9005

Champaign, IL 61826-9005
CEERD-CZT

11. SPONSOR/MONITOR'S REPORT NUMBER(S)

\section{DISTRIBUTION / AVAILABILITY STATEMENT}

Approved for public release; distribution is unlimited.

\section{SUPPLEMENTARY NOTES}

\section{ABSTRACT}

The Center for the Advancement of Sustainability Innovations (CASI) was established by the U.S. Army Engineer Research and Development Center (ERDC) as a new capability in 2006 hosted at the Construction Engineering Research Laboratory (CERL) in Champaign, IL. CASI was established with the goal of focusing the value of ERDC expertise, technologies, and partnerships toward helping the U.S. Army Corps of Engineers (USACE), the Army, and the Department of Defense (DoD) achieve more sustainable facilities and operations. CASI provides the military with capabilities that enhance national security by more effectively using limited resources and improving coordination and partnerships with host communities and stakeholders in the United States and around the globe. CASI teams strive to measure sustainability innovations against the Triple Bottom Line of mission, environment, and community. CASI focuses on cost savings, innovation, collaborative solutions, and continuous learning - which directly link sustainability to Army policy and guidance documents including Army Installations 2025; Installations, Energy and Environment Strategy 2025; Army Environment, Safety, \& Occupational Health Strategy 2025; and Energy Security and Sustainability (ES2) Strategy. Note that this "summary of sustainability-related publications" incorporates descriptions of work related to the theme of sustainability conducted under many ERDC programs as well as CASI.

\section{SUBJECT TERMS}

CASI, Center for the Advancement of Sustainability Innovations, Army, environment, sustainability

\begin{tabular}{|c|c|c|c|c|c|}
\hline 16. SECURITY C & IFICATION OF: & & 17. LIMITATION & 18. NUMBER & 19a. NAME OF RESPONSIBLE PERSON \\
\hline $\begin{array}{l}\text { a. REPORT } \\
\text { Unclassified }\end{array}$ & $\begin{array}{l}\text { b. ABSTRACT } \\
\text { Unclassified }\end{array}$ & $\begin{array}{l}\text { c. THIS PAGE } \\
\text { Unclassified }\end{array}$ & SAR & 98 & $\begin{array}{l}\text { 19b. TELEPHONE NUMBER } \\
\text { (include area code) }\end{array}$ \\
\hline
\end{tabular}

